\begin{tabular}{|c|c|c|c|c|c|c|}
\hline \multirow{4}{*}{ Impact Factor: } & ISRA (India) & $=3.117$ & SIS (USA) & $=0.912$ & ICV (Poland) & $=6.630$ \\
\hline & ISI (Dubai, UAE & $=0.829$ & РИНЦ (Russia & $=0.156$ & PIF (India) & $=1.940$ \\
\hline & GIF (Australia) & $=0.564$ & ESJI (KZ) & $=8.716$ & IBI (India) & $=4.260$ \\
\hline & JIF & $=1.500$ & SJIF (Morocco & $=5.667$ & OAJI (USA) & $=0.350$ \\
\hline
\end{tabular}

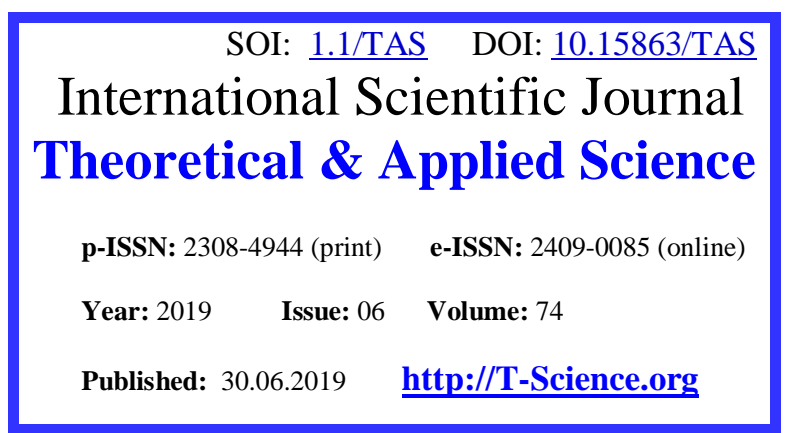

SECTION 31. Economic research, finance, innovation, risk management.

UDC 685: 54335.17

\section{QR - Issue}
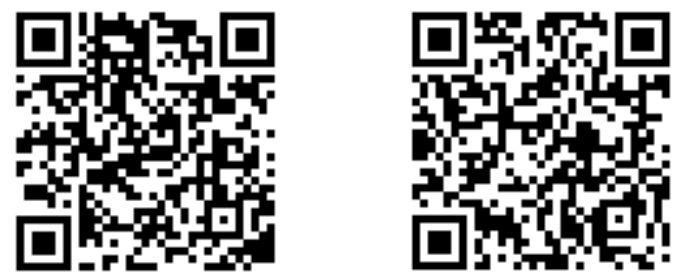

Artur Alexandrovich Blagorodov Institute of Entrepreneurship and Service sector (branch)

DSTU

bachelor, g. Shakhty

blaghorodov@list.ru

Dmitri Olegovich Bordukh

Institute of Entrepreneurship and Service sector (branch)

DSTU

bachelor, g. Shakhty

bordukh95@bk.ru

Angelina Vladimirovna Kopylova Institute of Entrepreneurship and Service sector (branch)

DSTU

bachelor, g. Shakhty angelinakopylova22121999@mail.ru

Vladimir Timofeevich Prokhorov ISOP (f) DGTU

Doctor of technical sciences, professor, professor of the department "Designing, technology and design", Shakhty prohorov@sssu.ru

Igor Mikhailovich Maltsev Institute of Entrepreneurship and Sevice sector (branch)

DSTU associate Professor, Ph. D.-m H., g. Shakhty

Natalia Vassilievna Tikhonova Kazan national research technological University Doctor of technical sciences, professor

Kazan, Republic of Tatarstan

\title{
ON THE EFFECTIVENESS OF COMPREHENSIVE SURVEY RESPONDENTS TO FORMATION WITH DIGITAL PRODUCTION DEMAND PRODUCT RANGE
}

Abstract: in the article, the authors with the help of questionnaires developed by them, conducted a survey among children, parents, manufacturers and buyers in specialized stores selling children's shoes, processed them with the help of software and with a high degree of reliability formulated a popular assortment of children's shoes, guaranteeing the child's foot comfort convenience against the background of its attractiveness and preventing the formation of pathological deviations in it: transverse and longitudinal flat feet, clubfoot and other defects.

Key words: respondents, the questionnaire survey, the range of footwear, the demand for the product, the coefficient of concordance, reliability, competence, coherence, comfort, attractiveness, safety.

Language: English 


\begin{tabular}{|c|c|c|c|c|c|c|}
\hline \multirow{4}{*}{ Impact Factor: } & ISRA (India) & $=3.117$ & SIS (USA) & $=0.912$ & ICV (Poland) & $=6.630$ \\
\hline & ISI (Dubai, UAE & $=0.829$ & РИНЦ (Russia & $=0.156$ & PIF (India) & $=1.940$ \\
\hline & GIF (Australia) & $=0.564$ & ESJI (KZ) & $=8.716$ & IBI (India) & $=4.260$ \\
\hline & JIF & $=1.500$ & SJIF (Morocco & $=\mathbf{5 . 6 6 7}$ & OAJI (USA) & $=0.350$ \\
\hline
\end{tabular}

Citation: Blagorodov, A. A., Bordukh, D. O., Kopylova, A. V., Prokhorov, V. T., Maltsev, I. M., \& Tikhonova, N. V. (2019). On the effectiveness of comprehensive survey respondents to formation with digital production demand product range. ISJ Theoretical \& Applied Science, 06 (74), 735-767.

Soi: http://s-o-i.org/1.1/TAS-06-74-87 Doi: crossef https://dx.doi.org/10.15863/TAS.2019.06.74.87

\section{Introduction}

To confirm the assessment of production efficiency generated by footwear companies analyzed the annual results of the company for the production of both male and children's and women's footwear assortment.

These calculations indicate that at $100 \%$ of sales of shoes in a specified time period covered not only the cost of production and sales, but also remains a profit of 3697.4 thousand. Rub. This confirms the effectiveness of the company, as well as the correct choice of marketing and assortment policy. Since the profitability of the product is $14.9 \%$.

To prove our proposals, they were confirmed by the results of the calculation of technical and economic parameters of its activities with the software developed by us, allowing you to choose not only the volume of production, which would be guaranteed by the manufacturer to obtain economic benefit, which evaluates its comprehensive performance indicator (EFC) will seek to its maximum value, namely, to one [1], but also to ensure its implementation in the markets of the Southern Federal District and the North Caucasian Federal District regions. [one]

The greatest interest is the fact that the direct injection technology on the bottom of shoes today, but what is especially important, and tomorrow will be the most effective for the production of the entire product range. This is possible because today the chemical industry offers manufacturers for direct casting bottom of shoes polymer compositions, creating conditions to use the entire possible list of materials for shoe uppers and thus guarantee consumers high quality, matching the direction of fashion, function and affordability and to ensure it competitive with similar footwear leading foreign companies, forcing them to our markets and creating a shoe priorities, ie import substitution.

\section{Main part.}

The global market for footwear is estimated at 260 billion., The rate of growth over the last 5 years was $3.5 \%$. China, the US and India are the largest footwear market. Specific footwear consumption in Russia is much lower than in developed countries. China is the largest exporter of the shoe and serves all major world markets.

The main drivers of growth of the Russian footwear market - increase in the share of consumption of footwear per person, and decrease in the average cost of a pair. Russia lags far behind in the footwear consumption in developed countries ( 3 pairs per year against Russia 5-6 7-8 in Europe and in the US). By 2025, this figure could rise to 4 pairs per person. The average price of a pair of 2025 may increase from 1,800 to 2,500 rubles in current prices. In 2017 footwear consumption in Russia is estimated at 0.81 trillion. rub.

By analogy with the clothing industry, the main factors determining competitive advantage products are available and increase in domestic raw hides, access to cheap and productive labor, access to auxiliary materials and functional components of the shoe (insoles, pads, fittings, etc. D. ), as well as access to markets. [2,3]

The share of labor costs in footwear production slightly lower than in the clothing, but the main problem today and tomorrow for the Russian shoe manufacturers is the difficulty of access to auxiliary materials and functional components, the absence of domestic manufacturers of high-efficiency equipment for the manufacture of footwear.

The cost price of footwear production in Russia is 1.5 times higher than in China, and the cost of components is $35 \%$ more expensive, because they are imported from China at higher prices due to low order volumes, the cost of labor in Russia in 2 times more expensive than in China

Effective opportunities to reduce costs by reducing delivery times in the shoe production is possible only by providing quick access to materials and components, but the need to import them from Asia can not achieve the advantages of Russian producers on terms. Using natural skin Russian production and increase in the production of leather footwear will reduce delivery times and partly expensive components. Another one of the possible tools for solving problems with the components may also be the creation of purchasing alliances - the consolidation of orders for components can reduce their costs by $20 \%$. By analogy with the segment of technical textiles, footwear production in the world is developing in the form of innovation centers / industrial parks, with many niche players.

The development strategy of footwear production - consolidation and development through innovation centers. The main directions of the state policy, other than the above to create equal competitive conditions in the footwear market [5]

- support for the establishment of industrial infrastructure in the framework of innovation centers:

- support for the creation of innovative industrial centers of the largest shoe manufacturers and SMEs in order to achieve economies of scale and synergies;

- support for the modernization of production to increase productivity;

- providing favorable access for producers to the functional components: 


\begin{tabular}{|c|c|c|c|c|c|c|}
\hline \multirow{4}{*}{ Impact Factor: } & ISRA (India) & $=3.117$ & SIS (USA) & $=0.912$ & ICV (Poland) & $=6.630$ \\
\hline & ISI (Dubai, UAI & $=0.829$ & РИНЦ (Russia & $=0.156$ & PIF (India) & $=1.940$ \\
\hline & GIF (Australia) & $=0.564$ & ESJI (KZ) & $=8.716$ & IBI (India) & $=4.260$ \\
\hline & JIF & $=1.500$ & SJIF (Morocco & $=5.667$ & OAJI (USA) & $=0.350$ \\
\hline
\end{tabular}

- Support the creation of purchasing alliances to supply functional components;

- Supports partial localization of component manufacturers within the shoe innovation centers.

The total volume of domestic footwear production in Russia by 2020 could reach 310-340 bln. Rubles (in prices of manufacturers), which would correspond to $60 \%$ localization. In this case, up to $20 \%$ increase in production of footwear and provide special protective products. Estimated amount of investment required in the sector -. 95-120 billion rubles can be up to $30-50$ thousand new jobs.. The development of the garment industry will add $0.05 \%$ to GDP and provide $36-58 \mathrm{bn}$. Rub. tax revenues. The combined effect of the development of garment and footwear production in Russia will amount to $0.11 \%$ of GDP $(0.06 \%$ effect on the development of garment production, $0.05 \%$ - of the shoe). The total volume of investments required - 180-270 billion rubles.. 160200 thousand. New jobs will be created. The expected tax revenue in 2025 - 124-162 billion rubles.

For strategic management of the production of marketable goods should:

- to study the demand for manufactured shoes and together with marketing experts, production and logistics to develop solutions for the timely removal of models with the production and updating of the range;

- explore the markets in different regions, and different forms of organization of sales, study of potential buyers;

- examine customer reaction to the experimental batches of footwear in specialized stores;

- together with the economic planning department to develop the situation on their own pricing policy; study the impact of the prices for the implementation for the various regions;

- to develop the wholesale buyers incentive policy for volume orders, long-term contracts, etc .;

- predict the possible changes in the situation and to develop solutions for the strategy of behavior in the new environment;

- to coordinate the conflicting requirements of production and marketing; organize and study the effectiveness of advertising.

You can imagine yourself a manager of CJSC "Donobuv" which opened a new shop and chose a new strategy for the production and promotion of footwear in the Southern Federal District and the North Caucasian Federal District. Here's what can happen. The main markets for the sale of products of JSC "Donobuv" today is the Moscow and Moscow Region. The raw data that forms the facility manager for the company board of directors - is to prepare a draft of the future strategy for the selection of a certain type of shoe, such as: [6.7]

- make expensive shoes for the target audience with high income (item A);
- specialize in producing an inexpensive shoe to the target audience with earnings-subsistence (product B);

- to produce cheap shoes for socially protected layers with earnings below subsistence level (item C). [2]

In the future, the following scenarios of development of the external environment, the probability of which is estimated the company's management as follows: increase in purchasing power (scenario S1, the probability of occurrence - 0.2); immutability of purchasing power of the population and the impact of foreign competitors (S2 scenario, the probability of occurrence - 0.5 ); decrease in purchasing power due to inflation growth at constant competition (S3 scenario, the probability of occurrence - 0.3).

For more information, to make the necessary calculations:

- a living wage - 9691 rubles.

- daily issue - 576 pairs of shoes;

- number - 100 people, who are engaged in the release of 576 pairs of shoes a day.

- with a working week of 5 days, the total number of operating days in the year - 250 days;

- monthly production of footwear - 12,000 pairs;

- the annual production of 144,000 pairs of shoes.

We assume that the average cost of one pair of shoes at constant purchasing power (S2 scenario) will be characterized by the following values: the price of a pair of expensive shoes for the target audience with high income of 5 thousand rubles .; the price of a pair of shoes for the target audience with earnings above the minimum subsistence level - 2 thousand rubles .; the price of a pair of cheap shoes for socially protected layers with earnings below subsistence level - 1 thousand rubles..

The total sales volume of footwear at constant purchasing power ( $\mathrm{S} 2$ scenario) will be considered for the audience:

- the implementation of expensive shoes for the target audience with high income - 60 million rubles.. per month;

- the implementation of the shoe to the target audience with earnings above the subsistence minimum - 24 million rubles.. month;

- the implementation of cheap shoes for socially protected layers with earnings below the subsistence minimum - 12 million rubles.. per month.

For the target audience with the growth of purchasing power (S1 scenario), the price of a pair of expensive shoes will be 9 thousand rubles, the price of one pair of shoes for the target audience with earnings above the minimum subsistence level -.... 5 thousand rubles, the price of one pair of shoes for unprotected layers - .. 2 RUR, with low purchasing power (S3 scenario), the price of one pair of shoes is expensive 2.5 th RUB, the price of one pair of shoes for the target 


\begin{tabular}{|c|c|c|c|c|c|c|}
\hline \multirow{4}{*}{ Impact Factor: } & ISRA (India) & $=3.117$ & SIS (USA) & $=0.912$ & ICV (Poland) & $=6.630$ \\
\hline & ISI (Dubai, UAI & $=0.829$ & РИНЦ (Russia & $=0.156$ & PIF (India) & $=1.940$ \\
\hline & GIF (Australia) & $=0.564$ & ESJI (KZ) & $=8.716$ & IBI (India) & $=4.260$ \\
\hline & JIF & $=1.500$ & SJIF (Morocco & $=5.667$ & OAJI (USA) & $=0.350$ \\
\hline
\end{tabular}

audience with earnings above subsistence $-\ldots . .1$ th RUB, the price of one pair shoes for unprotected layers - 500 rubles.

For each of the scenarios under consideration calculated the volume of sales of shoes per month. We carried out a calculation of the sum of the mathematical expectations of the realization volume taking into account the likelihood of the three scenarios. Management companies based on their experience or analysis (intuitively), estimate the probability of occurrence of a particular situation, [3].

Separately for each strategy is determined by the sum of the mathematical expectations of the sales volumes of the product of footwear sales volume per month in the implementation of each scenario on its probability.

On the calculation of the amount of the expectation of sales volume, the maximum sales volume gained expensive footwear production strategy for the target audience with high income.

Summing up the information obtained as a result of the study, formulated as a block diagram the formation of mentality. The proposed structuring can be used when planning range for industrial and SFD NCFD regions. It was only in the relationship of all the factors considered above can be argued about the high stability of the financial performance of the shoe enterprises regions of the Southern Federal District and North Caucasus Federal District, united in the Innovation Center.

Range of children's shoes must focus on customers with different income levels, for this in the production of shoes you want to use the skin to high quality top, such as a kid or a cheaper - pigskin chrome-tanned leather, shoes that can be worn on the "exit", and came home, take to the legs of the child rested.

Also, the development of the range should be considered and that the girls in the Southern and North Caucasus Federal District is born more than boys, so girls shoes should be produced at a higher level than the shoes for boys.

If the shoe manufacturers for children will be guided by the recommendations of the authors of all the above, the buyers will have the opportunity, depending on their financial situation, to give preference to products of a particular price category made taking into account the climatic characteristics of the SFD and generic characteristics of its population.

Main place among the attributes of any enterprise takes the name of the company goes public. We know the company not by a legal phrase that is enshrined in the relevant registration documents (yes it is unknown to wide range of customers), and on the brand's products. Thus, the rare consumer knows that the shoes of the Trading House "Squirrel" - is Ralf Ringer. Producers SFD and North Caucasus Federal District mostly name (brand name) is absent.
There are several methods of forming the name, logo and trademark of birth.

The most common way - the choice of a proper name. Typical for the fashion houses (class "luxury" goods) - the founder of the company name CHRISTIAN DIOR, CHANEL, GIVENCHY, YVES SAINT LORAN etc. Unique taste, bright style of expressing the personality of artists in their works, later asking things issued under this name, high status. This technique has become necessary if the company creates an individual or family and you want to emphasize the personal role of the owner, and build on its reputation and the reputation of the company's policy. With this approach, the role of the individual is invaluable. Last name must be the guarantor of the quality of products and business management. Accordingly, if the owner of the image not just directly related to the company's image, but also has the primary emotional burden. [8]

Another way - the commercial name of the company is based on the acronym made up of the first letters of the official title. This achieves conciseness name and the ease of pronunciation and memorizing respectively. Can clearly be seen that it is an abbreviation - a great tool for getting a logo - the company LVMH / Louis Vuitton Moet Hennessy /. The same method of recourse companies positioning their products in the class of «Bridge better», representing the second line of the famous houses; in the title is a link to the artist's name, associated with its line of luxury "souture» and "preta - porte de lux»" and an abbreviated reduction. For example, Mani (Armani), DKNY (Donna Karan New Your), CK Jeans (Calvin Klein).

Second - much less common in the fashion industry - education it is the United root fragments of a few words, is not necessarily present in the company's name. But in this case, the desirable association with the profile of the company. The requirement, like any other group names and unusual euphony.

The third way - the formation of new words, do not like the existing meaningful words, but is associated with positive concepts. Most often, the positioning of these companies is connected with the class bridge middle, bridge low and moderate mass clothing class and buget.

For example, the name of the company "Skorokhod" - the production of children's footwear. Saying "Skorokhod" can provoke association with a rapid movement, and the children love to run, they need a high-quality and reliable shoes.

Another example, the name of the company MEXX. Close association does not occur, but the name of the modern and succinctly. It is consistent with the positioning of the enterprise - clothes for the young of the perfect combination of "style, price and quality." 


\begin{tabular}{|c|c|c|c|c|c|c|}
\hline \multirow{4}{*}{ Impact Factor: } & ISRA (India) & $=3.117$ & SIS (USA) & $=0.912$ & ICV (Poland) & $=6.630$ \\
\hline & ISI (Dubai, UAI & $=0.829$ & РИНЦ (Russia & $=0.156$ & PIF (India) & $=1.940$ \\
\hline & GIF (Australia) & $=0.564$ & ESJI (KZ) & $=8.716$ & IBI (India) & $=4.260$ \\
\hline & JIF & $=1.500$ & SJIF (Morocco & $=5.667$ & OAJI (USA) & $=0.350$ \\
\hline
\end{tabular}

It should be noted a great number of names that exploit the Latin alphabet for writing their names. It seems to us that the roots of this phenomenon lie in the statements - the legacy of the Soviet era "in Russian fashion, no!", "Domestic, so bad." Accordingly, the domestic enterprises, on the release of the first post-Soviet market, have been forced to masquerade as foreign manufacturers. Gregory, Gloria Jeans, Climona, Vereteno, Festival, ZARINA here are numerous examples of this strategy in choosing the name of the company.

The fourth method is the logo. Purpose of the logo in the fashion industry - this instant brand awareness. Logo - a symbolism that replaces the name or is a graphic interpretation. Interestingly, in the world of fashion logo has become so much a part of the design of clothing and footwear.

The logo is the identification mark for the uninitiated crowd, which to these letters will know how much worth this or that subject. This cheat sheet for those who can not determine the silhouette of Dolce \& Gabbana, Christian Dior and Ferré. If the general trend towards ever greater visualization, font graphics - all kinds of pointers. Plates and labels - have come to play an increasingly important role. Logo as the replacement text, it becomes the ideal solution if you need to combine the decorative and informative.

In addition to its primary function - commodity stamp - plays the role of the decorative. This is a natural result plexus fashion - industry and advertising.

Here are the reasons: first - Industrial - fashion on the text as a decorative element. The second - the fashion for democracy in the clothing, ie Crisis awareness of styles, subject binding to a specific brand. Third - about advertising. This offset a framework "expensive - cheap": it is the design of the product and not the quality of the materials used or the amount of manual labor is increasingly defines customer value. Glut of the advertising information enables logos become part of the decor.

Logo becomes more imaginative and emotional. And you can play with the images, placing it where it was hitherto unthinkable. Thus today, buyers of fashionable footwear made advertising media brands due to general logotypization.

The main thing - matching emotions caused by advertising the product, brand image and design of the products themselves.

After all, the subject of promotion should be specific, simple, clear and bright, that is, advertising. At the same time bear to read emotionally charged image. So, without a logo can not do.

Verbal logo - name written in a certain way, it is the most commonly used attributes, forming in the minds of consumers first emotional connection to the company's image. A certain way of verbal image of the logo to become a distinctive and original feature of the enterprise.
Another important trend in the enterprise to promote their brand is the design of the place of sale in the trade environment. Where you meet the following requirements:

convenience of the location for a specific target audience (Via Corso - street boutiques in Milan, and the area of Il Duomo department store La Rinaschente - both conveniently located in the center of Milan, but the consumer in these different commercial spaces). as it has been already mentioned, like community boutiques shoe trade will be created in Russia on the basis of the factory "Paris Commune". the need for such a base there in the Southern and North Caucasus Federal District - it will organize the market regions;

- observance of the concept of representation image of the product, ie thoughtful principles of presenting product features to meet the expected motivation of its consumer choice;

- figuratively targeted solution environment must be tailored to the type of consumer. to be implemented opportunity to try on shoes, get the seller advice;

- Wednesday should have to stay and to provoke interest in the products. in the shop may sound pleasant music, every visitor must be given a booklet with brand shoes;

- the figurative decision of the environment must be raised above the commonplace, to create a sense of "events", "chosen", "opportunities completeness" or "availability". the company may introduce a system of discounts for re-attract consumers;

- to support the additional range of services within the terms of spending time and cultural interests of the consumer. the customer can be offered as a gift cream just bought shoes or other clothing accessory was presented with the manufacturer's logo. [four]

Consumers in the market does not appear monolithic community. When buying shoes, they are guided, first of all type of footwear and price.

For example, when choosing a buyer of women's boots into account the seasonality of the shoe, its age features and type of work, it is important attributes will then be the appearance of the shoe: matching fashion trends, colors, materials, top and bottom, as well as a constructive solution models. Buyers also prefer brand. It is an offer of shoes to the consumer in specialty stores or departments will provoke an increase in sales in an uncertain demand. And if we seller, having a well thought-out principles of presenting advantageous properties of each design women's boots, and guessing the mood and the possibility of women customers at their reasoned matters when choosing a model will be able to realize this same desire, in any case, the buyer will leave satisfied that his interests are fully satisfied and he himself,

The elderly love comfort and coziness. Both the seller and the buyer - the representative of the 


\begin{tabular}{|c|c|c|c|c|c|c|}
\hline \multirow{4}{*}{ Impact Factor: } & ISRA (India) & $=3.117$ & SIS (USA) & $=0.912$ & ICV (Poland) & $=6.630$ \\
\hline & ISI (Dubai, UAE & $=0.829$ & РИНЦ (Russia & $=0.156$ & PIF (India) & $=1.940$ \\
\hline & GIF (Australia) & $=0.564$ & ESJI (KZ) & $=8.716$ & IBI (India) & $=4.260$ \\
\hline & JIF & $=1.500$ & SJIF (Morocce & $=5.667$ & OAJI (USA) & $=0.350$ \\
\hline
\end{tabular}

beautiful half - of course, turn their attention to the model, if it is nice to be worn in the snowy winter, since it must be made of soft nap leather - suede and have a molded sole with large tread, as will very comfortable and provide them comfort at any time during her socks .. at the same time it must be affordable.

Business woman, aged 45 and 45 and residing in the vanity, of course, will give preference to models made of natural materials, low-heeled, low-key accessories, creating imposed the comfort in their daily lives, while emphasizing their image and social status.

The appearance in the cabin or in a regular store or a high school student fashionistas immediately attract the attention of interior seller who wants to offer them only the original model on the high heels especially with overhead straps, decorated holnitenami and secured at the top and bottom of the shaft. Fashionista will be pleased that bought what she wanted, and high school will be satisfied buying more because she was sure that this purchase will surprise her friends and for her - this is the most important argument in favor of buying.

Seller always easy if there was a "socialite" in the store, as it always favors only innovations or exclusive models. These its ambitions can be met as a model at the expense of originality, and at the expense of constructive solutions, also due to the selected materials and decorations in the production of the model itself. .

Girls who love the strictness, but at the same time, the originality, the seller is required to propose a model in which combines two materials of colors and textures and details, perforated, draped in the ankle, give it unusual.

And the price should not be very "bite", which is also not a few important argument in favor of buying. These are our fancy, peeped into the life and work very effectively to the demand justified and have a right to be, because the ability to present their products to work with the consumer competent marketing approach form the popularity of the boutique, shop or salon with customers and provide them with strong consumer demand. Ultimately designed principles of presenting the properties of the product, the choice of the consumer, the right design boutiques and shop windows - all this will help to have a significant impact on the effective results of their work in the same fully applies to the children's range ..

Assortment - the problem of specific products, their individual series, determining the relations between "old" and "new" products, products for single and serial production, "High" and "normal" goods, materialized goods or licenses and "know-how". When forming the price range there are problems of quality, warranty, service, whether the manufacturer is going to play a leadership role in the creation of new types of products or forced to follow other manufacturer

The formation range precedes the development of enterprise product line concept. It is aimed to build an optimum assortment structure, commodity supply, with a basis accepted, on the one hand, the consumer demands of certain groups (segments), and with another - the need to ensure the most efficient use of enterprise commodity, technological, financial and other resources in order to manufacture products with low costs. [5]

Assortment concept is expressed in the form of a system of indicators characterizing the possibility of optimal development of the production range of this type of goods. These indicators include: the diversity of species and varieties of goods (taking into account the typology of consumers); the level and frequency of updating of assortment; level and the ratio of the price of goods of this type, and others.

forming range includes the following main points: [9]

- identifying current and future customer needs, analysis of ways to use the features of the footwear and consumer behavior in the relevant market;

- Assessment of the existing analogue competitors;

- critical evaluation of products now manufactured in the same range as in items 1 and 2, but with the position of the buyer;

- issues, what products should be added to the range, and which are excluded from it because of changes in the level of competitiveness; whether to diversify production at the expense of other areas of the enterprise production beyond its existing profile.

- Consideration of proposals for the creation of new models of shoes, the improvement of existing ones;

- Development of specifications for new or improved models in accordance with customer requirements;

- studying possibilities of production of new or improved models, including price issues, cost and profitability;

- testing (testing) Shoe considering potential consumers in order to determine their admissibility on the basic parameters;

- Develop specific recommendations for manufacturing companies about the quality of units, style, price, name, packaging, service, etc. in accordance with the results of tests carried out to confirm the acceptability of the product characteristics or the necessity of predetermining the change;

- Evaluation and revision of the entire range. [6]

Planning and assortment management - an integral part of marketing. Even a well-designed marketing and advertising plans will not be able to neutralize the consequences of mistakes made earlier in the planning range. 


\begin{tabular}{|c|c|c|c|c|c|c|}
\hline \multirow{4}{*}{ Impact Factor: } & ISRA (India) & $=3.117$ & SIS (USA) & $=0.912$ & ICV (Poland) & $=6.630$ \\
\hline & ISI (Dubai, UAI & $=0.829$ & РИНЦ (Russia & $=0.156$ & PIF (India) & $=1.940$ \\
\hline & GIF (Australia) & $=0.564$ & ESJI (KZ) & $=8.716$ & IBI (India) & $=4.260$ \\
\hline & JIF & $=1.500$ & SJIF (Morocco & $=5.667$ & OAJI (USA) & $=0.350$ \\
\hline
\end{tabular}

The optimum range of the structure should ensure maximum return on the one hand and sufficient stability of the economic and market indicators (eg sales volume), on the other hand.

Achieving the highest possible profitability is ensured by continuous monitoring of economic indicators and timely decisions on the adjustment range.

Stability of marketing performance is ensured, first of all, by continuously monitoring the market situation and timely reaction to changes, and even better the adoption of pre-emptive action.

However, , it is important that different products were not too many. For the majority of Russian companies, the potential for optimization of the range is still laid in a considerable reduction of the product range. Too large assortment of bad effect on economic performance - there are many positions that are on the volume of sales can not go even to break even. As a result, the overall profitability drops sharply. Only exception of unprofitable and low-profit products from a range of companies can give an increase in the overall profitability of $30-50 \%$.

Thus, a wide range of spray force, makes it difficult to offer customers competent good (even the sales staff are not always able to explain the difference between a particular position or name), dispels the attention of end users.

It is appropriate to recall the psychology of perception of the information. The reality is that the average person is able to simultaneously absorb no more than 5-7 (rarely up to 9) of semantic constructs. Thus, the person making the choice, first selects the best 5-7 options on the basis of the same number of criteria. If the seller offers a large number of selection criteria, the buyer begins to feel uncomfortable and self-eliminates insignificant, from his point of view, the criteria. The same thing happens when you select the actual product. Now imagine what happens when a man in front of a hundred almost indistinguishable (for him) of the goods, and he needs to buy one. People behave in such a situation as follows: or do refuse to buy, so as not being able to compare a number of options, or they prefer what is already taken (or that sounds familiar). There is another category of people (about 7\%), lovers of novelties, which on the contrary will choose something that has not yet been tried.

Thus, from the customer's perspective (for relaxing the selection of measurable perception embodiment) range should consist of no more than 57 groups, 5-7 of names, i.e., the entire range in terms of perception optimally should consist of 25 - 50 titles. If the names of more than an objective, the output is only further classification.

It is generally accepted that a wide range of customer needs. This very wide range of often referred to even as a competitive advantage. But in fact it turns out that for a wide range of manufacturer - it's hundreds of types of products, and for the consumer 7 titles have more than enough.

Consequently, the consumer need not wide range and variety required for it. [7]

If the company professes approach a wide range, it is sufficient to carry out sales analysis, look at the statistics, to make sure that the sales leaders are $5-10$, on the strength of $15 \%$ of names, all other positions are sold very little demand for them is insignificant, although costs differ little from cost of sales leaders. The situation turns out, when several items of "feeds" the whole wide range of businesses. And this is not always justified in terms of the completeness of the range (the favorite argument of sellers), that is, the presence of different items to cover the maximum possible options customer needs. In practice, it turns out that the fullness is completely ensured, even if the existing range of cut twice and even three times. The main thing in this case correctly classify all the goods and to ensure that to an assortment of products were submitted from every possible group that classification. And the more reason for the classification of the company will be able to allocate, the more balanced will be the decision. Thus, the classification of goods can be meet customer needs, according to the functional purpose of the goods, for the benefit for the company. [10]

Of particular importance in this situation is the role played by certain range of positions. To this end, the products can be classified into the following groups:

A - main product group (which bring the basic gain and are in the stage of growth);

B - supports groups of goods (goods that stabilize sales revenues and are in a stage of maturity);

In - a strategic group of products (goods, to ensure future profit of the company);

D - the tactical group of products (goods, intended to encourage the sale of the main product group and are at the stage of growth and maturity);

D - developed by a group of goods (goods that are not present on the market, but are ready to exit the market);

E - products, leaving the market (which are not profitable and should be removed from the production output from the market). [8-9]

After that, it is necessary to determine the share of each group in the total volume of production. For a sustainable situation of the company in the range of structure: a group of products A and B should be not less than $70 \%$.

Thus, this makes it possible to evaluate the available assortment set in the company and by relating it to make a profit, to assess the correctness of assortment planning, its balance.

In addition, not always increase product groups, bringing the main income, will increase the company's profits. It is important to pay attention to the rest of 


\begin{tabular}{|c|c|c|c|c|c|c|}
\hline \multirow{4}{*}{ Impact Factor: } & ISRA (India) & $=3.117$ & SIS (USA) & $=0.912$ & ICV (Poland) & $=6.630$ \\
\hline & ISI (Dubai, UAI & $=0.829$ & РИНЦ (Russia & $=0.156$ & PIF (India) & $=1.940$ \\
\hline & GIF (Australia) & $=0.564$ & ESJI (KZ) & $=8.716$ & IBI (India) & $=4.260$ \\
\hline & JIF & $=1.500$ & SJIF (Morocco & $=5.667$ & OAJI (USA) & $=0.350$ \\
\hline
\end{tabular}

unsold goods (which it will increase the possibility of its further implementation).

Planning of production volumes - one of the important problems of assortment policy. The economy is widely used to predict future costs and revenues on the basis of calculation of the cost of production of variable costs. The essence of this method lies in the fact that the company costs are divided into fixed and variable depending on the degree of their response to changes in the scale of production.

The basis of fixed costs is the cost associated with the use of fixed assets (fixed capital). These include the depreciation costs of fixed assets, lease of industrial premises, as well as salaries of administrative personnel, social contributions of the staff. The basis of the variable cost is the cost associated with the use of working capital (working capital). These include the costs of raw materials, fuel, wages of production workers and deductions for their social needs.

It should be emphasized that the total fixed costs, as a constant and not dependent on the volume of production, are subject to change under the influence of other factors. For example, if prices rise, the total fixed costs are also increasing.

for covering the value calculation method provides for the calculation only the variable costs associated with the production and sale of a unit of production. It is based on calculation of the average variable costs and average value of the coating, which is the gross margin and can be calculated as the difference between the cost of production and the sum of the variable costs. Limited only variable costs of production cost simplifying regulation, planning, control due to sharply reduce the number of cost items. The advantage of this method of accounting and costing is also a significant reduction in complexity of accounting and its simplification.

When applying the calculation method of the value appropriate to use coating parameters such as coating amount (profit margin) and the cover factor.

The amount of coverage (profit margin) is the difference between the sales proceeds and the sum total of variable costs. The amount of coverage can be calculated in a different way - as the sum of fixed costs and profit. The calculation of the amount of coverage to determine the means of the enterprise, received her at the realization of the products in order to offset the fixed costs and profit. Thus, the amount of coverage shows the overall level of profitability as the entire production, as well as individual products: the higher the difference between the selling price of the product and the amount of the variable costs, the higher the amount of its coverage and the level of profitability.

The coverage ratio is called the share of the coverage of the revenue from the sale of the share or the average value of the coating in the price of goods.
It is also important to determine at what sales volume will pay off gross costs of the enterprise. To do this, you need to calculate the breakeven point at which revenues are received or the volume of production, to ensure coverage of all costs and zero profit. Those. revealed a minimal amount of revenue from sales of products in which the level of profitability will be more than $0.00 \%$. If the company earns revenues greater than that which corresponds to the point of break-even, so it works profitably. Comparing these two values of revenue, it is possible to estimate the reduction in allowable revenue (sales volume) without any danger of being at a loss. Revenue corresponding to the breakeven point, called a threshold revenue. The volume of production (sales) at breakeven threshold is called the volume of production (sales).

To assess whether the actual revenue exceeds the revenue providing breakeven, necessary to calculate the safety factor (the percentage of deviation of the actual revenue threshold). To determine the impact of changes in revenue to changes in profit calculates production arm. The higher the leverage effect of the production, the more risky in terms of reduced profits is the situation of the enterprise.

For the separation of the total cost of constants and variables use the method of the highest and lowest points, which involves the following algorithm:

1. including data on volumes of production of various kinds of shoes, and the costs of its release selected maximum and minimum values;

2. It is the difference between the maximum and minimum values of volume production and cost;

3. It determines the rate of variable costs per product, by attributing the difference in the level of expenses for the period to the difference in the volume of production levels for the same period;

4. determined by the total amount of variable costs of the maximum and minimum volume production rate by multiplying the variable costs of the corresponding production volume;

5. determined by the total amount of fixed costs as a difference between all costs and variable costs value (Example 1) [10]

The minimum volume of production is to produce the Model A - 500 pairs, maximum - on the issue of model B - 1600 pairs.

The minimum and maximum cost of production of footwear models A and B are respectively 179465 rubles. $(358,93 \cdot 500)$ and 428,180 rubles. $(428,18$ $1000)$. The difference in the levels of production volume is 1100 pairs (1600-500) and in cost levels 248715 rubles. (428180-179465). Rate variables for one product costs amount to 226.1 (248715/1100). The total amount of variable costs to a minimum production volume is 113045 rubles. $(226,1.500)$, and the maximum amount -361760 rubles. $(226,1 \cdot 1600)$. The total amount of fixed costs $=66420179465$ $113045,428180-361760=66420$. Thus, for our 


\begin{tabular}{|c|c|c|c|c|c|c|}
\hline \multirow{4}{*}{ Impact Factor: } & ISRA (India) & $=3.117$ & SIS (USA) & $=0.912$ & ICV (Poland) & $=6.630$ \\
\hline & ISI (Dubai, UAE & $=0.829$ & РИНЦ (Russia & $=0.156$ & PIF (India) & $=1.940$ \\
\hline & GIF (Australia) & $=0.564$ & ESJI (KZ) & $=8.716$ & IBI (India) & $=4.260$ \\
\hline & JIF & $=1.500$ & SJIF (Morocce & $=5.667$ & OAJI (USA) & $=0.350$ \\
\hline
\end{tabular}

example, the value of fixed costs amount to 66420 rubles. and they are distributed between the speciesproduced footwear in proportion to the total cost of each product.

Profit from the sale of the Model A is a negative value. However, before taking a decision to exclude this type of shoes from the range, it is necessary to calculate the profit from the sale of all manufactured products. It is important that revenues exceed the sum total of variable costs. Table 1.

Table 1. The solution of Example 1

\begin{tabular}{|l|l|}
\hline Indicator & Meaning, rub. \\
\hline 1) Revenues from sales & 951008 \\
\hline 2) Variable costs & 798132 \\
\hline 3) Fixed costs & 66420 \\
\hline 4) Coating Amount 1-2 & 152876 \\
\hline 5) Ratio 4/1 & 0.16 \\
\hline 6) The threshold revenue, 3/5 & 415125 \\
\hline 7) The safety margin,,$(1-6) / 1 * 100$ & 56.35 \\
\hline 8) Gain & 86456 \\
\hline 9) The effect of the production arm, 4/8 & 1.77 \\
\hline
\end{tabular}

Let's see how to change the profit of the company in case of failure of the production unprofitable Model A. In this case, the firm's revenue will be reduced by the amount of proceeds from the sale of this product and its size will be 753,508 rubles. (951008-197500).

It will also reduce the total cost of the enterprise in the amount of variable costs required for the production and sale of brand shoes A. This value will be equal to 164290 rubles. Because fixed costs do not depend on the amount of revenue, the abandonment of the production of brand name shoes And not affect their overall value. Thus, the total cost of the enterprise without the production of brand name shoes And make 633842 rubles. (798132-164290). And the organization is not making a loss in its operations (753508-633842 = 119666 rubles.). Using the method of calculating the average value of the coating makes it possible to take a decision on whether to continue the production of footwear brand A. The average value of coverage for both brands of shoes is positive. If the company will reduce the release of Shine A grade by one unit, it will lose 66.6 rubles. of coverage of fixed costs. Exclusion from the production of the entire volume of the release of this brand will lead to a loss in the amount of 33300 rubles. $(500 \cdot 66,6)$. From the above it can be concluded that the shoe brand A should be kept in stock.

Thus, to make a decision based only on the value of the full costs and profits per unit of output, it is not always appropriate for the company to lose profits in the final result. Now consider the situation (Example 2 ), when the company plans to release a new product - a model in 1700 in the amount of steam for the price 467.40 p. for 1 pair. However, the production capacity of the organization are suitable for the production of only 4000 pairs of shoes. And if it is going to set up production of footwear models in, he would have to refuse the release of 500 pairs of other models. The question arises whether or not to enter into a range of new products, and if so, the production of some products should be reduced?

The average value of variables for a new kind of production cost is 375.34 rubles. Then the average value of the coating is equal to 92.06 rubles. (467.40 375.34). The increase in profits of the enterprise through the production of shoe models in the amount 156502 rubles. (1700 92,06). Among all kinds of shoes now made the smallest average value of the coating has a pattern B (66.6 rubles.). If we abandon the production of 500 pairs of shoes, the organization will lose $33300 \mathrm{rbl}$, At the same time the brand of shoe production in the company will receive an additional 156,502 rbl. companies benefit from the changes will be in the range of 123202 rubles. $(156,502-33,300)$. Let us see how to change a margin of safety, the effect of the production of the lever and the profit of the company in case of inclusion in the model shoe release in the range (Table 2).

Table 2. The solution of Example 2

\begin{tabular}{|l|l|}
\hline Indicator & Meaning, rub. \\
\hline 1) Revenues from sales & 1745588 \\
\hline
\end{tabular}




\begin{tabular}{|c|c|c|c|c|c|c|}
\hline \multirow{4}{*}{ Impact Factor: } & ISRA (India) & $=3.117$ & SIS (USA) & $=0.912$ & ICV (Poland) & $=6.630$ \\
\hline & ISI (Dubai, UAE & $=0.829$ & РИНЦ (Russia & $=0.156$ & PIF (India) & $=1.940$ \\
\hline & GIF (Australia) & $=0.564$ & ESJI (KZ) & $=8.716$ & IBI (India) & $=4.260$ \\
\hline & JIF & $=1.500$ & SJIF (Morocce & $=5.667$ & OAJI (USA) & $=0.350$ \\
\hline
\end{tabular}

\begin{tabular}{|l|l|}
\hline 2) Variable costs & 1520478 \\
\hline 3) Fixed costs & 66420 \\
\hline 4) Coating Amount 1-2 & 225110 \\
\hline 5) Ratio 4/1 & 0.13 \\
\hline 6) The threshold revenue, 3/5 & 515046 \\
\hline 7) The safety margin,\%, (1-6)/1*100 & 70.49 \\
\hline 8) Gain & 158690 \\
\hline 9) The effect of the production arm, 4/8 & 1.42 \\
\hline
\end{tabular}

These data show that the update range of companies the situation has improved:

- Profit increased from 86456 rubles. up to 158690 rub .;

- margin increased by $14.14 \%$ (70.49 - 56.35);

- the effect of the production arm declined by 0.35 points (from 1.77 to 1.42 ).

Thus, in the costing system of variable costs, income is recorded as a function of sales, and in the complete distribution system, it depends on the production and on the implementation.

Both considered systems have their advantages and disadvantages. For example, when production exceeds the volume of sales, higher profits will be shown in a full cost allocation system. In the case where the volume of sales, higher than the volume of production, higher profits will be reflected in the cost calculation of variable costs. However, when calculating the cost of variable costs, information for decision making can be obtained at a much smaller number of calculations. Choice for the enterprise management to timely and effective action to ensure its stable position of the company in an uncertain demand. This is especially important in the production of the entire product range of children's shoes, and when dealing with customers - with mothers and children, creating conditions for them to meet their interests.
In a market economy to survive in an everchanging economic environment, footwear enterprises should focus on the target audience:

- increase the amount of profit as a result of the volume of product sales company, reduced its production costs and improve product quality.

To get the desired profit in the conditions when the prices of footwear and production volumes are dictated by the market, the company always has to choose what products and how much to produce in terms of the cost of its production and taking into account the solvency of potential buyers.

A high quality, competitive footwear is a prerequisite for high-efficiency operation of the shoe business.

An important criterion for the shoe market competitiveness is its cost with a corresponding its quality and purchasing power of the population.

The main criterion of the viability and profitability of the enterprise is profit, to increase the loss is first necessary to reduce the cost of shoes.

The ratio of the changes in the calculation of each article costs depend on changes in the total cost, which includes all costs of production and sale of shoes.

An important factor affecting the level of production costs of footwear is to change the range and the process. (Tables 3-6) [11]

Table 3. The financial performance of your company in the children's shoes

\begin{tabular}{|c|c|c|c|c|c|c|c|}
\hline \multirow[t]{2}{*}{ Month } & \multirow{2}{*}{$\begin{array}{l}\text { Releas } \\
\mathrm{e} \\
\text { steam }\end{array}$} & \multicolumn{3}{|l|}{ Costs RUB. } & \multirow{2}{*}{$\begin{array}{l}\text { The cost } \\
\text { price, rbl. }\end{array}$} & \multirow{2}{*}{$\begin{array}{l}\text { Commodity } \\
\text { production } \\
\text { (in wholesale } \\
\text { prices), rub. }\end{array}$} & \multirow{2}{*}{$\begin{array}{l}\text { Profit } \\
\text { rubles. }\end{array}$} \\
\hline & & $\begin{array}{l}\text { Main and } \\
\text { auxiliary } \\
\text { materials }\end{array}$ & $\begin{array}{l}\text { The main and } \\
\text { additional RFP } \\
\text { with SVVF }\end{array}$ & Overhead & & & \\
\hline \multicolumn{8}{|c|}{ I quarter - spring $(56)-(15+19+22)$} \\
\hline $\begin{array}{l}\text { January } \\
3,909,699.7 \\
5\end{array}$ & 7095 & 1756438.2 & $414,631.8$ & $1,738,629.75$ & $\begin{array}{l}3,909,699 . \\
75\end{array}$ & 4321564.5 & $\begin{array}{l}411,864 . \\
75\end{array}$ \\
\hline $\begin{array}{l}\text { February } \\
4,976,286.3 \\
5\end{array}$ & 8987 & $\begin{array}{l}2,248,821.7 \\
2\end{array}$ & $525,200.28$ & $2,202,264.35$ & $\begin{array}{l}4,976,286 . \\
35\end{array}$ & 5473981.7 & $\begin{array}{l}497,695 . \\
35\end{array}$ \\
\hline $\begin{array}{l}\text { March } \\
5734226.3\end{array}$ & 10406 & $\begin{array}{l}2,576,109.3 \\
6\end{array}$ & $608,126.64$ & 2549990.3 & 5734226.3 & 6338294.6 & $\begin{array}{l}604,068 . \\
3\end{array}$ \\
\hline $\begin{array}{l}\text { I quarter } \\
14620212.4\end{array}$ & 26488 & $\begin{array}{l}6,581,369.2 \\
8\end{array}$ & $1,547,958.72$ & 6490884.4 & $\begin{array}{l}14620212 . \\
4\end{array}$ & 16133840.8 & $\begin{array}{l}1513628 \\
.4\end{array}$ \\
\hline
\end{tabular}




\begin{tabular}{|c|c|c|c|c|c|c|}
\hline \multirow{4}{*}{ Impact Factor: } & ISRA (India) & $=3.117$ & SIS (USA) & $=0.912$ & ICV (Poland) & $=6.630$ \\
\hline & ISI (Dubai, UAE & $=0.829$ & РИНЦ (Russia) & $=0.156$ & PIF (India) & $=1.940$ \\
\hline & GIF (Australia) & $=0.564$ & ESJI (KZ) & $=8.716$ & IBI (India) & $=4.260$ \\
\hline & JIF & $=1.500$ & SJIF (Morocco) & $=5.667$ & OAJI (USA) & $=0.350$ \\
\hline
\end{tabular}

\begin{tabular}{|l|l|l|l|l|l|l|l|}
\hline $\begin{array}{l}\text { April } \\
5,587,132.3 \\
2\end{array}$ & 11088 & $\begin{array}{l}2,305,971.3 \\
6\end{array}$ & $614,496.96$ & 2666664.0 & $\begin{array}{l}5,587,132 . \\
32\end{array}$ & 6098400.0 & $\begin{array}{l}511,267 . \\
68\end{array}$ \\
\hline $\begin{array}{l}\text { May } \\
5321078.4\end{array}$ & 10560 & 2196163.2 & $585,235.2$ & 2539680.0 & 5321078.4 & 5808000.0 & $\begin{array}{l}486,921 . \\
6\end{array}$ \\
\hline $\begin{array}{l}\text { June } \\
5,587,132.3 \\
2\end{array}$ & 11088 & $\begin{array}{l}2,305,971.3 \\
6\end{array}$ & $614,496.96$ & 2666664.0 & $\begin{array}{l}5,587,132 . \\
32\end{array}$ & 6098400.0 & $\begin{array}{l}511,267 . \\
68\end{array}$ \\
\hline $\begin{array}{l}\text { II quarter of } \\
16,495,343 . \\
04\end{array}$ & 32736 & $6,808,105.9$ & $1,814,229.12$ & 7873008 & $16,495,343$ & 18004800.0 & 1509457 \\
\hline & 2 & & & & \\
\hline
\end{tabular}

Table 4. Financial results of the company for the implementation of women's shoes

\begin{tabular}{|c|c|c|c|c|c|c|c|}
\hline \multirow[t]{2}{*}{ Month } & \multirow{2}{*}{$\begin{array}{l}\text { Releas } \\
\mathrm{e} \\
\text { steam }\end{array}$} & \multicolumn{3}{|l|}{ Costs RUB. } & \multirow{2}{*}{$\begin{array}{l}\text { The cost } \\
\text { price, rbl. }\end{array}$} & \multirow[b]{2}{*}{$\begin{array}{l}\text { Commodity } \\
\text { production } \\
\text { (in } \\
\text { wholesale } \\
\text { prices), rub. }\end{array}$} & \multirow{2}{*}{$\begin{array}{l}\text { Profit } \\
\text { rubles. }\end{array}$} \\
\hline & & $\begin{array}{l}\text { Main and } \\
\text { auxiliary } \\
\text { materials }\end{array}$ & $\begin{array}{l}\text { The main } \\
\text { and } \\
\text { additional } \\
\text { RFP with } \\
\text { SVVF }\end{array}$ & Overhead & & & \\
\hline \multicolumn{8}{|c|}{ I quarter - spring $(56)-(15+19+22)$} \\
\hline $\begin{array}{l}\text { January } \\
2856754.8\end{array}$ & 3060 & 1671861.6 & $455,695.2$ & 729198 & 2856754.8 & 3241519.2 & $384,764.4$ \\
\hline $\begin{array}{l}\text { February } \\
3,618,556.0 \\
8\end{array}$ & 3876 & $2,117,691.36$ & $577,213.92$ & $923,650.8$ & $3,618,556.08$ & $\begin{array}{l}4,105,924.3 \\
2\end{array}$ & $487,368.24$ \\
\hline $\begin{array}{l}\text { March } \\
4,205,419.0 \\
4\end{array}$ & 4488 & $2,447,575.68$ & $688,352.96$ & 1069490.4 & $4,205,419.04$ & $\begin{array}{l}4,754,228.1 \\
6\end{array}$ & $548,809.12$ \\
\hline $\begin{array}{l}\text { I quarter of } \\
10,680,729 \text {. } \\
92\end{array}$ & 11424 & $6,237,128.64$ & $\begin{array}{l}1,721,262 . \\
08\end{array}$ & 2722339.2 & $\begin{array}{l}10,680,729.9 \\
2\end{array}$ & $\begin{array}{l}12,101,671 . \\
68\end{array}$ & $\begin{array}{l}1,420,941 . \\
76\end{array}$ \\
\hline
\end{tabular}




\begin{tabular}{|c|c|c|c|c|c|c|}
\hline \multirow{4}{*}{ Impact Factor: } & ISRA (India) & $=3.117$ & SIS (USA) & $=0.912$ & ICV (Poland) & $=6.630$ \\
\hline & ISI (Dubai, UAE & $=0.829$ & РИНЦ (Russia) & $=0.156$ & PIF (India) & $=1.940$ \\
\hline & GIF (Australia) & $=0.564$ & ESJI (KZ) & $=8.716$ & IBI (India) & $=4.260$ \\
\hline & JIF & $=1.500$ & SJIF (Morocco) & $=5.667$ & OAJI (USA) & $=0.350$ \\
\hline
\end{tabular}

\begin{tabular}{|c|c|c|c|c|c|c|c|}
\hline $\begin{array}{l}\text { April } \\
4,503,549.5 \\
4\end{array}$ & 5334 & 2819819.1 & $451,363.08$ & $1,232,367.36$ & $4,503,549.54$ & $\begin{array}{l}5,198,409.7 \\
2\end{array}$ & $694,860.18$ \\
\hline $\begin{array}{l}\text { May } \\
4289094.8\end{array}$ & 5080 & 2685542.0 & $429,869.6$ & 1173683.2 & 4289094.8 & 4950866.4 & $661,771.6$ \\
\hline $\begin{array}{l}\text { June } \\
4,503,549.5 \\
4\end{array}$ & 5334 & 2819819.1 & $451,363.08$ & $1,232,367.36$ & $4,503,549.54$ & $\begin{array}{l}5,198,409.7 \\
2\end{array}$ & $694,860.18$ \\
\hline $\begin{array}{l}\text { II quarter of } \\
13,296,193 \text {. } \\
88\end{array}$ & 15748 & 8325180.1 & $\begin{array}{l}1,332,595 \\
76\end{array}$ & $3,638,417.92$ & $\begin{array}{l}13,296,193.8 \\
8\end{array}$ & $\begin{array}{l}15,347,685 \\
84\end{array}$ & $\begin{array}{l}2,051,491 . \\
96\end{array}$ \\
\hline \multicolumn{8}{|c|}{ III quarter - autumn (66) - $(24+23+22)$} \\
\hline $\begin{array}{l}\text { July } \\
4,038,068.3 \\
7\end{array}$ & 3801 & $2,461,033.47$ & $528,681.09$ & $1,048,353.81$ & $4,038,068.37$ & $\begin{array}{l}4,831,793.1 \\
9\end{array}$ & $793,724.82$ \\
\hline $\begin{array}{l}\text { August } \\
4,422,646.3 \\
1\end{array}$ & 4163 & $2,695,417.61$ & $579,031.67$ & $1,148,197.03$ & $4,422,646.31$ & $\begin{array}{l}5,304,452.9 \\
7\end{array}$ & $881,806.66$ \\
\hline $\begin{array}{l}\text { September } \\
4,230,357.3 \\
4\end{array}$ & 3982 & $2,578,225.54$ & $553,856.38$ & $1,098,275.42$ & $4,230,357.34$ & $\begin{array}{l}5,061,878.5 \\
8\end{array}$ & $831,521.24$ \\
\hline $\begin{array}{l}\text { III quarter } \\
12691072.0 \\
2\end{array}$ & 11946 & $7,734,676.62$ & $\begin{array}{l}1,661,569 . \\
14\end{array}$ & $3,294,826.26$ & $\begin{array}{l}12,691,072.0 \\
2\end{array}$ & $\begin{array}{l}15,185,635 \\
74\end{array}$ & $\begin{array}{l}2,494,563 . \\
72\end{array}$ \\
\hline \multicolumn{8}{|c|}{ IV quarter - Winter (64) - $(21+21+22)$} \\
\hline $\begin{array}{l}\text { October } \\
7,169,000.5 \\
8\end{array}$ & 3402 & $5,261,975.46$ & $750,413.16$ & $1,156,611.96$ & $7,169,000.58$ & $\begin{array}{l}8,649,142.7 \\
4\end{array}$ & $\begin{array}{l}1,480,142 . \\
16\end{array}$ \\
\hline $\begin{array}{l}\text { November } \\
7,169,000.5 \\
8\end{array}$ & 3402 & $5,261,975.46$ & $750,413.16$ & $1,156,611.96$ & $7,169,000.58$ & $\begin{array}{l}8,649,142.7 \\
4\end{array}$ & $\begin{array}{l}1,480,142 . \\
16\end{array}$ \\
\hline $\begin{array}{l}\text { December } \\
7,510,381.5 \\
6\end{array}$ & 3564 & $5,512,545.72$ & $786,147.12$ & $1,211,688.72$ & $7,510,381.56$ & $\begin{array}{l}9,061,006.6 \\
8\end{array}$ & $\begin{array}{l}1,550,625 . \\
12\end{array}$ \\
\hline $\begin{array}{l}\text { IV quarter } \\
21848382.7 \\
2\end{array}$ & 10368 & $\begin{array}{l}16,036,496.6 \\
4\end{array}$ & $\begin{array}{l}2,286,973 \\
44\end{array}$ & $3,524,912.64$ & $\begin{array}{l}21,848,382.7 \\
2\end{array}$ & $\begin{array}{l}26,359,292 . \\
16\end{array}$ & $\begin{array}{l}4,510,909 . \\
44\end{array}$ \\
\hline $\begin{array}{l}\text { For the year } \\
58,516,378 . \\
54\end{array}$ & 49489 & 38333482.0 & $\begin{array}{l}7,002,400 . \\
42\end{array}$ & $\begin{array}{l}13,180,496.0 \\
2\end{array}$ & $\begin{array}{l}58,516,378.5 \\
4\end{array}$ & $\begin{array}{l}68,994,285 . \\
42\end{array}$ & $\begin{array}{l}10,477,906 \\
.88\end{array}$ \\
\hline
\end{tabular}

Table 5. Financial results of the company for the implementation of men's shoes

\begin{tabular}{|c|c|c|c|c|c|c|c|}
\hline \multirow[t]{2}{*}{ Month } & \multirow{2}{*}{$\begin{array}{l}\text { Rel } \\
\text { ease } \\
\text { stea } \\
\text { m }\end{array}$} & \multicolumn{3}{|l|}{ Costs RUB. } & \multirow{2}{*}{$\begin{array}{l}\text { The cost } \\
\text { price, rbl. }\end{array}$} & \multirow{2}{*}{$\begin{array}{l}\text { Commodity } \\
\text { production } \\
\text { (in wholesale } \\
\text { prices), rub. }\end{array}$} & \multirow[t]{2}{*}{ Profit rubles. } \\
\hline & & $\begin{array}{l}\text { Main and } \\
\text { auxiliary } \\
\text { materials }\end{array}$ & $\begin{array}{l}\text { The main } \\
\text { and } \\
\text { additional } \\
\text { RFP with } \\
\text { SVVF }\end{array}$ & Overhead & & & \\
\hline \multicolumn{8}{|c|}{ I quarter - spring (56) $-(15+19+22)$} \\
\hline $\begin{array}{l}\text { January } \\
3,662,091.75\end{array}$ & $\begin{array}{l}427 \\
5\end{array}$ & $\begin{array}{l}2,417,213 \\
25\end{array}$ & $602,860.5$ & $642,618.0$ & $\begin{array}{l}3,662,691.7 \\
5\end{array}$ & 4419495 & $756,803.23$ \\
\hline $\begin{array}{l}\text { February } \\
4,639,409.55\end{array}$ & $\begin{array}{l}541 \\
5\end{array}$ & $\begin{array}{l}3,061,803 . \\
45\end{array}$ & $763,623.3$ & $813,982.8$ & $\begin{array}{l}4,639,409.5 \\
5\end{array}$ & 5598027 & $958,617.45$ \\
\hline $\begin{array}{l}\text { March } \\
5371947.9\end{array}$ & $\begin{array}{l}627 \\
0\end{array}$ & 3545246.1 & $884,195.4$ & $942,506.4$ & 5371947.9 & 6481926 & 1109978.1 \\
\hline
\end{tabular}




\begin{tabular}{|c|c|c|c|c|c|c|}
\hline \multirow{4}{*}{ Impact Factor: } & ISRA (India) & $=3.117$ & SIS (USA) & $=0.912$ & ICV (Poland) & $=6.630$ \\
\hline & ISI (Dubai, UAE & $=0.829$ & РИНЦ (Russia) & $=0.156$ & PIF (India) & $=1.940$ \\
\hline & GIF (Australia) & $=0.564$ & ESJI (KZ) & $=8.716$ & IBI (India) & $=4.260$ \\
\hline & JIF & $=1.500$ & SJIF (Morocco) & $=5.667$ & OAJI (USA) & $=0.350$ \\
\hline
\end{tabular}

\begin{tabular}{|c|c|c|c|c|c|c|c|}
\hline $\begin{array}{l}\text { I quarter } \\
13674049.2\end{array}$ & \begin{tabular}{l|l}
$r$ & 159 \\
60
\end{tabular} & 9024262.8 & 2250679.2 & 2399107.2 & 13674049.2 & 16499448 & 2825398.8 \\
\hline \multicolumn{8}{|c|}{ II quarter - summer $(62)-(21+20+21)$} \\
\hline $\begin{array}{l}\text { April } \\
3794943.0\end{array}$ & $\begin{array}{l}590 \\
1\end{array}$ & $\begin{array}{l}2,338,035 . \\
21\end{array}$ & $638,960.28$ & $817,347.51$ & 3794343.0 & $4,450,711.23$ & $656,368.23$ \\
\hline $\begin{array}{l}\text { May } \\
3613660.0\end{array}$ & $\begin{array}{l}562 \\
0\end{array}$ & 2226700.2 & $608,533.6$ & $778,426.2$ & 3613660.0 & 4238772.6 & $625,112.6$ \\
\hline $\begin{array}{l}\text { June } \\
3794343.0\end{array}$ & $\begin{array}{l}590 \\
1\end{array}$ & $\begin{array}{l}2,338,035 \\
21\end{array}$ & $638,960.28$ & $817,347.51$ & 3794343.0 & $4,450,711.23$ & $656,368.23$ \\
\hline $\begin{array}{l}\text { II quarter of } \\
11202346\end{array}$ & \begin{tabular}{l|l}
$f$ & 174 \\
22
\end{tabular} & $\begin{array}{l}6,902,770 . \\
62\end{array}$ & $\begin{array}{l}1,886,454 . \\
16\end{array}$ & $2,413,121.22$ & 11202346 & $\begin{array}{l}13,140,195.0 \\
6\end{array}$ & $1,937,849.06$ \\
\hline \multicolumn{8}{|c|}{ III quarter - autumn (66) - $(24+23+22)$} \\
\hline $\begin{array}{l}\text { July } \\
4,792,159.4 \\
9 \\
\end{array}$ & 5292 & $\begin{array}{l}3,219,403 . \\
02\end{array}$ & $429,542.11$ & $1,143,214.35$ & $\begin{array}{l}4,792,159 . \\
49\end{array}$ & 6099030 & $\begin{array}{l}1,306,870.5 \\
1\end{array}$ \\
\hline $\begin{array}{l}\text { August } \\
5,249,555.6 \\
3\end{array}$ & 5796 & $\begin{array}{l}3,526,012 . \\
83\end{array}$ & $470,450.89$ & $1,252,091.91$ & $\begin{array}{l}5,249,555 \\
63\end{array}$ & 6679890 & $\begin{array}{l}1,430,334.3 \\
7\end{array}$ \\
\hline $\begin{array}{l}\text { September } \\
5,020,357.5 \\
6\end{array}$ & 5,544 & $\begin{array}{l}3,372,707 \\
92\end{array}$ & $449,996.5$ & $1,197,653.14$ & $\begin{array}{l}5,020,357 . \\
56\end{array}$ & 6389460 & $\begin{array}{l}1,369,102.4 \\
4\end{array}$ \\
\hline $\begin{array}{l}\text { III quarter } \\
15061072.6 \\
8\end{array}$ & 16632 & $\begin{array}{l}10,118,123 \\
.77\end{array}$ & 1349989.5 & 3592959.4 & $\begin{array}{l}15,061,072 \\
.68\end{array}$ & 19168380 & $\begin{array}{l}4,107,307.3 \\
2\end{array}$ \\
\hline \multicolumn{8}{|c|}{ IV quarter - Winter (64) - $(21+21+22)$} \\
\hline $\begin{array}{l}\text { October } \\
4419723.0\end{array}$ & 4389 & $\begin{array}{l}3,032,008 . \\
98\end{array}$ & $661,466.19$ & $726,247.83$ & 4419723.0 & 5207109.6 & $787,386.6$ \\
\hline $\begin{array}{l}\text { November } \\
4419723.0 \\
\end{array}$ & 4389 & $\begin{array}{l}3,032,008 . \\
98\end{array}$ & $661,466.19$ & $726,247.83$ & 4419723.0 & 5207109.6 & $787,386.6$ \\
\hline $\begin{array}{l}\text { December } \\
4630186.0\end{array}$ & 4598 & $\begin{array}{l}3,176,390 . \\
36\end{array}$ & $692,964.58$ & $760,831.06$ & 4630186.0 & 5455067.2 & $824,881.2$ \\
\hline $\begin{array}{l}\text { IV quarter } \\
13469632.0\end{array}$ & 13376 & $\begin{array}{l}9,240,408 . \\
32\end{array}$ & $\begin{array}{l}2,015,896 . \\
96\end{array}$ & $2,213,326.72$ & $\begin{array}{l}13469632 . \\
0\end{array}$ & 15869286.4 & 2399654.4 \\
\hline $\begin{array}{l}\text { For the year } \\
53,407,099 \text {. } \\
87\end{array}$ & 63390 & $\begin{array}{l}35,285,565 \\
.51\end{array}$ & $\begin{array}{l}7,503,019 . \\
82\end{array}$ & $\begin{array}{l}10,618,514.5 \\
4\end{array}$ & $\begin{array}{l}53,407,099 \\
.87\end{array}$ & $64,677,309.46$ & $\begin{array}{l}11,270,209 . \\
59\end{array}$ \\
\hline
\end{tabular}

Table 6. The impact of the implementation of the shoe on the financial condition of the enterprise

\begin{tabular}{|c|c|c|c|c|c|}
\hline \multicolumn{6}{|l|}{ Men's shoes } \\
\hline $\begin{array}{l}\text { volume } \\
\text { realization } \%\end{array}$ & $100 \%$ & $80 \%$ & $60 \%$ & $48 \%$ & $40 \%$ \\
\hline $\begin{array}{l}\text { Profit / loss for the } \\
\text { month, rub. }\end{array}$ & $824,881.2$ & $207,739.04$ & $190,596.51$ & 0 & $-126,545.78$ \\
\hline $\begin{array}{l}\text { tax on } \\
\text { profit } 20 \%\end{array}$ & $164,976.22$ & 41547.8 & 38119.3 & - & - \\
\hline $\begin{array}{l}\text { Tax } \\
\text { property, } 2.2 \%\end{array}$ & 3483.3 & 3483.3 & 3483.3 & 3483.3 & 3483.3 \\
\hline $\begin{array}{l}\text { Net profit / loss for the } \\
\text { month, rub. }\end{array}$ & $656,421.7$ & 162708 & 148994 & -3483.3 & -3483.3 \\
\hline $\begin{array}{l}\text { Profit / loss for the year, } \\
\text { rbl. }\end{array}$ & 9898574.4 & $2,492,868.48$ & $2,287,158.12$ & 0 & $-1,518,549.36$ \\
\hline $\begin{array}{l}\text { pure } \\
\text { Profit / loss for the year, } \\
\text { RUR. }\end{array}$ & 7877060.4 & 1952496 & 1787928 & -41799.6 & -41799.6 \\
\hline \multicolumn{6}{|l|}{ Women's shoes } \\
\hline $\begin{array}{l}\text { volume } \\
\text { realization\% }\end{array}$ & $100 \%$ & $80 \%$ & $60 \%$ & $44 \%$ & $40 \%$ \\
\hline
\end{tabular}




\begin{tabular}{|c|c|c|c|c|c|c|}
\hline \multirow{4}{*}{ Impact Factor: } & ISRA (India) & $=3.117$ & SIS (USA) & $=0.912$ & ICV (Poland) & $=6.630$ \\
\hline & ISI (Dubai, UAE & $=0.829$ & РИНЦ (Russia & $=0.156$ & PIF (India) & $=1.940$ \\
\hline & GIF (Australia) & $=0.564$ & ESJI (KZ) & $=8.716$ & IBI (India) & $=4.260$ \\
\hline & JIF & $=1.500$ & SJIF (Morocce & $=5.667$ & OAJI (USA) & $=0.350$ \\
\hline
\end{tabular}

\begin{tabular}{|c|c|c|c|c|c|}
\hline $\begin{array}{l}\text { Gains / Losses } \\
\text { for the month, rub. }\end{array}$ & $1,550,625.12$ & $998,162.35$ & $445,699.56$ & 0 & $-106,763.19$ \\
\hline $\begin{array}{l}\text { tax on } \\
\text { profit } 20 \%\end{array}$ & $310,125.02$ & $199,632.47$ & 89139.912 & - & - \\
\hline $\begin{array}{l}\text { Tax } \\
\text { property, } 2.2 \%\end{array}$ & 3483.3 & 3483.3 & 3483.3 & 3483.3 & 3483.3 \\
\hline $\begin{array}{l}\text { Net profit / loss for the } \\
\text { month, rub. }\end{array}$ & 1237017 & $795,046.6$ & $353,076.3$ & -3483.3 & - 3483.3 \\
\hline $\begin{array}{l}\text { Profit / loss for the year, } \\
\text { rbl. }\end{array}$ & 18607501 & 11977948 & 5348395 & 0 & $-1,281,158.28$ \\
\hline $\begin{array}{l}\text { pure } \\
\text { Profit / loss for the year, } \\
\text { RUR. }\end{array}$ & 14844204 & 9540559 & 4236916 & - 41799.6 & - 41799.6 \\
\hline \multicolumn{6}{|l|}{ Children's shoes } \\
\hline $\begin{array}{l}\text { volume } \\
\text { realization\% }\end{array}$ & $100 \%$ & $90 \%$ & $83 \%$ & $80 \%$ & - \\
\hline $\begin{array}{l}\text { Profit / loss for the } \\
\text { month, rub. }\end{array}$ & $511,267.68$ & $495,905.15$ & 0 & $-416,365.49$ & - \\
\hline $\begin{array}{l}\text { tax on } \\
\text { profit } 20 \%\end{array}$ & $102,253.54$ & 9918103 & - & - & - \\
\hline $\begin{array}{l}\text { Tax } \\
\text { property, } 2.2 \%\end{array}$ & 3483.3 & 3483.3 & 3483.3 & 3483.3 & - \\
\hline $\begin{array}{l}\text { Net profit / loss for the } \\
\text { month, rub .. }\end{array}$ & $405,530.84$ & 39668929 & -3483.3 & -3483.3 & - \\
\hline $\begin{array}{l}\text { Profit / loss for the year, } \\
\text { rbl. }\end{array}$ & 6135212 & 49590515 & 0 & - 4,996,385.88 & - \\
\hline $\begin{array}{l}\text { pure } \\
\text { Profit / loss for the year, } \\
\text { RUR. }\end{array}$ & 4866370 & 39668929 & - 41799.6 & -41799.6 & - \\
\hline
\end{tabular}

3-6 tables of data suggest that the $100 \%$ implementation of the shoe to provide compensation for costs not only for production and sales of shoes, but remains net income, which demonstrates the effectiveness of the company during the analyzed month, as well as the right assortment of marketing policy of the company. This result of the work will allow the company to distribute the net profit on the formation of a financial reserve, payment of dividends, the development of production, financing of social programs, and others.

When the sale of this type of footwear is not in full, then such an outcome adversely affects the performance of the company. In this case, the presence of residues unrealizable shoe reduces the total amount of revenue, increases costs and leads to additional costs for the storage of goods.

When calculating the dimensionless evaluation indicators of competitiveness of enterprises through the software there is a need to formulate these same criteria as their probative bazy. So, for example, unit profit is calculated depending on the profitability of production, that is, first formulated margins from 5\% to $25 \%$ and then laid the amount of profit per unit of output. A similar feature exists with the definition of productivity criterion, because at first use innovative processes, formed on the basis of universal and multifunctional equipment maintenance which should be highly trusted and responsible executives, empathic for the overall result of the entire production cycle, guaranteeing them the production of marketable and competitive products, enjoyed by consumers of domestic markets in high demand. Calculation of fixed costs per unit of production and semi-variable costs per unit of output is interconnected with the peculiarities of the organization of competitive and marketable products, including for children. Performance analysis of the leading foreign manufacturers confirms the fact that, if fixed costs are $20 \%-40 \%$ of the cost of production, then, of course, conditional instance variables costs - $60 \%-80 \%$.If this again need to focus on the production of feature products for children, and when profit margins, fixed costs and semi-variable costs are generated based on the implementation of the requirements of technical regulations and normative documents and acts to ensure their safety when using them life. And if this is due to the need of their production takmi stringent performance - the state and the producers have to be interested in each other, and to provide producers compensation for the additional costs of compliance and assurance that made Highlighted not bring harm to children's health.

Of course, if the criteria for loss of wages per unit of output has to go to zero, and the volume of manufacture of shoes with $1 \mathrm{~m} 2$ - to its maximum 


\begin{tabular}{|c|c|c|c|c|c|c|}
\hline \multirow{4}{*}{ Impact Factor: } & ISRA (India) & $=3.117$ & SIS (USA) & $=0.912$ & ICV (Poland) & $=6.630$ \\
\hline & ISI (Dubai, UAE & $=0.829$ & РИНЦ (Russia & $=0.156$ & PIF (India) & $=1.940$ \\
\hline & GIF (Australia) & $=0.564$ & ESJI (KZ) & $=8.716$ & IBI (India) & $=4.260$ \\
\hline & JIF & $=1.500$ & SJIF (Morocce & $=5.667$ & OAJI (USA) & $=0.350$ \\
\hline
\end{tabular}

possible value, and the cost of 1 commodity products ruble shall endeavor to achieve the minimum possible value and the cost of equipment per unit of flow setting also aspire to the minimum possible value and other criteria - to their maximum possible values'together dimensionless performance evaluation developed innovative technological processes (K) should always page acquainted unit and thereby always confirm that designed an innovative process for the production of the company they importsubstituting products will be successful in their work for the benefit of the population of the regions where they operate,

Table 7 - Criteria for assessing the competitiveness of and demand for the eyes of children's shoes of the child

\begin{tabular}{|l|l|l|}
\hline number & $\begin{array}{l}\text { The list of factors to evaluate the competitive capacity of enterprises and regions of the } \\
\text { Southern Federal District North Caucasus Federal District in the production of } \\
\text { children's shoes }\end{array}$ & Rank \\
\hline one & Form forefoot & \\
\hline 2 & Quality children's shoes & \\
\hline 3 & The flexibility of children's shoes & \\
\hline four & Price of children's shoes & \\
\hline five & comfort & \\
\hline 6 & The level of service of parents and children in shops and malls & \\
\hline 7 & Colour & \\
\hline eight & The warranty period for children's shoes & \\
\hline 9 & The height of the heel portion elation -up to 40 mm & \\
\hline ten & Elation heel height of the shoe 40 mm -svyshe & \\
\hline eleven & Weight & \\
\hline 12 & Maintainability children's shoes its expediency & \\
\hline 13 & Materials for the bottom of shoes & \\
\hline 14 & Materials for uppers & \\
\hline 15 & Point of sale of footwear for children -Interior store or shopping center & \\
\hline sixteen & What types of children's shoes are preferred: Winter & \\
\hline 17 & autumn & \\
\hline 18 & spring & \\
\hline nineteen & summer & \\
\hline 20 & Durability fastening shoe bottom & \\
\hline 21 & Variety assortment of shoes for children in shops and malls & \\
\hline 22 & Compliance towards fashion & \\
\hline
\end{tabular}

Table 2 - Results of treatment of questioning children that participated in the survey for assessing the competitiveness of and demand for children's shoes

\begin{tabular}{|c|c|c|c|c|c|c|c|c|c|c|c|c|c|c|c|c|c|c|c|c|c|c|c|}
\hline $\begin{array}{l}\text { Фак } \\
\text { тор } \\
\text { Экс } \\
\text { nep } \\
\text { m }\end{array}$ & $X_{I}$ & $X_{2}$ & $X_{3}$ & $X_{4}$ & $X_{5}$ & $X_{6}$ & $\boldsymbol{X}_{7}$ & $X_{8}$ & $X_{9}$ & $\begin{array}{c}X \\
10\end{array}$ & $\begin{array}{l}X \\
11\end{array}$ & $\begin{array}{l}X \\
12\end{array}$ & $\begin{array}{l}X \\
13\end{array}$ & $\begin{array}{l}X \\
14\end{array}$ & $\begin{array}{l}X \\
15\end{array}$ & $\begin{array}{l}X \\
16\end{array}$ & $\begin{array}{l}X \\
17\end{array}$ & $\begin{array}{l}X \\
18\end{array}$ & $\begin{array}{l}X \\
19\end{array}$ & $\begin{array}{l}X \\
20\end{array}$ & $\begin{array}{l}X \\
21\end{array}$ & $\begin{array}{l}X \\
22\end{array}$ & $\kappa \kappa$ \\
\hline 1 & 5 & 8 & 6 & 2 & 7 & 9 & 10 & 4 & 11 & 16 & 18 & $\begin{array}{l}12 \\
, 5\end{array}$ & 15 & 14 & 3 & 19 & 20 & $\begin{array}{l}21 \\
, 5\end{array}$ & 17 & $\begin{array}{l}12 \\
, 5\end{array}$ & $\begin{array}{l}21 \\
, 5\end{array}$ & 1 & $\begin{array}{l}0,3 \\
3\end{array}$ \\
\hline 2 & 3 & 2 & 15 & 14 & 8 & 9 & 16 & 5 & 17 & $\begin{array}{c}10 \\
, 5\end{array}$ & 13 & 18 & 1 & 19 & 4 & 20 & 6 & $\begin{array}{c}10 \\
, 5\end{array}$ & 21 & 22 & 12 & 7 & $\begin{array}{l}0,4 \\
4\end{array}$ \\
\hline 3 & 8 & 16 & 22 & 5 & 2 & 10 & 6 & 7 & 11 & $\begin{array}{l}17 \\
, 5\end{array}$ & 12 & 14 & 1 & 21 & 3 & 13 & 15 & $\begin{array}{l}17 \\
, 5\end{array}$ & 20 & 19 & 4 & 9 & $\begin{array}{l}0,5 \\
7\end{array}$ \\
\hline 4 & 11 & 14 & 22 & 15 & 2 & 6 & 12 & 4 & 5 & $\begin{array}{l}7 \\
5\end{array}$ & 10 & 20 & 1 & 19 & 3 & 16 & 17 & $\begin{array}{l}7, \\
5\end{array}$ & 18 & 21 & 9 & 13 & $\begin{array}{l}0,3 \\
5\end{array}$ \\
\hline 5 & 16 & $\begin{array}{c}2, \\
5\end{array}$ & 17 & 15 & 18 & 4 & $\begin{array}{l}2, \\
5\end{array}$ & 6 & 7 & 14 & 8 & 11 & 1 & 9 & 19 & 22 & 10 & 21 & 20 & 12 & 5 & 13 & $\begin{array}{l}0,2 \\
8\end{array}$ \\
\hline 6 & 1 & 2 & 10 & 12 & 7 & 13 & 11 & 3 & 14 & 15 & 8 & 16 & 17 & 21 & 4 & 9 & 20 & 22 & 5 & 6 & 19 & 18 & $\begin{array}{l}0,3 \\
4\end{array}$ \\
\hline 7 & 12 & 11 & 14 & 16 & 10 & 9 & 2 & 20 & 8 & 19 & 7 & 18 & 1 & 13 & 22 & 15 & 17 & 6 & 21 & 5 & 3 & 4 & $\begin{array}{l}0,2 \\
9\end{array}$ \\
\hline 8 & 2 & 19 & 9 & 12 & 8 & 3 & 11 & 20 & 4 & 22 & 7 & 13 & 5 & 17 & 21 & 10 & 14 & 18 & 16 & 1 & 6 & 15 & $\begin{array}{l}0,2 \\
6\end{array}$ \\
\hline
\end{tabular}




\begin{tabular}{|c|c|c|c|c|c|c|}
\hline \multirow{4}{*}{ Impact Factor: } & ISRA (India) & $=3.117$ & SIS (USA) & $=0.912$ & ICV (Poland) & $=6.630$ \\
\hline & ISI (Dubai, UAE & $=0.829$ & РИНЦ (Russia) & $=0.156$ & PIF (India) & $=1.940$ \\
\hline & GIF (Australia) & $=0.564$ & ESJI (KZ) & $=8.716$ & IBI (India) & $=4.260$ \\
\hline & JIF & $=1.500$ & SJIF (Morocco) & $=5.667$ & OAJI (USA) & $=0.350$ \\
\hline
\end{tabular}

\begin{tabular}{|c|c|c|c|c|c|c|c|c|c|c|c|c|c|c|c|c|c|c|c|c|c|c|c|}
\hline 9 & 10 & 4 & 18 & 3 & 8 & 19 & 9 & 14 & 21 & 15 & 5 & 17 & 1 & 12 & 11 & 16 & 20 & 22 & 13 & 6 & & 7 & \begin{tabular}{|l}
0,4 \\
9 \\
\end{tabular} \\
\hline 10 & 6 & 7 & 17 & 18 & 16 & 14 & 5 & 19 & 13 & 8 & 4 & 9 & 10 & 11 & 22 & 3 & 21 & 12 & 20 & \begin{tabular}{|l|}
1 \\
5 \\
\end{tabular} & 1 & 2 & \begin{tabular}{l|}
0,3 \\
0 \\
\end{tabular} \\
\hline 11 & 10 & 5 & 4 & 9 & 3 & 12 & 11 & 8 & 1 & 22 & 2 & 13 & 14 & 16 & 17 & 6 & 20 & 18 & 21 & 7 & 19 & 15 & $\begin{array}{l}0,3 \\
3 \\
\end{array}$ \\
\hline 12 & 8 & 3 & 9 & 13 & 2 & 22 & 14 & 11 & 15 & 19 & 4 & 17 & 6 & 16 & 20 & 10 & 18 & 21 & 12 & 1 & 5 & 7 & \begin{tabular}{|l|l}
0,3 \\
7
\end{tabular} \\
\hline 13 & 4 & 1 & 9 & 6 & 13 & 15 & 3 & 19 & 14 & 8 & 18 & 20 & 17 & 21 & 5 & 16 & 10 & 2 & 22 & 12 & 7 & 11 & \begin{tabular}{|l|}
0,2 \\
7
\end{tabular} \\
\hline 14 & 13 & 14 & 10 & 3 & 1 & 2 & 16 & 15 & 20 & 5 & 21 & 17 & 4 & 11 & 19 & 7 & 18 & 6 & 22 & 9 & 12 & 8 & \begin{tabular}{|l}
0,2 \\
1 \\
\end{tabular} \\
\hline 15 & 7 & 14 & 3 & 11 & 17 & 19 & 4 & 12 & 9 & 21 & 1 & 18 & 5 & 20 & 22 & 15 & 8 & 16 & 2 & 13 & 6 & 10 & \begin{tabular}{|l|l}
0,2 \\
4 \\
\end{tabular} \\
\hline 16 & 2 & 3 & 5 & 6 & 8 & 4 & 10 & 15 & 7 & 11 & 18 & 16 & 1 & 12 & 21 & 19 & 13 & 14 & 17 & 22 & 20 & 9 & \begin{tabular}{|l|}
0,3 \\
9
\end{tabular} \\
\hline 17 & 6 & 15 & 7 & 8 & 11 & 10 & 9 & 1 & 21 & 20 & 16 & 17 & 2 & 12 & 3 & 22 & 19 & 13 & 4 & 18 & 14 & 5 & $\begin{array}{l}0,2 \\
4\end{array}$ \\
\hline 18 & 3 & 1 & 22 & 6 & 19 & 13 & 14 & 11 & 17 & 18 & 2 & 21 & 12 & 16 & 4 & 5 & 10 & 15 & 20 & 7 & 8 & 9 & \begin{tabular}{|l|}
0,3 \\
7
\end{tabular} \\
\hline 19 & 2 & 3 & 6 & 7 & 12 & 11 & 17 & 13 & 18 & 16 & 1 & 20 & 5 & 14 & 19 & 8 & 15 & 9 & 10 & 22 & 21 & 4 & \begin{tabular}{|l}
0,4 \\
3 \\
\end{tabular} \\
\hline 20 & 2 & 12 & 8 & 11 & 14 & 7 & 15 & 10 & 17 & 9 & 16 & 18 & 1 & 20 & 5 & 19 & 4 & 13 & 22 & 6 & 21 & 3 & \begin{tabular}{|l}
0,2 \\
3 \\
\end{tabular} \\
\hline 21 & 1 & 14 & 21 & 9 & 8 & 15 & 16 & 7 & 5 & 6 & 4 & 18 & 19 & 17 & 10 & 20 & 22 & 11 & 12 & 13 & 2 & 3 & \begin{tabular}{|l|l}
0,3 \\
5 \\
\end{tabular} \\
\hline 22 & 10 & 1 & 19 & 11 & 5 & 12 & 21 & 20 & 6 & $\begin{array}{l}15 \\
, 5 \\
\end{array}$ & 7 & 8 & 2 & 9 & 4 & 13 & 18 & $\begin{array}{c}15 \\
5\end{array}$ & 17 & 22 & 3 & 14 & $\begin{array}{ll}0,5 \\
4 \\
\end{array}$ \\
\hline 23 & 1 & 2 & 3 & 4 & 5 & 6 & 7 & 8 & 9 & 10 & 11 & 12 & 13 & 14 & 15 & 16 & 17 & 18 & 19 & 20 & 21 & 22 & \begin{tabular}{|l}
0,3 \\
8 \\
\end{tabular} \\
\hline 24 & 9 & 1 & 10 & 11 & 3 & 2 & 13 & 12 & 15 & 19 & 8 & 7 & 14 & 18 & 20 & 4 & 17 & 22 & 16 & 21 & 5 & 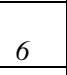 & \begin{tabular}{|l}
0.6 \\
9
\end{tabular} \\
\hline 25 & 20 & 4 & 11 & 18 & 5 & 6 & 2 & 17 & 15 & 16 & 1 & 8 & 10 & 14 & 13 & 7 & 12 & 22 & 9 & 21 & 3 & 19 & \begin{tabular}{|l}
0,2 \\
8 \\
\end{tabular} \\
\hline 26 & 3 & 1 & 10 & 14 & 4 & 5 & 12 & 7 & 19 & 17 & 6 & 2 & 13 & 22 & 8 & 16 & 9 & 20 & 18 & 15 & 2 & 11 & \begin{tabular}{|l|}
0,6 \\
9
\end{tabular} \\
\hline 27 & 7 & 2 & 19 & 8 & 1 & 15 & 6 & 20 & 17 & 16 & 3 & 9 & 14 & 13 & 18 & 5 & 22 & 11 & 12 & 21 & 10 & 4 & \begin{tabular}{|l}
0,6 \\
9
\end{tabular} \\
\hline 28 & 8 & 3 & 16 & 9 & 1 & 17 & 6 & 7 & 19 & 18 & 2 & 10 & 15 & 20 & 14 & 4 & 22 & 12 & 13 & 21 & 11 & 5 & \begin{tabular}{|l}
0,6 \\
9 \\
\end{tabular} \\
\hline 29 & 4 & 11 & 7 & 10 & 1 & 9 & 2 & 17 & 14 & 21 & 8 & 19 & 6 & 20 & 13 & 22 & 3 & 18 & 12 & 16 & 5 & 15 & $\begin{array}{l}0,4 \\
1 \\
\end{array}$ \\
\hline 30 & 1 & 3 & 21 & 10 & 8 & 9 & 7 & 14 & 12 & 13 & 11 & 22 & 15 & 17 & 6 & 18 & 19 & 16 & 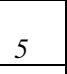 & 20 & 2 & 4 & \begin{tabular}{|l|}
0,6 \\
3
\end{tabular} \\
\hline 31 & 13 & 4 & 14 & 16 & 3 & 22 & 7 & 21 & 8 & 17 & 5 & 15 & 6 & 12 & 11 & 18 & 10 & 9 & 20 & 1 & 2 & 19 & \begin{tabular}{|l|l}
0,2 \\
6 \\
\end{tabular} \\
\hline 32 & 9 & 2 & 10 & 14 & 1 & 16 & 15 & 19 & 17 & 20 & 3 & 4 & 11 & 15 & 12 & 18 & $J$ & 21 & 7 & 22 & 0 & 8 & \begin{tabular}{|l|l}
0,4 \\
6 \\
\end{tabular} \\
\hline 33 & 1 & 9 & 10 & 12 & 11 & 7 & 6 & 5 & 15 & 14 & 13 & 17 & 16 & 18 & 19 & 8 & 21 & 4 & 22 & 20 & 3 & 2 & \begin{tabular}{|l|}
0,4 \\
2 \\
\end{tabular} \\
\hline 34 & 12 & 2 & 13 & 11 & 10 & 1 & 18 & 8 & 19 & 17 & 9 & 7 & 14 & 20 & 6 & 3 & 21 & 16 & 22 & 15 & 4 & 5 & $\begin{array}{l}0,6 \\
9\end{array}$ \\
\hline 35 & 4 & 3 & 15 & 5 & 6 & 7 & 14 & 16 & 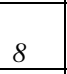 & 11 & 1 & 20 & 17 & 21 & 12 & 9 & 10 & 2 & 22 & 13 & 18 & 19 & \begin{tabular}{|l|}
0,3 \\
6 \\
\end{tabular} \\
\hline 36 & 2 & 4 & 11 & 12 & 1 & 14 & 19 & 20 & 21 & 5 & 18 & 17 & 6 & 22 & 7 & 8 & 10 & 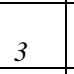 & 9 & 13 & 15 & 16 & \begin{tabular}{|l|}
0,2 \\
3 \\
\end{tabular} \\
\hline 37 & 10 & 9 & 17 & 11 & 4 & 5 & 15 & 14 & 16 & 13 & 1 & 2 & 19 & 22 & 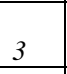 & 18 & 6 & 7 & 8 & 12 & 20 & 21 & \begin{tabular}{|l|l|}
0,2 \\
0 \\
\end{tabular} \\
\hline 38 & 1 & 8 & 9 & 7 & 5 & 15 & 12 & 11 & 14 & 13 & 5 & 10 & 2 & 16 & 18 & 5 & 17 & 20 & 19 & 21 & 3 & 22 & \begin{tabular}{|l|l}
0,4 \\
8 \\
\end{tabular} \\
\hline 39 & 2 & 5 & 16 & 10 & 9 & 15 & 19 & 11 & 8 & 7 & 1 & 18 & 6 & 1 & 14 & 22 & 12 & 17 & 4 & 20 & 3 & 13 & \begin{tabular}{|l|}
0,4 \\
5 \\
\end{tabular} \\
\hline 40 & 1 & 2 & 17 & 14 & 15 & 16 & 8 & 18 & 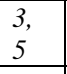 & $\begin{array}{l}3, \\
5\end{array}$ & $\begin{array}{l}5, \\
5 \\
\end{array}$ & 9 & 7 & 5 & 10 & 11 & 12 & 13 & 20 & 19 & 22 & 21 & \begin{tabular}{|l|l|}
0,2 \\
5 \\
\end{tabular} \\
\hline 41 & 1 & 3 & 22 & 4 & 2 & 5 & 6 & 13 & 15 & 16 & 17 & 18 & 7 & 19 & 20 & 8 & 9 & 10 & 11 & 12 & 21 & 14 & \begin{tabular}{|l|l|}
0,4 \\
0 \\
\end{tabular} \\
\hline 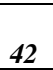 & 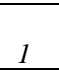 & 18 & 10 & 17 & - & 13 & 16 & 19 & 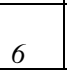 & - & 15 & & 14 & & & & & & 21 & & 22 & & \begin{tabular}{|l|}
0,2 \\
0 \\
\end{tabular} \\
\hline
\end{tabular}




\begin{tabular}{|c|c|c|c|c|c|c|}
\hline \multirow{4}{*}{ Impact Factor: } & ISRA (India) & $=3.117$ & SIS (USA) & $=0.912$ & ICV (Poland) & $=6.630$ \\
\hline & ISI (Dubai, UAE & $=0.829$ & РИНЦ (Russia & $=0.156$ & PIF (India) & $=1.940$ \\
\hline & GIF (Australia) & $=0.564$ & ESJI (KZ) & $=8.716$ & IBI (India) & $=4.260$ \\
\hline & JIF & $=1.500$ & SJIF (Morocce & $=5.667$ & OAJI (USA) & $=0.350$ \\
\hline
\end{tabular}

\begin{tabular}{|c|c|c|c|c|c|c|c|c|c|c|c|c|c|c|c|c|c|c|c|c|c|c|c|}
\hline 43 & 21 & $\begin{array}{l}17 \\
, 5\end{array}$ & $\begin{array}{l}8 \\
5 \\
5\end{array}$ & 15 & 16 & 19 & 21 & 21 & $\begin{array}{l}2, \\
5\end{array}$ & 11 & $\begin{array}{l}2, \\
5\end{array}$ & $\begin{array}{l}8, \\
5\end{array}$ & $\begin{array}{l}2, \\
5\end{array}$ & 13 & $\begin{array}{l}8, \\
5\end{array}$ & $\begin{array}{l}8, \\
5\end{array}$ & $\begin{array}{l}5, \\
5\end{array}$ & $\begin{array}{l}2, \\
5\end{array}$ & $\begin{array}{l}5, \\
5\end{array}$ & $\begin{array}{l}17 \\
, 5\end{array}$ & 13 & 13 & $\begin{array}{l}0,1 \\
7\end{array}$ \\
\hline 44 & $\begin{array}{l}21 \\
5\end{array}$ & $\begin{array}{l}8, \\
5\end{array}$ & 12 & $\begin{array}{l}21 \\
.5\end{array}$ & 17 & 18 & 19 & $\begin{array}{l}8, \\
5\end{array}$ & 4 & 20 & 4 & 4 & 4 & 12 & 4 & 4 & 15 & 4 & 10 & 15 & 15 & 12 & $\begin{array}{l}0,1 \\
9,\end{array}$ \\
\hline 45 & 11 & 4 & 18 & 5 & 1 & 2 & 3 & 16 & 17 & 20 & 6 & 19 & 10 & 9 & 15 & 14 & 21 & 12 & 13 & 22 & 7 & 8 & \\
\hline 46 & 4 & 2 & 21 & 7 & 18 & 17 & 12 & 6 & 11 & 10 & 5 & 1 & 19 & 9 & 8 & 15 & 22 & 14 & 16 & 20 & 13 & 3 & $\begin{array}{l}0,3 \\
2\end{array}$ \\
\hline 47 & 3 & 13 & 18 & 9 & 14 & 1 & 2 & 4 & $\begin{array}{l}6, \\
5 \\
\end{array}$ & $\begin{array}{l}21 \\
, 5 \\
\end{array}$ & $\begin{array}{l}10 \\
5 \\
\end{array}$ & 5 & 15 & $\begin{array}{l}10 \\
, 5 \\
\end{array}$ & 8 & $\begin{array}{l}21 \\
5\end{array}$ & $\begin{array}{l}6, \\
5 \\
\end{array}$ & 16 & 20 & 19 & 17 & 12 & $\begin{array}{l}0,2 \\
7\end{array}$ \\
\hline 48 & 8 & 5 & 17 & 6 & $\begin{array}{l}3, \\
5\end{array}$ & 18 & $\begin{array}{l}9, \\
5\end{array}$ & $\begin{array}{l}9, \\
5 \\
\end{array}$ & 7 & 12 & 11 & 14 & 2 & 13 & $\begin{array}{l}3, \\
5\end{array}$ & 22 & 21 & 15 & 16 & 20 & 19 & 1 & $\begin{array}{l}0,5 \\
1\end{array}$ \\
\hline 49 & $\begin{array}{l}6, \\
5 \\
\end{array}$ & 5 & 16 & $\begin{array}{l}6, \\
5 \\
\end{array}$ & $\begin{array}{l}19 \\
, 5 \\
\end{array}$ & 8 & $\begin{array}{r}21 \\
5 \\
\end{array}$ & 3 & 9 & $\begin{array}{r}21 \\
, 5 \\
\end{array}$ & 10 & 15 & 2 & 14 & 17 & $\begin{array}{r}19 \\
.5 \\
\end{array}$ & 4 & 11 & 13 & 18 & 12 & 1 & $\begin{array}{l}0,3 \\
2 \\
\end{array}$ \\
\hline 50 & 17 & 14 & 21 & 1 & 22 & 8 & 9 & 20 & 5 & 7 & 6 & 10 & 12 & 13 & 11 & 15 & 2 & 16 & 18 & 19 & 3 & 4 & $\begin{array}{l}0,2 \\
1\end{array}$ \\
\hline 51 & 13 & 1 & 22 & 15 & 9 & 8 & 21 & 6 & 10 & 7 & 12 & 11 & 16 & 14 & 17 & 2 & 20 & 18 & 19 & 5 & 4 & 3 & $\begin{array}{l}0,3 \\
0 \\
\end{array}$ \\
\hline 52 & 3 & 1 & 22 & 12 & 4 & 9 & 8 & 10 & 5 & 15 & 6 & 13 & 16 & 14 & 11 & 17 & 20 & 7 & 18 & 19 & 21 & 2 & $\begin{array}{l}0,6 \\
0\end{array}$ \\
\hline 53 & 15 & 18 & 19 & 13 & 6 & 7 & 3 & $\begin{array}{l}20 \\
, 5 \\
\end{array}$ & 8 & 17 & $\begin{array}{l}1, \\
5\end{array}$ & 12 & 16 & 11 & 22 & 5 & $\begin{array}{l}20 \\
, 5\end{array}$ & 4 & 9 & 14 & 10 & $\begin{array}{l}1, \\
5\end{array}$ & $\begin{array}{l}0,2 \\
2\end{array}$ \\
\hline 54 & 8 & 1 & 21 & 2 & 10 & 4 & 13 & 12 & 5 & 20 & 19 & 6 & 18 & 7 & 22 & 9 & 17 & 16 & 15 & 14 & 3 & 11 & $\begin{array}{l}0,3 \\
1\end{array}$ \\
\hline 55 & 10 & 11 & 16 & 17 & 12 & 21 & 14 & 22 & 13 & $\begin{array}{l}1, \\
5\end{array}$ & $\begin{array}{l}1, \\
5\end{array}$ & 15 & 18 & $\begin{array}{l}3, \\
5 \\
\end{array}$ & 19 & 20 & $\begin{array}{l}3, \\
5 \\
\end{array}$ & $\begin{array}{l}7, \\
5 \\
\end{array}$ & 6 & 5 & $\begin{array}{l}7, \\
5\end{array}$ & 9 & $\begin{array}{l}0,1 \\
8\end{array}$ \\
\hline $\begin{array}{l}\text { CyM } \\
\text { Mbl } \\
\text { panz } \\
\text { oв }\end{array}$ & $\begin{array}{l}39 \\
3\end{array}$ & $\begin{array}{l}36 \\
8 \\
5\end{array}$ & $\begin{array}{l}76 \\
5 \\
5\end{array}$ & $\begin{array}{l}55 \\
9\end{array}$ & $\begin{array}{l}45 \\
5 \\
\end{array}$ & $\begin{array}{l}58 \\
3\end{array}$ & $\begin{array}{l}60 \\
0, \\
5\end{array}$ & $\begin{array}{l}67 \\
9, \\
5\end{array}$ & $\begin{array}{l}63 \\
4, \\
5\end{array}$ & $\begin{array}{l}77 \\
2 \\
\end{array}$ & $\begin{array}{l}44 \\
0, \\
5\end{array}$ & $\begin{array}{l}73 \\
2 \\
\end{array}$ & $\begin{array}{l}51 \\
6, \\
5\end{array}$ & $\begin{array}{l}81 \\
5, \\
5\end{array}$ & $\begin{array}{l}67 \\
0\end{array}$ & $\begin{array}{l}71 \\
5 \\
5\end{array}$ & $\begin{array}{l}77 \\
8 \\
\end{array}$ & $\begin{array}{l}72 \\
3, \\
5\end{array}$ & $\begin{array}{l}81 \\
9, \\
5\end{array}$ & $\begin{array}{l}81 \\
4\end{array}$ & $\begin{array}{l}56 \\
3 \\
\end{array}$ & $\begin{array}{l}51 \\
6, \\
5\end{array}$ & \\
\hline $\begin{array}{l}\text { Бes } \\
\text { epe } \\
\text { muк } \\
\text { ов. }\end{array}$ & 47 & 12 & 76 & 44 & 16 & 37 & 46 & 63 & 87 & 90 & 28 & 52 & 67 & 80 & 73 & 30 & $\begin{array}{l}10 \\
3\end{array}$ & 73 & 76 & $\begin{array}{l}10 \\
0\end{array}$ & 37 & 28 & \\
\hline $\begin{array}{l}\text { Ko } \\
\phi . \\
\text { кon } \\
\text { кop } \\
\text { d. }\end{array}$ & & $\begin{array}{l}0, \\
16\end{array}$ & & $\begin{array}{l}0, \\
69\end{array}$ & & & & & & & & & & & & & & & & & & & \\
\hline $\begin{array}{l}\text { Kpu } \\
\text { mep } \\
\text { uй } \\
\text { Iup } \\
\text { cö } \\
\text { a. }\end{array}$ & & $\begin{array}{l}18 \\
3, \\
2\end{array}$ & & $\begin{array}{l}6, \\
55\end{array}$ & & & & & & & & & & & & & & & & & & & \\
\hline
\end{tabular}

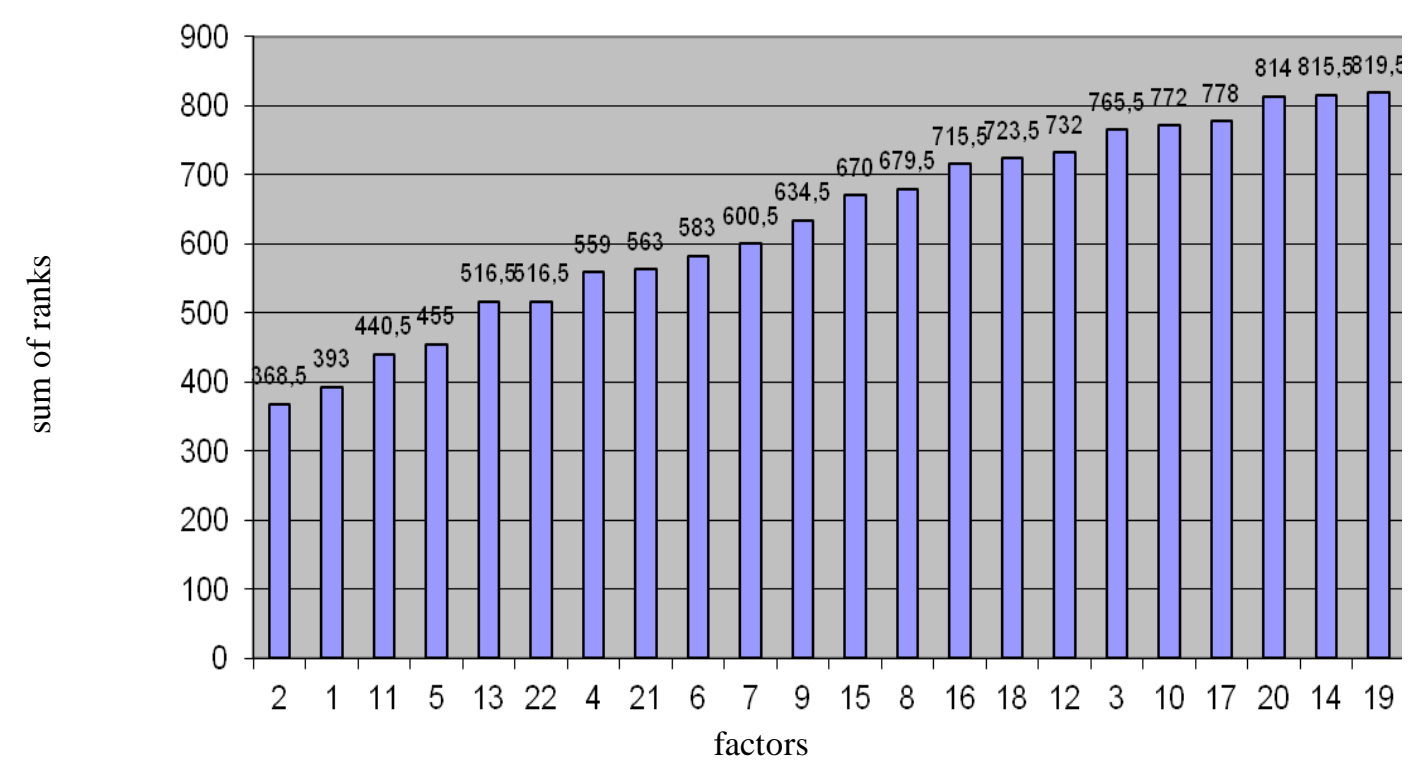

Picture 1 - The results of processing of questioning children that participated in the survey for assessing the competitiveness of and demand for children's shoes 


\begin{tabular}{llllll} 
& ISRA (India) $=\mathbf{3 . 1 1 7}$ & SIS (USA) & $=\mathbf{0 . 9 1 2}$ & ICV (Poland) & $=\mathbf{6 . 6 3 0}$ \\
Impact Factor: & ISI (Dubai, UAE) $=\mathbf{0 . 8 2 9}$ & PUHL (Russia) $=\mathbf{0 . 1 5 6}$ & PIF (India) & $=\mathbf{1 . 9 4 0}$ \\
& GIF (Australia) $=\mathbf{0 . 5 6 4}$ & ESJI (KZ) & $=\mathbf{8 . 7 1 6}$ & IBI (India) & $=\mathbf{4 . 2 6 0}$ \\
& JIF & $\mathbf{1 . 5 0 0}$ & SJIF (Morocco) $=\mathbf{5 . 6 6 7}$ & OAJI (USA) & $\mathbf{0 . 3 5 0}$ \\
\hline
\end{tabular}

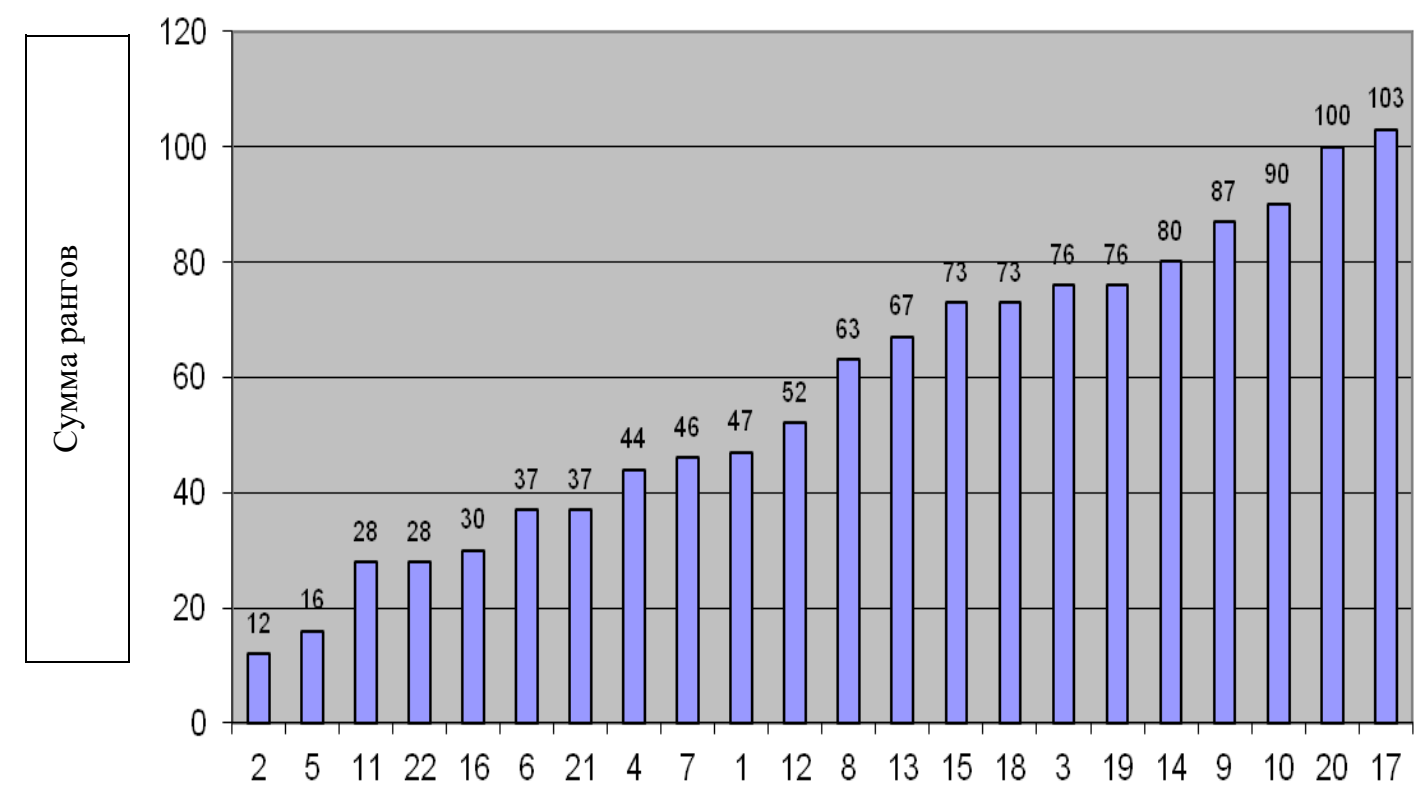

factors

Figure 2 - The results of processing of questioning children that participated in the survey for assessing the competitiveness of and demand for children's shoes, without heretics, that is, whose opinion is not consistent with the majority of survey participants

Table 4 - Criteria for assessing the competitiveness of and demand for children's shoes eyes of ordinary buyers

\begin{tabular}{|l|l|l|}
\hline number & $\begin{array}{l}\text { The list of factors to evaluate the competitive capacity of enterprises and regions of the } \\
\text { Southern Federal District North Caucasus Federal District in the production of } \\
\text { children's shoes }\end{array}$ & (Weight \\
\hline one & Colour & \\
\hline 2 & Quality children's shoes & \\
\hline 3 & Functionality of children's shoes & \\
\hline four & Characterization of materials for shoe uppers & \\
\hline five & Compliance towards fashion & \\
\hline 6 & Price & \\
\hline 7 & Characterization of materials for the bottom of shoes & \\
\hline 9 & comfort & \\
\hline ten & Elation heel height of the shoe - 40 mm & \\
\hline eleven & Elation heel height of the shoe 40 mm -svyshe & \\
\hline 12 & repairability & \\
\hline 13 & The warranty period for children's shoes & \\
\hline 14 & What types of children's shoes are preferred: Winter & \\
\hline 15 & autumn & \\
\hline sixteen & spring & \\
\hline 17 & summer & \\
\hline 18 & Durability fastening shoe bottom & \\
\hline
\end{tabular}

Table 5 - Results of the survey processing customers who participated in the survey for assessing the competitiveness of and demand for children's shoes

\begin{tabular}{|c|c|c|c|c|c|c|c|c|c|c|c|c|c|c|c|c|c|c|c|}
\hline $\begin{array}{l}\text { Фактор } \\
\text { Эксперт }\end{array}$ & X1 & $\mathbf{X} 2$ & X3 & X4 & X5 & X6 & $\mathbf{X} 7$ & X8 & X9 & $\begin{array}{l}X \\
10\end{array}$ & $\begin{array}{l}\mathbf{X} \\
\mathbf{1 1}\end{array}$ & $\begin{array}{l}X \\
12\end{array}$ & $\begin{array}{l}X \\
13\end{array}$ & $\begin{array}{l}X \\
14\end{array}$ & $\begin{array}{l}X \\
15\end{array}$ & $\begin{array}{l}X \\
16\end{array}$ & $\begin{array}{l}X \\
17\end{array}$ & $\begin{array}{l}X \\
18\end{array}$ & Кк \\
\hline Phi & ade & & SA & & & & & & 752 & & & & & & & & & & \\
\hline
\end{tabular}




\begin{tabular}{llllll} 
& ISRA (India) $=\mathbf{3 . 1 1 7}$ & SIS (USA) $=\mathbf{0 . 9 1 2}$ & ICV (Poland) & $\mathbf{= 6 . 6 3 0}$ \\
Impact Factor: & ISI (Dubai, UAE) $=\mathbf{0 . 8 2 9}$ & PUHЦ (Russia) $=\mathbf{0 . 1 5 6}$ & PIF (India) & $=\mathbf{1 . 9 4 0}$ \\
& GIF (Australia) $=\mathbf{0 . 5 6 4}$ & ESJI (KZ) & $\mathbf{8 . 7 1 6}$ & IBI (India) & $=\mathbf{4 . 2 6 0}$ \\
& JIF & $=\mathbf{1 . 5 0 0}$ & SJIF (Morocco) $=\mathbf{5 . 6 6 7}$ & OAJI (USA) & $\mathbf{0 . 3 5 0}$ \\
\hline
\end{tabular}

\begin{tabular}{|c|c|c|c|c|c|c|c|c|c|c|c|c|c|c|c|c|c|c|c|}
\hline 1 & 13 & 11 & 9 & 1 & 2 & 6 & 3 & 5 & 7 & 4 & 12 & 14 & 8 & 17 & 15 & 18 & 16 & 10 & 0,60 \\
\hline 2 & 4 & 18 & 5 & 17 & 1 & 16 & 3 & 13 & 2 & 12 & 11 & 15 & 14 & 8 & 7 & 9 & 10 & 6 & 0,52 \\
\hline 3 & 3 & 2 & 4 & 9 & 10 & 1 & 5 & 6 & 8 & 11 & 17 & 12 & 7 & 13 & 16 & 15 & 14 & 18 & 0,59 \\
\hline 4 & 8 & 13 & 4 & 3 & 9 & 1 & 10 & 12 & 2 & 5 & 14 & 6 & 7 & 15 & 16 & 17 & 18 & 11 & 0,64 \\
\hline 5 & 4 & 3 & 5 & 7 & 2 & 1 & 6 & 12 & 8 & 9 & 10 & 13 & 15 & 14 & 18 & 17 & 16 & 11 & 0,68 \\
\hline 6 & 5 & 13 & 1 & 3 & 4 & 2 & 11 & 12 & 6 & 7 & 18 & 9 & 8 & 14 & 15 & 16 & 17 & 10 & 0,66 \\
\hline 7 & 1 & 9 & 4 & 3 & 8 & 10 & 5 & 6 & 2 & 11 & 13 & 12 & 15 & 14 & 16 & 18 & 17 & 7 & 0,71 \\
\hline 8 & 11 & 12 & 3 & 2 & 9 & 10 & 4 & 5 & 1 & 13 & 15 & 6 & 7 & 14 & 16 & 17 & 18 & 8 & 0,60 \\
\hline 9 & 18 & 17 & 1 & 2 & 5 & 3 & 4 & 6 & 7 & 10 & 11 & 8 & 12 & 16 & 14 & 13 & 15 & 9 & 0,61 \\
\hline 10 & 4 & 3 & 16 & 5 & 7 & 1 & 2 & 8 & 9 & 10 & 11 & 12 & 14 & 13 & 18 & 17 & 6 & 15 & 0,54 \\
\hline 11 & 11 & 4 & 3 & 10 & 12 & 13 & 2 & 1 & 9 & 8 & 15 & 14 & 17 & 16 & 6 & 5 & 7 & 18 & 0,50 \\
\hline 12 & 5 & 11 & 1 & 4 & 9 & 10 & 3 & 7 & 2 & 12 & 13 & 6 & 14 & 8 & 16 & 17 & 18 & 15 & 0,72 \\
\hline 13 & 2 & 4 & 1 & 5 & 7 & 3 & 8 & 11 & 6 & 12 & 9 & 10 & 13 & 15 & 14 & 17 & 16 & 18 & 0,69 \\
\hline 14 & 6 & 9 & 8 & 2 & 3 & 5 & 7 & 11 & 4 & 10 & 13 & 1 & 12 & 14 & 16 & 17 & 15 & 18 & 0,63 \\
\hline 15 & 3 & 2 & 4 & 5 & 7 & 9 & 11 & 10 & 12 & 6 & 13 & 1 & 14 & 8 & 15 & 16 & 18 & 17 & 0,53 \\
\hline 16 & 4 & 11 & 3 & 10 & 16 & 1 & 9 & 15 & 2 & 17 & 5 & 14 & 18 & 7 & 6 & 12 & 13 & 8 & 0,56 \\
\hline 17 & 5 & 13 & 1 & 6 & 11 & 2 & 3 & 12 & 4 & 18 & 9 & 10 & 16 & 15 & 7 & 14 & 17 & 8 & 0,84 \\
\hline 18 & 6 & 7 & 8 & 11 & 12 & 5 & 2 & 13 & 1 & 14 & 4 & 17 & 18 & 9 & 3 & 15 & 16 & 10 & 0,57 \\
\hline 19 & 10 & 9 & 5 & 4 & 8 & 1 & 7 & 11 & 3 & 14 & 6 & 17 & 18 & 13 & 2 & 15 & 16 & 12 & 0,91 \\
\hline 20 & 15 & 14 & 6 & 5 & 3 & 1 & 7 & 4 & 2 & 8 & 13 & 16 & 17 & 10 & 9 & 11 & 18 & 12 & 0,78 \\
\hline 21 & 10 & 15 & 1 & 2 & 5 & 6 & 8 & 16 & 3 & 4 & 17 & 18 & 12 & 9 & 7 & 14 & 13 & 11 & 0,65 \\
\hline 22 & 7 & 12 & 2 & 6 & 4 & 1 & 11 & 5 & 3 & 18 & 8 & 13 & 17 & 10 & 9 & 14 & 15 & 16 & 0,89 \\
\hline 23 & 7 & 10 & 2 & 6 & 4 & 3 & 9 & 5 & 1 & 11 & 14 & 15 & 18 & 12 & 13 & 16 & 17 & 8 & 0,81 \\
\hline 24 & 7 & 9 & 6 & 8 & 10 & 1 & 2 & 11 & 3 & 12 & 13 & 17 & 18 & 5 & 4 & 14 & 15 & 16 & 0,91 \\
\hline 25 & 5 & 13 & 6 & 12 & 4 & 2 & 1 & 11 & 3 & 10 & 18 & 14 & 17 & 8 & 15 & 16 & 9 & 7 & 0,67 \\
\hline 26 & 5 & 3 & 4 & 11 & 13 & 1 & 2 & 12 & 6 & 15 & 7 & 14 & 18 & 10 & 8 & 9 & 17 & 16 & 0,59 \\
\hline 27 & 8 & 16 & 2 & 3 & 5 & 7 & 1 & 6 & 4 & 10 & 17 & 9 & 18 & 11 & 14 & 13 & 15 & 12 & 0,76 \\
\hline 28 & 13 & 6 & 1 & 5 & 17 & 2 & 3 & 14 & 4 & 15 & 18 & 7 & 16 & 9 & 8 & 11 & 10 & 12 & 0,56 \\
\hline 29 & 8 & 17 & 1 & 5 & 9 & 3 & 2 & 7 & 4 & 10 & 18 & 6 & 12 & 14 & 13 & 15 & 16 & 11 & 0,73 \\
\hline 30 & 5 & 13 & 2 & 10 & 9 & 3 & 4 & 12 & 1 & 11 & 8 & 17 & 18 & 7 & 6 & 14 & 15 & 16 & 0,91 \\
\hline 31 & 6 & 9 & 8 & 2 & 3 & 5 & 7 & 11 & 4 & 10 & 13 & 1 & 12 & 14 & 16 & 17 & 15 & 18 & 0,62 \\
\hline 32 & 2 & 4 & 1 & 5 & 7 & 3 & 8 & 11 & 6 & 12 & 9 & 10 & 13 & 15 & 14 & 17 & 16 & 18 & 0,69 \\
\hline 33 & 11 & 4 & 3 & 10 & 12 & 13 & 2 & 1 & 9 & 8 & 15 & 14 & 17 & 16 & 6 & 5 & 7 & 18 & 0,49 \\
\hline 34 & 18 & 17 & 1 & 2 & 5 & 3 & 4 & 6 & 7 & 10 & 11 & 8 & 12 & 16 & 14 & 13 & 15 & 9 & 0,61 \\
\hline 35 & 1 & 9 & 4 & 3 & 8 & 10 & 5 & 6 & 2 & 11 & 13 & 12 & 15 & 14 & 16 & 18 & 17 & 7 & 0,70 \\
\hline 36 & 4 & 3 & 5 & 7 & 2 & 1 & 6 & 12 & 8 & 9 & 10 & 13 & 15 & 14 & 18 & 17 & 16 & 11 & 0,67 \\
\hline 37 & 8 & 13 & 4 & 3 & 9 & 1 & 10 & 12 & 2 & 5 & 14 & 6 & 7 & 15 & 16 & 17 & 18 & 11 & 0,63 \\
\hline 38 & 13 & 11 & 9 & 1 & 2 & 6 & 3 & 5 & 7 & 4 & 12 & 14 & 8 & 17 & 15 & 18 & 16 & 10 & 0,60 \\
\hline 39 & 4 & 18 & 5 & 17 & 1 & 16 & 3 & 13 & 2 & 12 & 11 & 15 & 14 & 8 & 7 & 9 & 10 & 6 & 0,53 \\
\hline 40 & 5 & 13 & 2 & 10 & 9 & 3 & 4 & 12 & 1 & 11 & 8 & 17 & 18 & 7 & 6 & 14 & 15 & 16 & 0,91 \\
\hline 41 & 13 & 6 & 1 & 5 & 17 & 2 & 3 & 14 & 4 & 15 & 7 & 16 & 9 & 8 & 11 & 10 & 12 & 18 & 0,55 \\
\hline 42 & 8 & 16 & 2 & 3 & 5 & 7 & 1 & 6 & 4 & 10 & 17 & 9 & 18 & 11 & 14 & 13 & 15 & 12 & 0,74 \\
\hline 43 & 5 & 3 & 4 & 11 & 13 & 1 & 2 & 12 & 6 & 15 & 7 & 14 & 18 & 10 & 8 & 9 & 17 & 16 & 0,58 \\
\hline 44 & 5 & 13 & 6 & 12 & 4 & 2 & 1 & 11 & 3 & 10 & 18 & 14 & 17 & 8 & 15 & 16 & 9 & 7 & 0,66 \\
\hline 45 & 7 & 9 & 6 & 8 & 10 & 1 & 2 & 11 & 3 & 12 & 13 & 17 & 18 & 5 & 4 & 14 & 15 & 16 & 0,91 \\
\hline 46 & 7 & 10 & 2 & 6 & 4 & 3 & 9 & 5 & 1 & 11 & 14 & 15 & 18 & 12 & 13 & 16 & 17 & 8 & 0,79 \\
\hline 47 & 7 & 12 & 2 & 6 & 4 & 1 & 11 & 5 & 3 & 18 & 8 & 13 & 17 & 10 & 9 & 14 & 15 & 16 & 0,86 \\
\hline 48 & 10 & 15 & 1 & 2 & 5 & 6 & 8 & 16 & 3 & 4 & 17 & 18 & 12 & 9 & 7 & 14 & 13 & 11 & 0,64 \\
\hline 49 & 15 & 14 & 6 & 5 & 3 & 1 & 7 & 4 & 2 & 8 & 13 & 16 & 17 & 10 & 9 & 11 & 18 & 12 & 0,77 \\
\hline 50 & 10 & 9 & 5 & 4 & 8 & 1 & 7 & 11 & 3 & 14 & 6 & 17 & 18 & 13 & 2 & 15 & 16 & 12 & 0,91 \\
\hline 51 & 6 & 7 & 8 & 11 & 12 & 5 & 2 & 13 & 1 & 14 & 4 & 17 & 18 & 9 & 3 & 15 & 16 & 10 & 0,57 \\
\hline
\end{tabular}




\begin{tabular}{|c|c|c|c|c|c|c|}
\hline \multirow{4}{*}{ Impact Factor: } & ISRA (India) & $=3.117$ & SIS (USA) & $=0.912$ & ICV (Poland) & $=6.630$ \\
\hline & ISI (Dubai, UAE & $=0.829$ & РИНЦ (Russia & $=0.156$ & PIF (India) & $=1.940$ \\
\hline & GIF (Australia) & $=0.564$ & ESJI (KZ) & $=8.716$ & IBI (India) & $=4.260$ \\
\hline & JIF & $=1.500$ & SJIF (Morocce & $=5.667$ & OAJI (USA) & $=0.350$ \\
\hline
\end{tabular}

\begin{tabular}{|c|c|c|c|c|c|c|c|c|c|c|c|c|c|c|c|c|c|c|c|}
\hline 52 & 5 & 13 & 1 & 6 & 11 & 2 & 3 & 12 & 4 & 18 & 9 & 10 & 16 & 15 & 7 & 14 & 17 & 8 & 0,82 \\
\hline 53 & 4 & 11 & 3 & 10 & 16 & 1 & 9 & 15 & 2 & 17 & 5 & 14 & 18 & 7 & 6 & 12 & 13 & 8 & 0,55 \\
\hline $\begin{array}{l}\text { Суммы } \\
\text { рангов }\end{array}$ & $\begin{array}{l}38 \\
7 \\
\end{array}$ & $\begin{array}{l}53 \\
8 \\
\end{array}$ & $\begin{array}{l}20 \\
8 \\
\end{array}$ & $\begin{array}{l}33 \\
1 \\
\end{array}$ & $\begin{array}{l}39 \\
5 \\
\end{array}$ & $\begin{array}{l}22 \\
4 \\
\end{array}$ & $\begin{array}{l}27 \\
2 \\
\end{array}$ & $\begin{array}{l}50 \\
3 \\
\end{array}$ & $\begin{array}{l}21 \\
6 \\
\end{array}$ & $\begin{array}{l}58 \\
5 \\
\end{array}$ & $\begin{array}{l}62 \\
4 \\
\end{array}$ & $\begin{array}{l}64 \\
3 \\
\end{array}$ & $\begin{array}{l}77 \\
3 \\
\end{array}$ & $\begin{array}{l}61 \\
1 \\
\end{array}$ & $\begin{array}{l}57 \\
8 \\
\end{array}$ & $\begin{array}{l}75 \\
0 \\
\end{array}$ & $\begin{array}{l}78 \\
1 \\
\end{array}$ & $\begin{array}{l}64 \\
4 \\
\end{array}$ & \\
\hline $\begin{array}{l}\text { Сумма } \\
\text { рангов } \\
\text { без } \\
\text { еретико } \\
\text { в } \\
\end{array}$ & 34 & 53 & 21 & 40 & 46 & 9 & 16 & 57 & 11 & 60 & 48 & 85 & 90 & 37 & 22 & 71 & 76 & 76 & \\
\hline $\begin{array}{l}\text { Коэф. } \\
\text { конкорд }\end{array}$ & & $\begin{array}{l}0,4 \\
74 \\
\end{array}$ & & $\begin{array}{l}0,9 \\
07\end{array}$ & & & & & & & & & & & & & & & \\
\hline $\begin{array}{l}\text { Крит. } \\
\text { Пирсона }\end{array}$ & & $\begin{array}{l}42 \\
7,6 \\
\end{array}$ & & 7,3 & & & & & & & & & & & & & & & \\
\hline
\end{tabular}

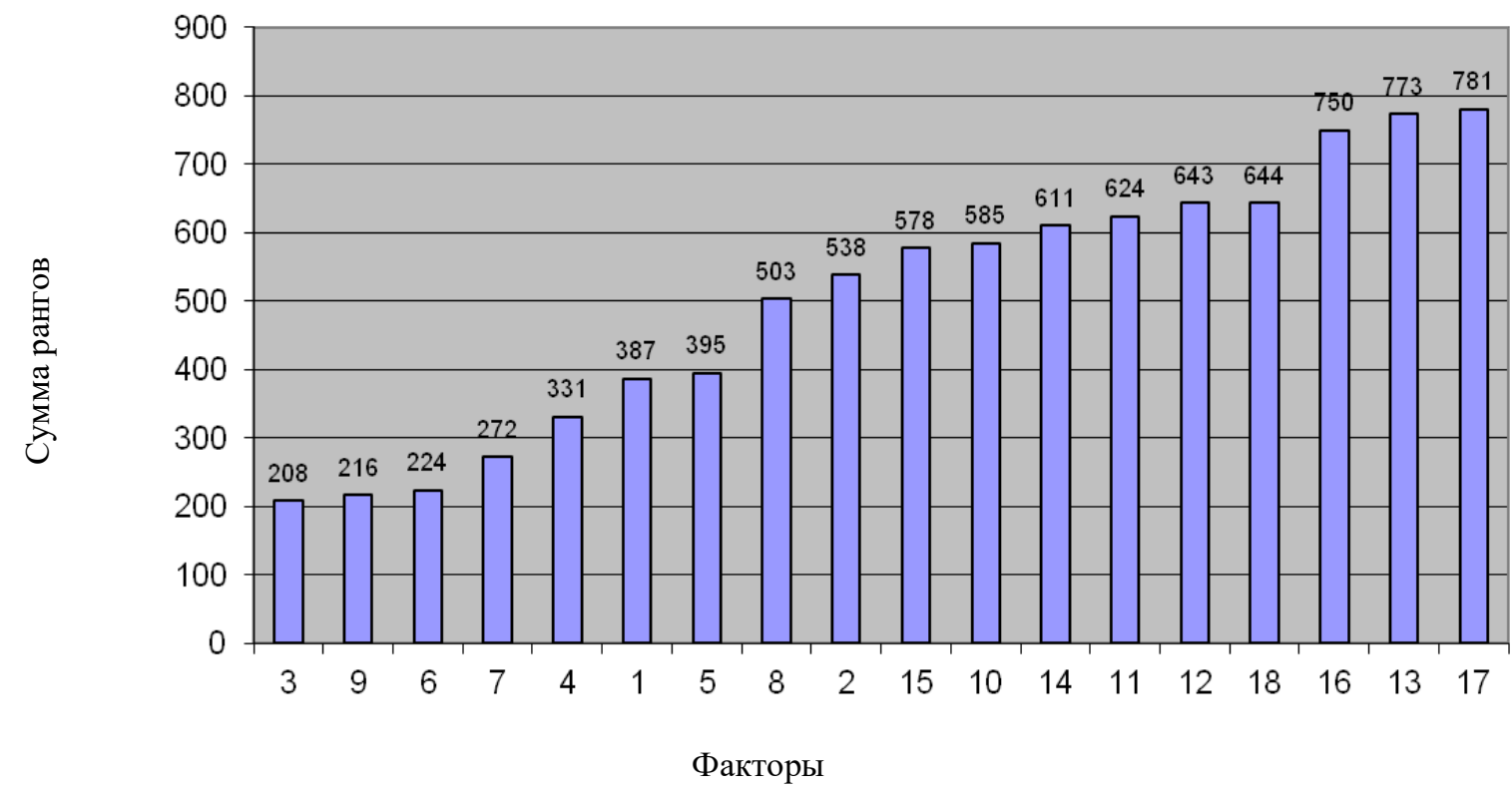

Figure 3 -The results of processing the survey buyers who participated in the survey for assessing the competitiveness of and demand for children's shoes

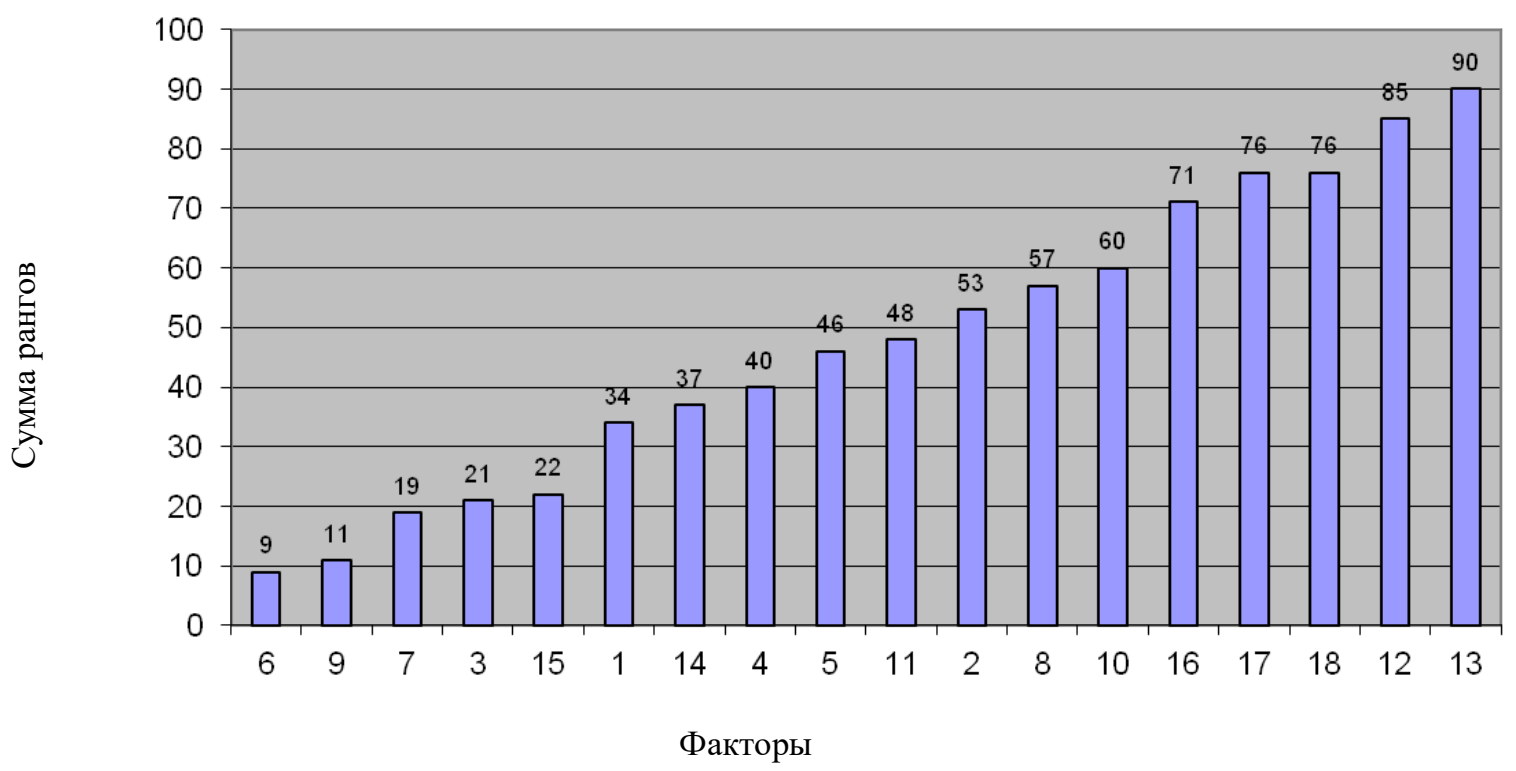

Figure 4 -The results of processing the survey buyers who participated in the survey for assessing the competitiveness of and demand for children's shoes without heretics, that is, whose opinion is not consistent with the majority of survey participants 


\begin{tabular}{llllll} 
& ISRA (India) $=\mathbf{3 . 1 1 7}$ & SIS (USA) & $=\mathbf{0 . 9 1 2}$ & ICV (Poland) & $=\mathbf{6 . 6 3 0}$ \\
Impact Factor: & ISI (Dubai, UAE) $=\mathbf{0 . 8 2 9}$ & PUHL (Russia) $=\mathbf{0 . 1 5 6}$ & PIF (India) & $=\mathbf{1 . 9 4 0}$ \\
& GIF (Australia) $=\mathbf{0 . 5 6 4}$ & ESJI (KZ) & $=\mathbf{8 . 7 1 6}$ & IBI (India) & $=\mathbf{4 . 2 6 0}$ \\
& JIF & $\mathbf{1 . 5 0 0}$ & SJIF (Morocco) $=\mathbf{5 . 6 6 7}$ & OAJI (USA) & $\mathbf{0 . 3 5 0}$ \\
\hline
\end{tabular}

Table 6 - Criteria for assessing the competitiveness of and demand for the eyes of children's shoes companies footwear manufacturers SFD and North Caucasus Federal District regions

\begin{tabular}{|l|l|l|}
\hline number & $\begin{array}{l}\text { The list of factors to evaluate the competitive capacity of enterprises and regions of the } \\
\text { Southern Federal District North Caucasus Federal District in the production of } \\
\text { children's shoes }\end{array}$ & Rank \\
\hline one & Weight & \\
\hline 2 & Colour & \\
\hline 3 & Quality children's shoes & \\
\hline four & Functionality of children's shoes & \\
\hline five & Characterization of materials for shoe uppers & \\
\hline 6 & Compliance towards fashion & \\
\hline 7 & Price & \\
\hline eight & Characterization of materials for the bottom of shoes & \\
\hline 9 & comfort & \\
\hline ten & Elation heel height of the shoe - 40 mm & \\
\hline eleven & Elation heel height of the shoe 40 mm -svyshe & \\
\hline 12 & repairability & \\
\hline 13 & The warranty period for children's shoes & \\
\hline
\end{tabular}

Table 7 - Results of the survey processing manufacturers who participated in the survey for assessing the competitiveness of and demand for children's shoes

\begin{tabular}{|c|c|c|c|c|c|c|c|c|c|c|c|c|c|c|}
\hline $\begin{array}{l}\text { Факт } \\
\text { ор } \\
\text { Эксп } \\
\text { ерт } \\
\end{array}$ & X1 & X2 & $\mathbf{X 3}$ & X4 & X5 & X6 & $\mathbf{X} 7$ & X8 & X9 & X10 & X11 & X12 & X13 & КК \\
\hline 1 & 7 & 10 & 1 & 2 & 8 & 6 & 4 & 9 & 3 & 11 & 13 & 5 & 12 & 0,84 \\
\hline 2 & 9 & 7 & 1 & 4 & 8 & 6 & 2 & 10 & 3 & 11 & 13 & 5 & 12 & 0,84 \\
\hline 3 & 1 & 3 & 5 & 2 & 8 & 7 & 4 & 9 & 12 & 6 & 13 & 11 & 10 & 0,5 \\
\hline 4 & 2 & 3 & 1 & 5 & 4 & 8 & 9 & 6 & 10 & 7 & 11 & 13 & 12 & 0,52 \\
\hline 5 & 9 & 10 & 6 & 7 & 8 & 2 & 1 & 4 & 3 & 5 & 11 & 12 & 13 & 0,65 \\
\hline 6 & 10 & 9 & 1 & 4 & 3 & 2 & 5 & 6 & 7 & 11 & 12 & 8 & 13 & 0,84 \\
\hline 7 & 5 & 6 & 1 & 9 & 10 & 13 & 7 & 8 & 2 & 12 & 11 & 4 & 3 & 0,46 \\
\hline 8 & 5 & 11 & 4 & 1 & 10 & 2 & 3 & 12 & 6 & 9 & 13 & 8 & 7 & 0,74 \\
\hline 9 & 2 & 7 & 4 & 5 & 6 & 1 & 9 & 3 & 8 & 12 & 13 & 11 & 10 & 0,60 \\
\hline 10 & 7 & 13 & 2 & 11 & 1 & 6 & 12 & 10 & 3 & 4 & 9 & 8 & 5 & 0,43 \\
\hline 11 & 9 & 13 & 5 & 1 & 2 & 4 & 3 & 6 & 7 & 8 & 12 & 10 & 11 & 0,81 \\
\hline 12 & 12 & 13 & 1 & 6 & 7 & 3 & 2 & 8 & 5 & 4 & 9 & 10 & 11 & 0,76 \\
\hline 13 & 5 & 8 & 2 & 4 & 7 & 10 & 1 & 12 & 11 & 13 & 3 & 9 & 6 & 0,45 \\
\hline 14 & 5 & 2 & 11 & 4 & 7 & 13 & 8 & 12 & 1 & 6 & 9 & 3 & 10 & 0,41 \\
\hline 15 & 10 & 13 & 2 & 4 & 6 & 5 & 3 & 11 & 1 & 7 & 12 & 8 & 9 & 0,84 \\
\hline 16 & 5 & 3 & 1 & 2 & 7 & 6 & 4 & 10 & 8 & 11 & 12 & 9 & 13 & 0,68 \\
\hline 17 & 3 & 4 & 1 & 7 & 9 & 8 & 5 & 10 & 2 & 11 & 13 & 12 & 6 & 0,62 \\
\hline 18 & 5 & 6,5 & 1 & 2 & 6,5 & 9 & 8 & 3 & 4 & 12 & 13 & 11 & 10 & 0,66 \\
\hline 19 & 9 & 13 & 2 & 4 & 7 & 5 & 6 & 3 & 1 & 8 & 10 & 12 & 11 & 0,78 \\
\hline 20 & 10 & 11 & 1 & 2 & 5 & 7 & 3 & 6 & 4 & 12 & 13 & 9 & 8 & 0,84 \\
\hline 21 & 3 & 8 & 4 & 6 & 10 & 5 & 12 & 7 & 1 & 13 & 9 & 2 & 11 & 0,48 \\
\hline 22 & 9 & 8 & 2 & 7 & 5 & 6 & 1 & 10 & 3 & 11 & 12 & 13 & 4 & 0,72 \\
\hline
\end{tabular}




\begin{tabular}{|c|c|c|c|c|c|c|}
\hline \multirow{4}{*}{ Impact Factor: } & ISRA (India) & $=3.117$ & SIS (USA) & $=0.912$ & ICV (Poland) & $=6.630$ \\
\hline & ISI (Dubai, UAE & $=0.829$ & РИНЦ (Russia & $=0.156$ & PIF (India) & $=1.940$ \\
\hline & GIF (Australia) & $=0.564$ & ESJI (KZ) & $=8.716$ & IBI (India) & $=4.260$ \\
\hline & JIF & $=1.500$ & SJIF (Morocce & $=5.667$ & OAJI (USA) & $=0.350$ \\
\hline
\end{tabular}

\begin{tabular}{|c|c|c|c|c|c|c|c|c|c|c|c|c|c|c|}
\hline 23 & 2 & 10 & 13 & 11 & 9 & 6 & 8 & 12 & 7 & 5 & 1 & 3 & 4 & 0,38 \\
\hline 24 & 12 & 4 & 1 & 2 & 8 & 9 & 3 & 7 & 5 & 10 & 13 & 11 & 6 & 0,70 \\
\hline 25 & 10 & 9 & 1 & 2 & 12 & 3 & 4 & 6 & 5 & 11 & 13 & 7 & 8 & 0,84 \\
\hline 26 & 5 & 6 & 1 & 7 & 11 & 13 & 2 & 10 & 3 & 9 & 12 & 4 & 8 & 0,54 \\
\hline 27 & 11 & 10 & 5 & 4 & 1 & 3 & 9 & 2 & 7 & 12 & 13 & 8 & 6 & 0,58 \\
\hline 28 & 7 & 6 & 5 & 2 & 1 & 8 & 9 & 3 & 4 & 12 & 13 & 11 & 10 & 0,63 \\
\hline 29 & 9 & 10 & 2 & 3 & 6 & 11 & 8 & 7 & 4 & 12 & 13 & 5 & 1 & 0,55 \\
\hline 30 & 8 & 10 & 4 & 5 & 1 & 3 & 9 & 2 & 11 & 12 & 13 & 7 & 6 & 0,57 \\
\hline $\begin{array}{l}\text { Сум } \\
\text { мы } \\
\text { ранг } \\
\text { ов } \\
\end{array}$ & 206 & $\begin{array}{l}246, \\
5\end{array}$ & 91 & 135 & $\begin{array}{l}193, \\
5\end{array}$ & 190 & 164 & 224 & 151 & 287 & 337 & 249 & 256 & \\
\hline $\begin{array}{l}\text { Сум } \\
\text { ма } \\
\text { ранг } \\
\text { ов } \\
\text { без } \\
\text { ерет } \\
\text { иков }\end{array}$ & 46 & 50 & 6 & 14 & 39 & 27 & 16 & 42 & 16 & 42 & 64 & 34 & 49 & \\
\hline $\begin{array}{l}\text { Квад } \\
\text { - } \\
\text { откл. }\end{array}$ & 16 & $\begin{array}{l}1332 \\
, 25\end{array}$ & $\begin{array}{l}1416 \\
1\end{array}$ & 5625 & $\begin{array}{l}272, \\
25\end{array}$ & 400 & 2116 & 196 & 3481 & 5929 & $\begin{array}{l}1612 \\
9\end{array}$ & 1521 & 2116 & \\
\hline $\begin{array}{l}\text { Коэф } \\
\text { конк } \\
\text { орд. }\end{array}$ & & 0,33 & & 0,84 & & & & & & & & & & \\
\hline $\begin{array}{l}\text { Крит } \\
\text { Пирс } \\
\text { она }\end{array}$ & & $\begin{array}{l}117 \\
14\end{array}$ & & 8,37 & & & & & & & & & & \\
\hline
\end{tabular}

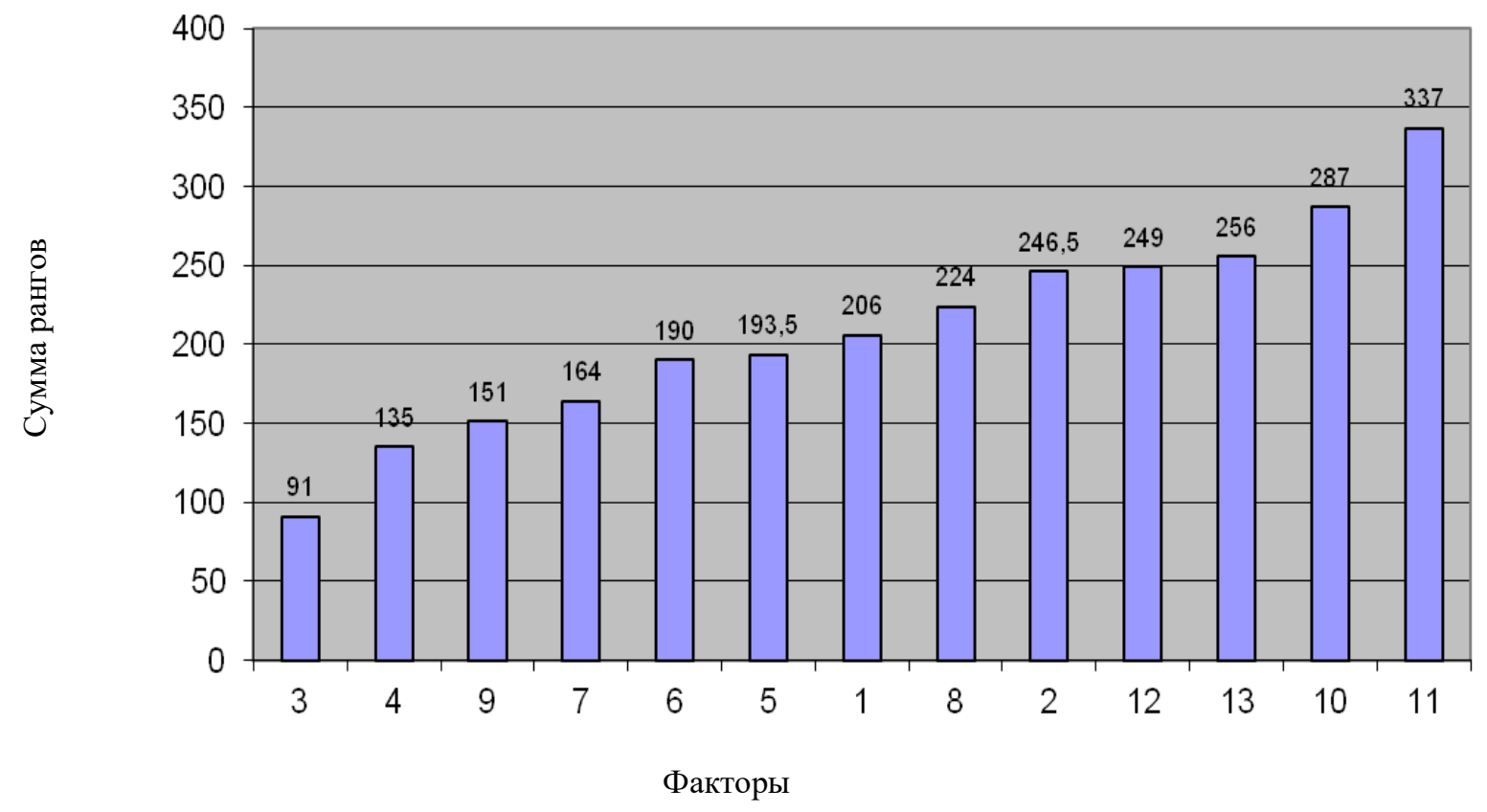

Figure 5 -The results of processing the survey of manufacturers participating in the survey for assessing the competitiveness of and demand for children's shoes 


\begin{tabular}{llllll} 
& ISRA (India) $=\mathbf{3 . 1 1 7}$ & SIS (USA) & $=\mathbf{0 . 9 1 2}$ & ICV (Poland) & $=\mathbf{6 . 6 3 0}$ \\
Impact Factor: & ISI (Dubai, UAE) $=\mathbf{0 . 8 2 9}$ & PUHL (Russia) $=\mathbf{0 . 1 5 6}$ & PIF (India) & $=\mathbf{1 . 9 4 0}$ \\
& GIF (Australia) $=\mathbf{0 . 5 6 4}$ & ESJI (KZ) & $=\mathbf{8 . 7 1 6}$ & IBI (India) & $=\mathbf{4 . 2 6 0}$ \\
& JIF & $\mathbf{1 . 5 0 0}$ & SJIF (Morocco) $=\mathbf{5 . 6 6 7}$ & OAJI (USA) & $\mathbf{0 . 3 5 0}$ \\
\hline
\end{tabular}

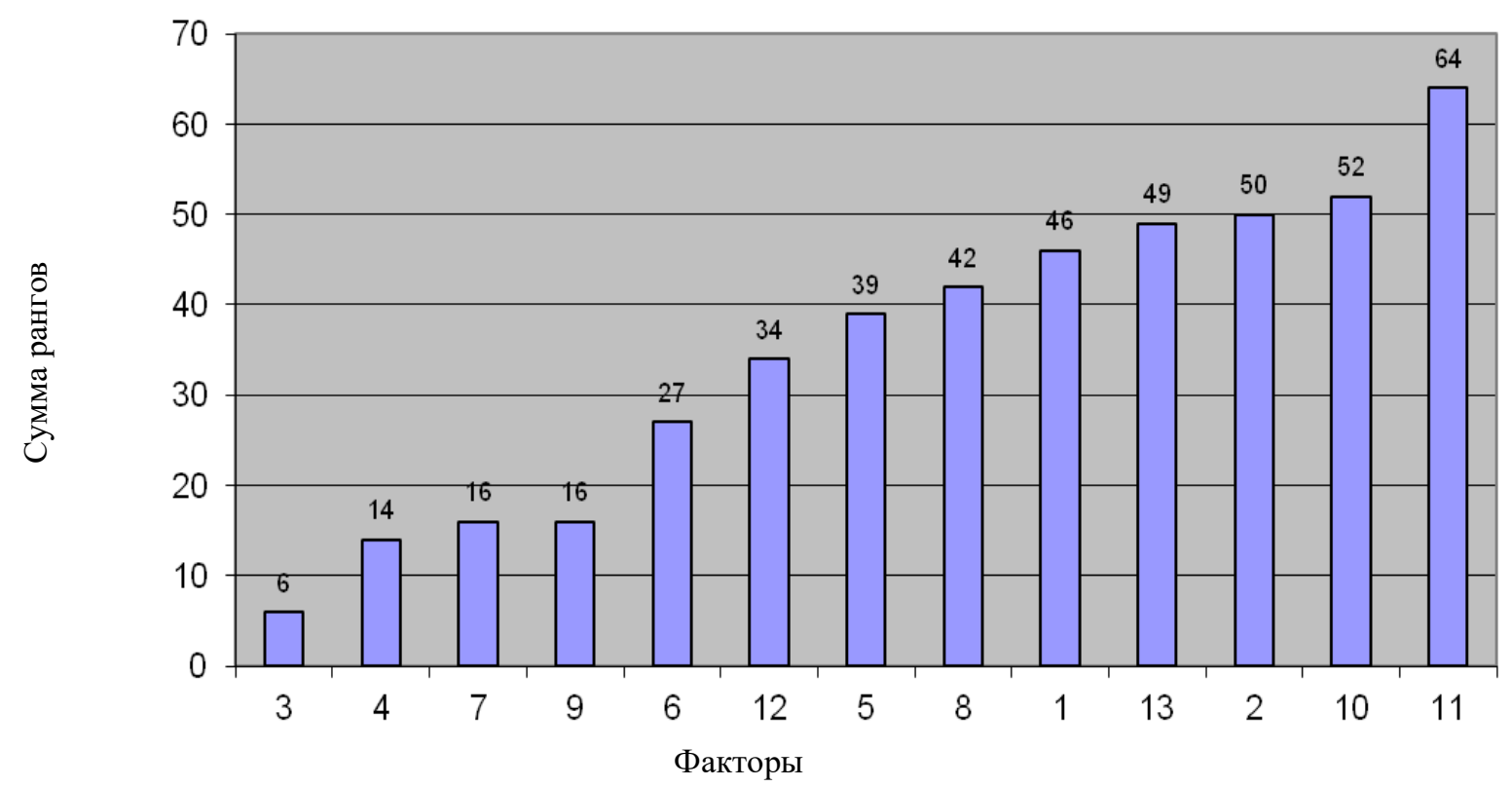

Figure 6 -The results of processing the survey of manufacturers participating in the survey for assessing the competitiveness of and demand for children's shoes without heretics, that is, whose opinion is not consistent with the majority of survey participants

Table 8 - Criteria for assessing the competitiveness of and demand for the eyes of children's shoes parents

\begin{tabular}{|l|l|l|}
\hline number & $\begin{array}{l}\text { The list of factors to evaluate the competitive capacity of enterprises and regions of the } \\
\text { Southern Federal District North Caucasus Federal District in the production of } \\
\text { children's shoes }\end{array}$ & Rank \\
\hline one & Weight & \\
\hline 2 & Colour & \\
\hline 3 & Quality children's shoes & \\
\hline four & $\begin{array}{l}\text { Color fastness applied to the shoe upper material to dry and wet abrasion and exposure } \\
\text { to sweat }\end{array}$ & \\
\hline five & Flexibility & \\
\hline 6 & Durability fastening shoe bottom & \\
\hline 7 & Price & \\
\hline eight & comfort & \\
\hline 9 & The deformation of the toe cap and backdrop & \\
\hline ten & repairability & \\
\hline eleven & The warranty period for children's shoes & \\
\hline
\end{tabular}

Table 9 - Results of processing the survey of parents who participated in the survey for assessing the competitiveness of and demand for children's shoes

\begin{tabular}{|l|l|l|l|l|l|l|l|l|l|l|l|l|}
\hline Фактор & \multirow{2}{*}{ Х1 } & $\mathbf{X 2}$ & $\mathbf{X 3}$ & $\mathbf{X 4}$ & $\mathbf{X 5}$ & $\mathbf{X 6}$ & $\mathbf{X 7}$ & $\mathbf{X 8}$ & $\mathbf{X 9}$ & $\mathbf{X 1 0}$ & $\mathbf{X 1 1}$ & $\mathbf{K \kappa}$ \\
\hline Эксперт & & & & & & & & & & & & \\
\hline $\mathbf{2}$ & 4 & 11 & 2 & 3 & 7 & 5 & 6 & 1 & 8 & 10 & 9 & 0,81 \\
\hline $\mathbf{3}$ & 3 & 4 & 1 & 7 & 8 & 6 & 5 & 2 & 11 & 10 & 9 & 0,86 \\
\hline $\mathbf{4}$ & 2 & 4 & 1 & 5 & 6 & 8 & 7 & 2 & 10 & 9 & 11 & 0,86 \\
\hline $\mathbf{5}$ & 4 & 6 & 1 & 7 & 4 & 11 & 5 & 3 & 9 & 10 & 8 & 0,88 \\
\hline
\end{tabular}




\begin{tabular}{|c|c|c|c|c|c|c|}
\hline \multirow{4}{*}{ Impact Factor: } & ISRA (India) & $=3.117$ & SIS (USA) & $=0.912$ & ICV (Poland) & $=6.630$ \\
\hline & ISI (Dubai, UAE & $=0.829$ & РИНЦ (Russia) & $=0.156$ & PIF (India) & $=1.940$ \\
\hline & GIF (Australia) & $=0.564$ & ESJI (KZ) & $=8.716$ & IBI (India) & $=4.260$ \\
\hline & JIF & $=1.500$ & SJIF (Morocco) & $=5.667$ & OAJI (USA) & $=0.350$ \\
\hline
\end{tabular}

\begin{tabular}{|l|l|l|l|l|l|l|l|l|l|l|l|l|} 
6 & 4 & 8 & 1 & 7 & 6 & 5 & 3 & 2 & 11 & 10 & 9 & 0,90 \\
\hline $\mathbf{7}$ & 3 & 5 & 1 & 8 & 6 & 9 & 2 & 4 & 11 & 7 & 10 & 0,92 \\
\hline $\mathbf{8}$ & 2 & 3 & 4 & 10 & 5 & 8 & 9 & 1 & 11 & 6 & 7 & 0,80 \\
\hline $\mathbf{9}$ & 3 & 4 & 1 & 7 & 2 & 6 & 5 & 10 & 11 & 8 & 9 & 0,74 \\
\hline $\mathbf{1 0}$ & 2 & 8 & 1 & 7 & 3 & 5 & 6 & 4 & 10 & 9 & 11 & 0,84 \\
\hline $\mathbf{1 1}$ & 3 & 7 & 1 & 6 & 5 & 8 & 4 & 2 & 10 & 9 & 11 & 0,92 \\
\hline $\mathbf{1 2}$ & 2 & 6 & 3 & 5 & 7 & 9 & 4 & 1 & 11 & 8 & 10 & 0,84 \\
\hline $\mathbf{1 3}$ & 4 & 6 & 3 & 5 & 7 & 10 & 1 & 2 & 11 & 8 & 9 & 0,94 \\
\hline $\mathbf{1 4}$ & 4 & 7 & 3 & 6 & 5 & 10 & 1 & 2 & 11 & 8 & 9 & 0,94 \\
\hline $\mathbf{1 5}$ & 3 & 8 & 4 & 6 & 5 & 7 & 1 & 2 & 11 & 10 & 9 & 0,94 \\
\hline $\mathbf{1 6}$ & 2 & 5 & 4 & 6 & 7 & 10 & 3 & 1 & 11 & 9 & 8 & 0,93 \\
\hline $\mathbf{1 7}$ & 5 & 9 & 2 & 8 & 6 & 4 & 1 & 3 & 10 & 11 & 7 & 0,83 \\
\hline $\mathbf{1 8}$ & 3 & 7 & 2 & 8 & 4 & 9 & 6 & 1 & 10 & 11 & 5 & 0,85 \\
\hline $\mathbf{1 9}$ & 6 & 5 & 1 & 8 & 4 & 7 & 3 & 2 & 9 & 10 & 11 & 0,87 \\
\hline $\mathbf{2 0}$ & 3 & 7 & 4 & 6 & 5 & 8 & 1 & 2 & 9 & 11 & 10 & 0,94 \\
\hline $\mathbf{2 1}$ & 3 & 7 & 4 & 6 & 5 & 8 & 2 & 1 & 9 & 10 & 11 & 0,94 \\
\hline $\mathbf{2 2}$ & 1 & 3 & 5 & 4 & 8 & 7 & 9 & 10 & 2 & 11 & 6 & 0,55 \\
\hline $\mathbf{2 3}$ & 9 & 10 & 1 & 8 & 4 & 3 & 5 & 2 & 11 & 6 & 7 & 0,72 \\
\hline $\mathbf{2 4}$ & 4 & 2 & 3 & 1 & 6 & 7 & 5 & 8 & 11 & 10 & 9 & 0,77 \\
\hline $\mathbf{2 5}$ & 5 & 11 & 1 & 4 & 2 & 3 & 10 & 6 & 7 & 9 & 8 & 0,64 \\
\hline $\mathbf{2 6}$ & 1 & 7 & 6 & 8 & 5 & 9 & 10 & 2 & 11 & 3 & 4 & 0,61 \\
\hline $\mathbf{2 7}$ & 4 & 9 & 6 & 7 & 5 & 3 & 10 & 2 & 1 & 11 & 8 & 0,59 \\
\hline $\mathbf{2 8}$ & 2 & 1 & 3 & 8 & 10 & 9 & 4 & 7 & 6 & 11 & 5 & 0,70 \\
\hline $\mathbf{2 9}$ & 4 & 7 & 1 & 2 & 8 & 3 & 5 & 10 & 6 & 9 & 11 & 0,67 \\
\hline $\begin{array}{l}\text { Суммы } \\
\text { рангов }\end{array}$ & 98 & 185 & 71 & 178 & 162 & 206 & 136 & 97 & 269 & 265 & 247 & \\
\hline $\begin{array}{l}\text { Сумма } \\
\text { рангов } \\
\text { еретиков }\end{array}$ & 17 & 35 & 18 & 29 & 27 & 43 & 6 & 9 & 51 & 47 & 48 & \\
\hline $\begin{array}{l}\text { Коэф. } \\
\text { конкорд. }\end{array}$ & & 0,52 & & 0,94 & & & & & & & & \\
\hline $\begin{array}{l}\text { Крит. } \\
\text { Пирсона }\end{array}$ & & 149 & & 8,1 & & & & & & & & \\
\hline
\end{tabular}




\begin{tabular}{|c|c|c|c|c|c|c|}
\hline \multirow{4}{*}{ Impact Factor: } & ISRA (India) & $=3.117$ & SIS (USA) & $=0.912$ & ICV (Poland) & $=6.630$ \\
\hline & ISI (Dubai, UAE & $=0.829$ & РИНЦ (Russia & $=0.156$ & PIF (India) & $=1.940$ \\
\hline & GIF (Australia) & $=0.564$ & ESJI (KZ) & $=8.716$ & IBI (India) & $=4.260$ \\
\hline & JIF & $=1.500$ & SJIF (Morocco & $=5.667$ & OAJI (USA) & $=0.350$ \\
\hline
\end{tabular}

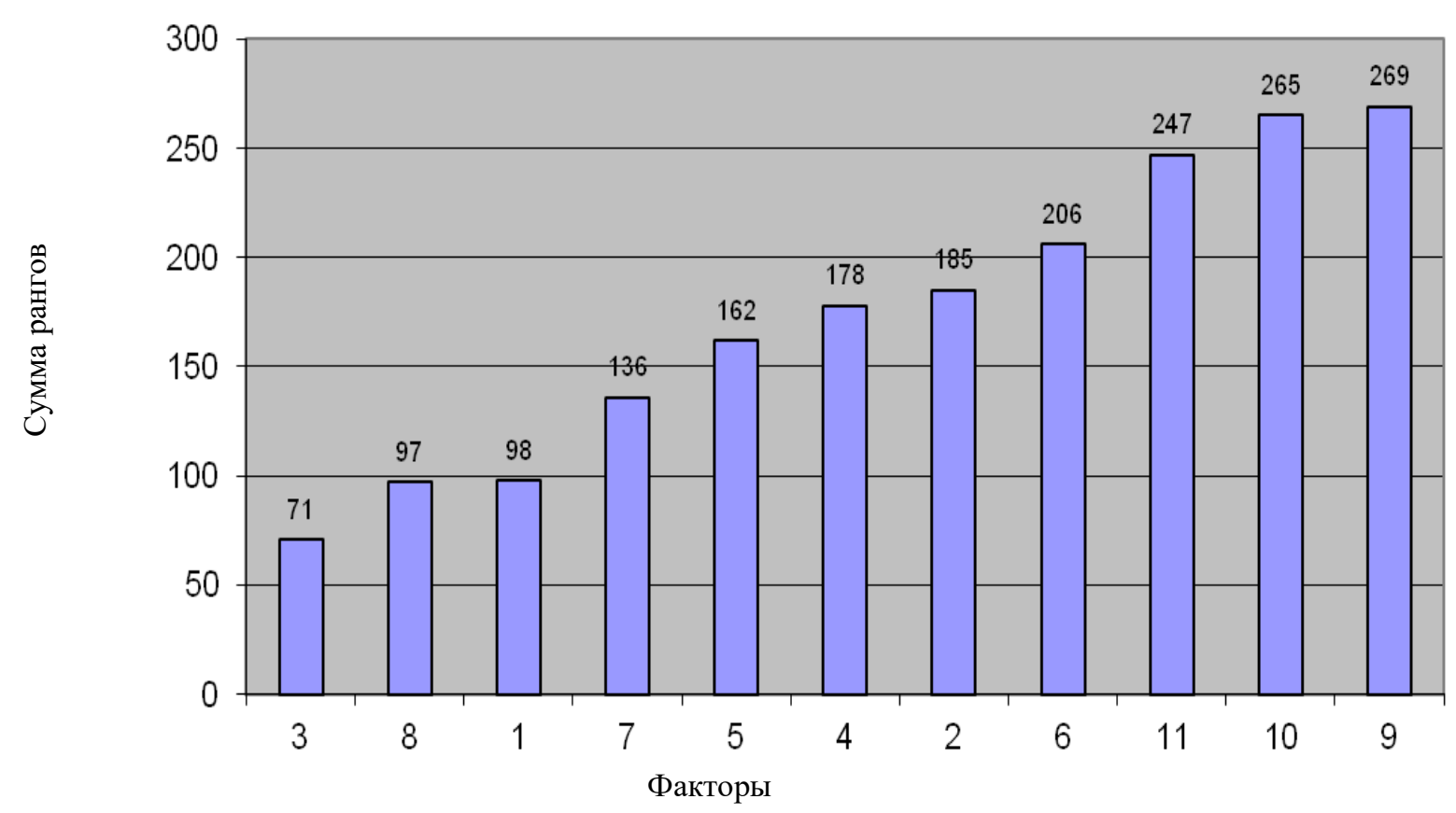

Figure 7 -The results of processing the survey of parents who participated in the survey for assessing the competitiveness of and demand for children's shoes

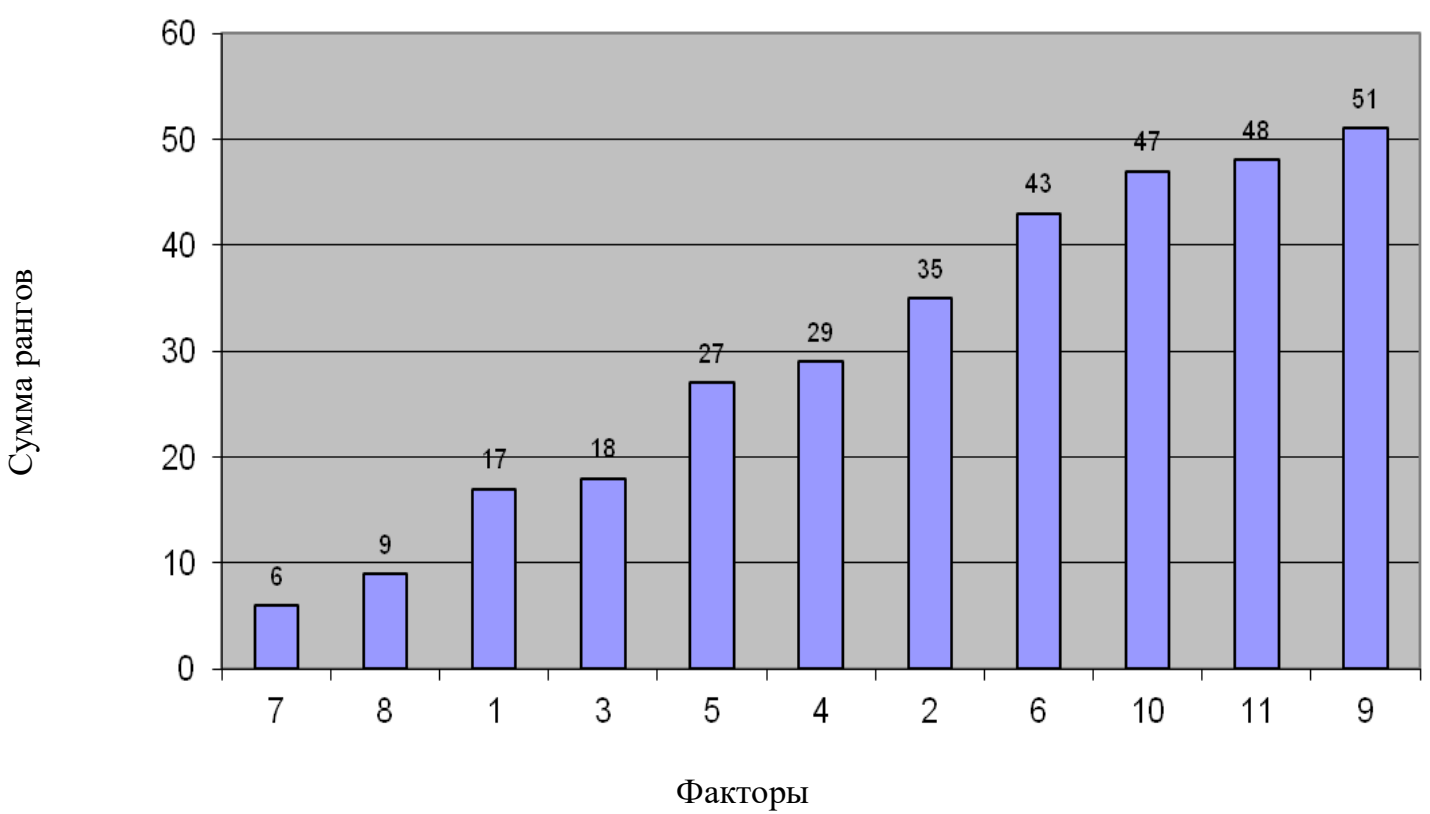

Figure 8 -The results of processing the survey of manufacturers participating in the survey for assessing the competitiveness of and demand for children's shoes without heretics, that is, whose opinion is not consistent with the majority of survey participants

Table 10. Summary of characteristics of respondents the survey results - the children, their parents, consumers and manufacturers to assess the competitive potential of the shoe enterprises SFD and North Caucasus Federal District regions

\begin{tabular}{|l|l|l|l|}
\hline children Poll Results & Parents Poll Results & customer survey results & manufacturers Poll Results \\
\hline $\begin{array}{l}2-\text { The quality of } \\
\text { children's shoes }\end{array}$ & $\begin{array}{l}3 \text { - The quality of } \\
\text { children's shoes }\end{array}$ & $\begin{array}{l}3-\text { The quality of children's } \\
\text { shoes }\end{array}$ & $\begin{array}{l}\text { 3 - The quality of children's } \\
\text { shoes }\end{array}$ \\
\hline
\end{tabular}




\begin{tabular}{|c|c|c|c|c|c|c|}
\hline \multirow{4}{*}{ Impact Factor: } & ISRA (India) & $=3.117$ & SIS (USA) & $=0.912$ & ICV (Poland) & $=6.630$ \\
\hline & ISI (Dubai, UAE & $=0.829$ & РИНЦ (Russia & $=0.156$ & PIF (India) & $=1.940$ \\
\hline & GIF (Australia) & $=0.564$ & ESJI (KZ) & $=8.716$ & IBI (India) & $=4.260$ \\
\hline & JIF & $=1.500$ & SJIF (Morocce & $=5.667$ & OAJI (USA) & $=0.350$ \\
\hline
\end{tabular}

\begin{tabular}{|c|c|c|c|}
\hline 1 - Form forefoot & 8 - The comfort & 9 - The comfort & $\begin{array}{l}4 \text { - Functionality children's } \\
\text { shoes }\end{array}$ \\
\hline 11 - Weight & 1 - Weight & $\begin{array}{l}6-\text { Compliance with the } \\
\text { fashion direction }\end{array}$ & 9 - The comfort \\
\hline 5 - Comfort & 7 - Price & 7 - Price & 7 - Price \\
\hline $\begin{array}{l}13 \text { - Materials for the } \\
\text { bottom of shoes }\end{array}$ & 5 - Flexibility & $\begin{array}{l}4 \text { - Functionality children's } \\
\text { shoes }\end{array}$ & $\begin{array}{l}6 \text { - Compliance with the } \\
\text { fashion direction }\end{array}$ \\
\hline $\begin{array}{l}22 \text { - Compliance with } \\
\text { the fashion direction }\end{array}$ & $\begin{array}{l}4 \text { - Stability of color } \\
\text { applied to the shoe } \\
\text { upper material to dry } \\
\text { and wet abrasion and } \\
\text { exposure to sweat }\end{array}$ & 1 - Weight & $\begin{array}{l}5-\text { Characterization of } \\
\text { materials for shoe uppers }\end{array}$ \\
\hline $\begin{array}{l}4-\text { The price of } \\
\text { children's shoes }\end{array}$ & 2 - Color & $\begin{array}{l}5-\text { Characterization of } \\
\text { materials for shoe uppers }\end{array}$ & 1 - Weight \\
\hline $\begin{array}{l}21 \text { - The diversity of the } \\
\text { range shoes for children } \\
\text { in shops and malls }\end{array}$ & $\begin{array}{lr}6 \quad- & \text { Durability } \\
\text { fastening } & \text { shoe } \\
\text { bottom } & \\
\end{array}$ & $\begin{array}{l}8-\text { Characterization of } \\
\text { materials for the bottom of } \\
\text { shoes }\end{array}$ & $\begin{array}{l}8-\text { Characterization of } \\
\text { materials for the bottom of } \\
\text { shoes }\end{array}$ \\
\hline $\begin{array}{l}6 \text { - The level of service } \\
\text { of parents and children } \\
\text { in shops and malls }\end{array}$ & $\begin{array}{l}11 \text { - The warranty } \\
\text { period for children's } \\
\text { shoes }\end{array}$ & 2 - Color & 2 - Color \\
\hline 7 - Color & 10 - Maintainability & $\begin{array}{l}15 \text { - What type of children's } \\
\text { shoes are preferred: autumn }\end{array}$ & 12 - Maintainability \\
\hline $\begin{array}{l}9 \text { - The height of the heel } \\
\text { portion elation -up to } 40 \\
\text { mm }\end{array}$ & $\begin{array}{l}9 \text { - The deformation } \\
\text { of the toe cap and } \\
\text { backdrop }\end{array}$ & $\begin{array}{l}10 \text { - Height elation heel of } \\
\text { the shoe }-40 \mathrm{~mm}\end{array}$ & $\begin{array}{l}13 \text { - The warranty period for } \\
\text { children's shoes }\end{array}$ \\
\hline $\begin{array}{l}15 \text { - Place of sale shoes } \\
\text { for children - shop } \\
\text { interior, or shopping } \\
\text { center }\end{array}$ & & $\begin{array}{l}14 \text { - What type of children's } \\
\text { shoes are preferred: winter }\end{array}$ & $\begin{array}{l}10 \text { - Height elation heel of } \\
\text { the shoe }-40 \mathrm{~mm}\end{array}$ \\
\hline $\begin{array}{l}8 \text { - The warranty period } \\
\text { for children's shoes }\end{array}$ & & $\begin{array}{l}11 \text { - The height of the heel of } \\
\text { the shoe elation -svyshe } 40 \\
\text { mm }\end{array}$ & $\begin{array}{l}11 \text { - The height of the heel of } \\
\text { the shoe elation -svyshe } 40 \\
\mathrm{~mm}\end{array}$ \\
\hline $\begin{array}{l}16-\text { What type of } \\
\text { children's shoes are } \\
\text { preferred: Winter }\end{array}$ & & 12 - Maintainability & \\
\hline $\begin{array}{l}18-\text { What type of } \\
\text { children's shoes are } \\
\text { preferred: spring }\end{array}$ & & $\begin{array}{l}18 \text { - Durability fastening } \\
\text { shoe bottom }\end{array}$ & \\
\hline $\begin{array}{l}12-\text { Maintainability } \\
\text { children's shoes its } \\
\text { expediency }\end{array}$ & & $\begin{array}{l}16 \text { - What type of children's } \\
\text { shoes are preferred: spring }\end{array}$ & \\
\hline $\begin{array}{l}3 \text { - Flexibility children's } \\
\text { shoes }\end{array}$ & & $\begin{array}{l}13 \text { - The warranty period for } \\
\text { children's shoes }\end{array}$ & \\
\hline $\begin{array}{l}10-\text { The height of the } \\
\text { heel of the shoe elation - } \\
\text { svyshe } 40 \mathrm{~mm}\end{array}$ & & $\begin{array}{l}17 \text { - What type of children's } \\
\text { shoes are preferred: Summer }\end{array}$ & \\
\hline $\begin{array}{l}17-\text { What type of } \\
\text { children's shoes are } \\
\text { preferred: autumn }\end{array}$ & & & \\
\hline \multicolumn{4}{|l|}{$\begin{array}{l}20 \text { - Durability fastening } \\
\text { shoe bottom }\end{array}$} \\
\hline \multicolumn{4}{|l|}{$\begin{array}{l}14 \text { - Materials for shoe } \\
\text { uppers }\end{array}$} \\
\hline \multicolumn{4}{|l|}{$\begin{array}{l}19-\text { What type of } \\
\text { children's shoes are } \\
\text { preferred: Summer }\end{array}$} \\
\hline $0,16<\mathrm{W}<0,69$ & $0,52<\mathrm{W}<0,94$ & $0,47<\mathrm{W}<0,91$ & $0,33<\mathrm{W}<0,84$ \\
\hline
\end{tabular}




\begin{tabular}{|c|c|c|c|c|c|c|}
\hline \multirow{4}{*}{ Impact Factor: } & ISRA (India) & $=3.117$ & SIS (USA) & $=0.912$ & ICV (Poland) & $=6.630$ \\
\hline & ISI (Dubai, UAE & $=0.829$ & РИНЦ (Russia & $=0.156$ & PIF (India) & $=1.940$ \\
\hline & GIF (Australia) & $=0.564$ & ESJI (KZ) & $=8.716$ & IBI (India) & $=4.260$ \\
\hline & JIF & $=1.500$ & SJIF (Morocce & $=5.667$ & OAJI (USA) & $=0.350$ \\
\hline
\end{tabular}

Table 11 Summary characteristics of survey respondents outcomes - children, parents, consumers and manufacturers to assess the competitive potential of the shoe enterprises SFD and North Caucasus Federal District regions, but without heretics, whose opinion does not coincide with the majority of respondents to the survey

\begin{tabular}{|c|c|c|c|}
\hline children Poll Results & Parents Poll Results & customer survey results & manufacturers Poll Results \\
\hline $\begin{array}{l}2-\text { The quality of } \\
\text { children's shoes }\end{array}$ & 7 - Price & $\begin{array}{l}6 \text { - Compliance with the fashion } \\
\text { direction }\end{array}$ & $\begin{array}{l}3 \text { - The quality of children's } \\
\text { shoes }\end{array}$ \\
\hline 5 - Comfort & 8 - The comfort & 9 - The comfort & $\begin{array}{l}4 \text { - Functionality children's } \\
\text { shoes }\end{array}$ \\
\hline 11 - Weight & 1 - Weight & 7 - Price & 7 - Price \\
\hline $\begin{array}{l}22 \text { - Compliance with the } \\
\text { fashion direction }\end{array}$ & $\begin{array}{l}3 \text { - The quality of } \\
\text { children's shoes }\end{array}$ & $\begin{array}{l}3 \text { - The quality of children's } \\
\text { shoes }\end{array}$ & 9 - The comfort \\
\hline $\begin{array}{l}16-\text { What type of } \\
\text { children's shoes are } \\
\text { preferred: Winter }\end{array}$ & 5 - Flexibility & $\begin{array}{l}15 \text { - What type of children's } \\
\text { shoes are preferred: autumn }\end{array}$ & $\begin{array}{l}6 \text { - Compliance with the } \\
\text { fashion direction }\end{array}$ \\
\hline $\begin{array}{l}6 \text { - The level of service of } \\
\text { parents and children in } \\
\text { shops and malls }\end{array}$ & $\begin{array}{l}4 \text { - Stability of color } \\
\text { applied to the shoe } \\
\text { upper material to dry } \\
\text { and wet abrasion and } \\
\text { exposure to sweat }\end{array}$ & 1 - Weight & 12 - Maintainability \\
\hline $\begin{array}{l}21 \text { - The diversity of the } \\
\text { range shoes for children } \\
\text { in shops and malls }\end{array}$ & 2 - Color & $\begin{array}{l}14 \text { - What type of children's } \\
\text { shoes are preferred: winter }\end{array}$ & $\begin{array}{l}5-\text { Characterization of } \\
\text { materials for shoe uppers }\end{array}$ \\
\hline $\begin{array}{l}4 \text { - The price of children's } \\
\text { shoes }\end{array}$ & 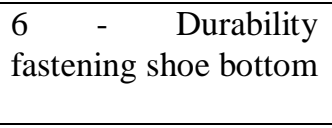 & $\begin{array}{l}4-\text { Functionality children's } \\
\text { shoes }\end{array}$ & $\begin{array}{l}8-\text { Characterization of } \\
\text { materials for the bottom of } \\
\text { shoes }\end{array}$ \\
\hline 7 - Color & 10 - Maintainability & $\begin{array}{l}5 \text { - Characterization of materials } \\
\text { for shoe uppers }\end{array}$ & 1 - Weight \\
\hline 1 - Form forefoot & $\begin{array}{l}11 \text { - The warranty } \\
\text { period for children's } \\
\text { shoes }\end{array}$ & $\begin{array}{l}11 \text { - The height of the heel of the } \\
\text { shoe elation -svyshe } 40 \mathrm{~mm}\end{array}$ & $\begin{array}{l}13 \text { - The warranty period for } \\
\text { children's shoes }\end{array}$ \\
\hline $\begin{array}{lr}12 \quad- & \text { Maintainability } \\
\text { children's } & \text { shoes its } \\
\text { expediency } & \end{array}$ & $\begin{array}{l}\text { 9- The deformation of } \\
\text { the toe cap and } \\
\text { backdrop }\end{array}$ & 2 - Color & 2 - Color \\
\hline $\begin{array}{l}8 \text { - The warranty period } \\
\text { for children's shoes }\end{array}$ & & $\begin{array}{l}8 \text { - Characterization of materials } \\
\text { for the bottom of shoes }\end{array}$ & $\begin{array}{l}10 \text { - Height elation heel of } \\
\text { the shoe }-40 \mathrm{~mm}\end{array}$ \\
\hline $\begin{array}{l}13 \text { - Materials for the } \\
\text { bottom of shoes }\end{array}$ & & $\begin{array}{l}10 \text { - Height elation heel of the } \\
\text { shoe - } 40 \mathrm{~mm}\end{array}$ & $\begin{array}{l}11 \text { - The height of the heel of } \\
\text { the shoe elation -svyshe } 40 \\
\mathrm{~mm}\end{array}$ \\
\hline $\begin{array}{l}15 \text { - Place of sale shoes } \\
\text { for children }- \text { shop } \\
\text { interior, or shopping } \\
\text { center }\end{array}$ & & $\begin{array}{l}16 \text { - What type of children's } \\
\text { shoes are preferred: spring }\end{array}$ & \\
\hline $\begin{array}{l}18-\text { What type of } \\
\text { children's shoes are } \\
\text { preferred: spring }\end{array}$ & & $\begin{array}{l}17 \text { - What type of children's } \\
\text { shoes are preferred: Summer }\end{array}$ & \\
\hline $\begin{array}{l}3 \text { - Flexibility children's } \\
\text { shoes }\end{array}$ & & $\begin{array}{l}18 \text { - Durability fastening shoe } \\
\text { bottom }\end{array}$ & \\
\hline $\begin{array}{l}19-\text { What type of } \\
\text { children's shoes are } \\
\text { preferred: Summer }\end{array}$ & & 12 - Maintainability & \\
\hline $\begin{array}{l}14 \text { - Materials for shoe } \\
\text { uppers }\end{array}$ & & $\begin{array}{l}13 \text { - The warranty period for } \\
\text { children's shoes }\end{array}$ & \\
\hline $\begin{array}{l}9 \text { - The height of the heel } \\
\text { portion elation -up to } 40 \\
\text { mm }\end{array}$ & & & \\
\hline
\end{tabular}




\begin{tabular}{|c|c|c|c|c|c|c|}
\hline \multirow{4}{*}{ Impact Factor: } & ISRA (India) & $=3.117$ & SIS (USA) & $=0.912$ & ICV (Poland) & $=6.630$ \\
\hline & ISI (Dubai, UAI & $=0.829$ & РИНЦ (Russia & $=0.156$ & PIF (India) & $=1.940$ \\
\hline & GIF (Australia) & $=0.564$ & ESJI (KZ) & $=8.716$ & IBI (India) & $=4.260$ \\
\hline & JIF & $=1.500$ & SJIF (Morocce & $=5.667$ & OAJI (USA) & $=0.350$ \\
\hline
\end{tabular}

\begin{tabular}{|l|l|l|l|}
\hline $\begin{array}{l}10-\text { The height of the heel } \\
\text { of the shoe elation - } \\
\text { svyshe } 40 \mathrm{~mm}\end{array}$ & & \\
\hline $\begin{array}{l}20-\text { Durability fastening } \\
\text { shoe bottom }\end{array}$ & & & \\
\hline $\begin{array}{l}17-\text { What type of } \\
\text { children's shoes are } \\
\text { preferred: autumn }\end{array}$ & & & \\
\hline $0,16<\mathrm{W}<0,69$ & $0,52<\mathrm{W}<0,94$ & $0,47<\mathrm{W}<0,91$ & $0,33<\mathrm{W}<0,84$ \\
\hline
\end{tabular}

In addition, the tables 3-6 shows that if men's shoes sold below $48 \%$, women - $44 \%$ and $83 \%$ of children, the company suffers losses, making it necessary to reduce the volume of production, delay the payment of salaries and working etc .If you encounter this situation it is necessary to attract borrowed funds to cover the costs and organization of the subsequent output that is currently associated with certain difficulties: significantly increased interest for the loan $(20 \%)$, reduced the terms of repayment, etc., leading to even more. an increase in production costs.

The market conditions of managing an effective management system requires a rational organization of the sales activity, which largely determines the enterprise level of use of means of production, labor productivity, reduce production costs, increase profits and profitability. This is due to the fact that marketing activities - this is not only the sale of finished shoes, but also the orientation of production to meet the demand of buyers solvency and active work in the market for the maintenance and development of the demand for the company's products, and the organization of effective distribution channels and promotion goods'. In conditions rapidly changing market environment, business results, including shoe, depend largely on the effective results of production, sales,

Thus, the shoe enterprises in the development of assortment policy should focus both on the outside (price and consumer niche, competing enterprises, market conjecture, etc.) As well as internal factors such as sales volume, profitability, covering the basic costs and others. However, it is impossible to consider and anticipate every situation that may arise in the implementation of the shoe, ie some models of shoes at some point are not in demand. In this case, it should show a different, usually not publicized marketing side: if the shoe, even without considering the demands of the market, has already been made, then it is required to implement. For this purpose, in order to respond to lower prices of competitors, it is necessary to cut too large stocks, to get rid of damaged, defective shoes eliminate residues

In addition to the use of discounts, the company can go to the proactive decrease in prices at underload of production capacity, reducing the market share under the pressure of competition from rival companies, etc. In this case, the company takes care of its costs, developing measures to reduce them by improving equipment and technology, the introduction of new types of materials, continuous improvement of product quality. And all this requires that companies large financial costs, but, nevertheless, increases the competitiveness of certain types of leather products and businesses as a whole. In addition, the greater the number of manufactured footwear products, the more reduced the cost of production, which leads to lower prices, and most importantly - create such conditions functioning of the market,

Assortment policy is to develop the implementation of decisions regarding nomenclature (names) of products, variety of assortment of names, the need to expand the range of manufactured.

Analysis of the results of the survey respondents on the criteria for assessing the competitiveness of and demand for children's shoes with the participation of children, their parents, buyers and manufacturers have confirmed the expected result, namely, the fact that the competence of the participants in the survey are quite different to each other and do not allow to take one only right decision about themselves criteria for evaluation of competitiveness and demand for all types of shoes assortment.

Designed by the authors of the software for the distribution of all the participants in the survey on the extent of their competence on the mentioned process using the concordance coefficient has confirmed its high efficiency for all participants in the survey.

\section{Conclusion.}

Less expertise have natural children, because they have in completing the questionnaire in the first place, such criteria were defined as the mass of the comfort variety of assortment of shoes in a store, service levels, and not those who warn of the child and the parents of the possible formation of their child pathological foot abnormalities. The results of the survey of parents do not have a high compactness of the criteria for assessing the competitiveness of and demand for children's shoes, but they are united by the desire to see in-store quality footwear, in which they put the following understanding: comfort, weight, price and warranty period, although rapidly growing baby feet, this factor is less important. But maybe this is the voice of the parents in a family where three or more children with no significant difference in age. Surprised by the results of a survey of buyers who 


\begin{tabular}{|c|c|c|c|c|c|c|}
\hline \multirow{4}{*}{ Impact Factor: } & ISRA (India) & $=3.117$ & SIS (USA) & $=0.912$ & ICV (Poland) & $=6.630$ \\
\hline & ISI (Dubai, UAE & $=0.829$ & РИНЦ (Russia & $=0.156$ & PIF (India) & $=1.940$ \\
\hline & GIF (Australia) & $=0.564$ & ESJI (KZ) & $=8.716$ & IBI (India) & $=4.260$ \\
\hline & JIF & $=1.500$ & SJIF (Morocce & $=5.667$ & OAJI (USA) & $=0.350$ \\
\hline
\end{tabular}

consciously choose to shop with children's footwear, and the desire to buy a shoe, which is necessary for their child, it is possible to speak of a conscious choice. Confirmation of our assumptions is the fact that consumers, both men and women were unanimous in saying that the children's shoes should be comfortable, easy and affordable. But on the other hand it confirmed the fact that having a lack of competence and consistency in the evaluation criteria of competitiveness and demand for children's shoes, though they assessed the available in-store product range of footwear exclusively with consumer products. And almost no attention to the criteria that would protect their children from the stack formation abnormalities. Sadly, doctors, Orthopedics in children's institutions is not enough pay attention to advocacy among parents, causing them to more informed decision about buying shoes to your child, preferring a shoe that all and only all criteria guarantees a child, his warning the foot, from the formation of pathological deviations. Were only competent answers to the questionnaire on the criteria for assessing the competitiveness of and demand for children's footwear manufacturing representatives. Their criterion - quality children's shoes, children's shoes functionality, comfort, weight, material properties for the top and bottom of footwear, confirms their understanding of the importance of compliance with state standards and requirements of the technical regulations governing the conditions of execution of which ensures children are not only comfortable conditions of the foot, but also protects it from the formation of pathological abnormalities. The good news is the fact that their competence has a high level of consistency with other experts, as evidenced by the value of the $\mathrm{W}$ concordance coefficient, close to unity. That is, parents have every reason to get shoes made from the likes of knowing that their children would stop nothing threatening. Range of children's shoes presented at Fig.9-22.
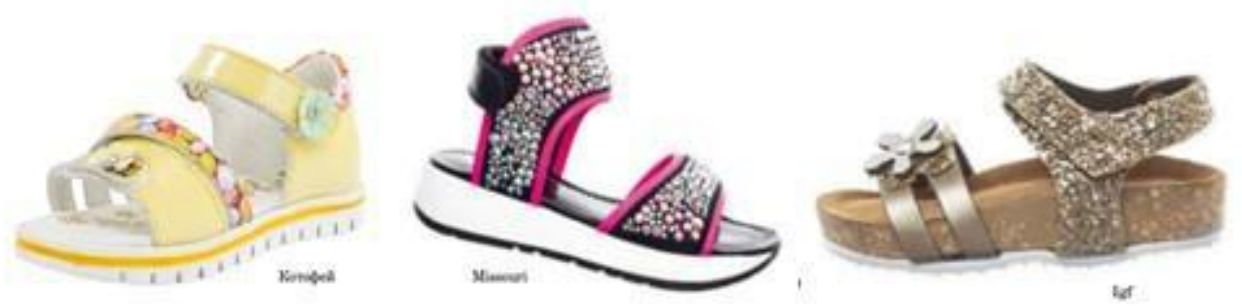

Figure 9 -Populyarnye types and designs of this year sandals
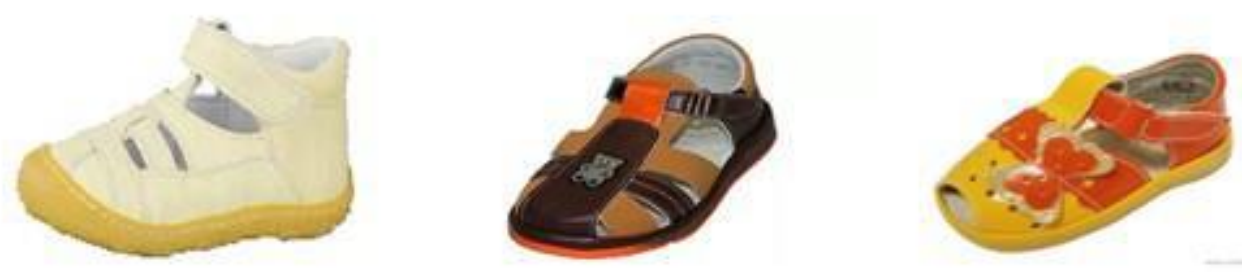

Figure 10 - Popular types and designs of this year anklets
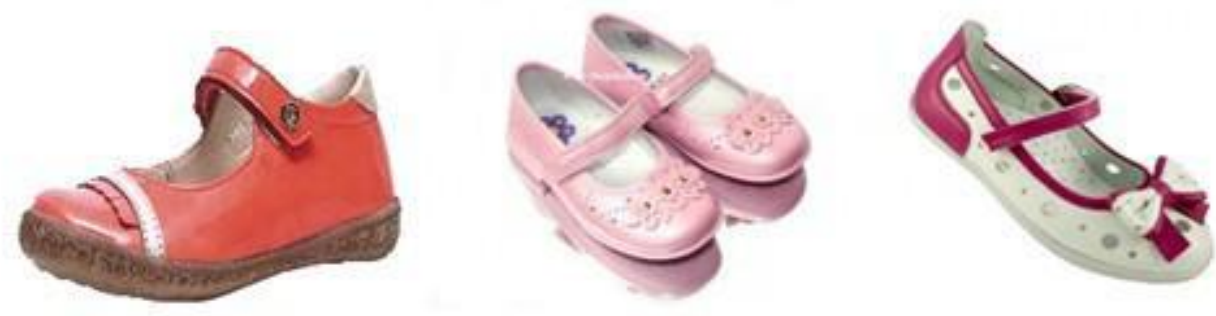

Figure 11 - Popular types and designs of shoes this year, 


\begin{tabular}{|c|c|c|c|c|c|c|}
\hline \multirow{4}{*}{ Impact Factor: } & ISRA (India) & $=3.117$ & SIS (USA) & $=0.912$ & ICV (Poland) & $=6.630$ \\
\hline & ISI (Dubai, UAE & $=0.829$ & РИНЦ (Russia) & $=0.156$ & PIF (India) & $=1.940$ \\
\hline & GIF (Australia) & $=0.564$ & ESJI (KZ) & $=8.716$ & IBI (India) & $=4.260$ \\
\hline & JIF & $=1.500$ & SJIF (Morocco) & $=5.667$ & OAJI (USA) & $=0.350$ \\
\hline
\end{tabular}
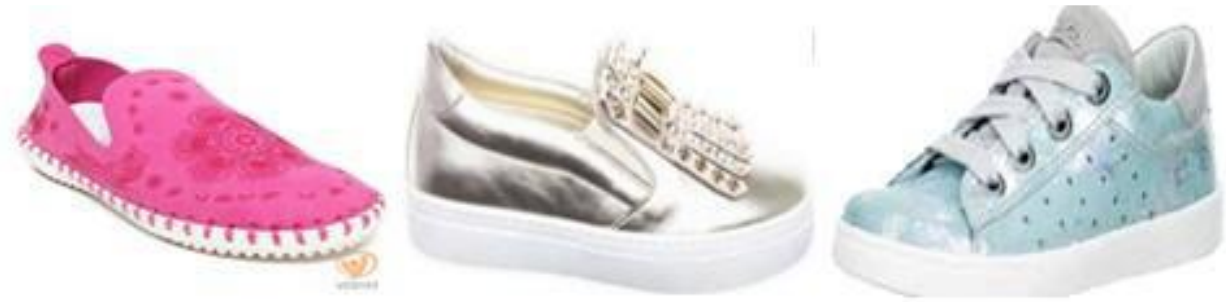

Figure 12 - Popular types and designs of this year sleepers.
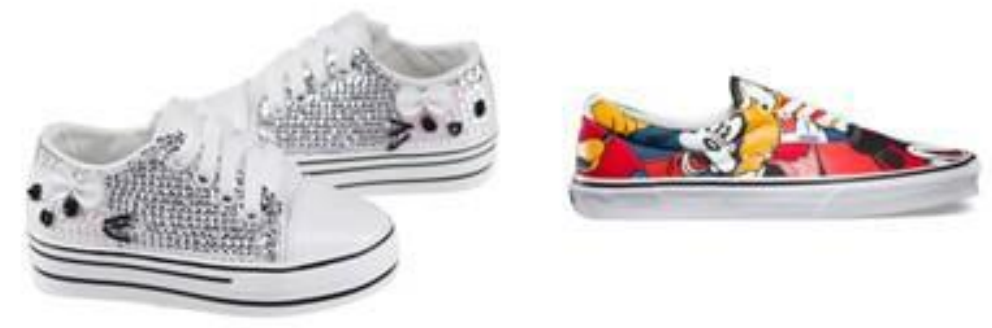

Figure 13 - Popular types and designs of sneakers this year.
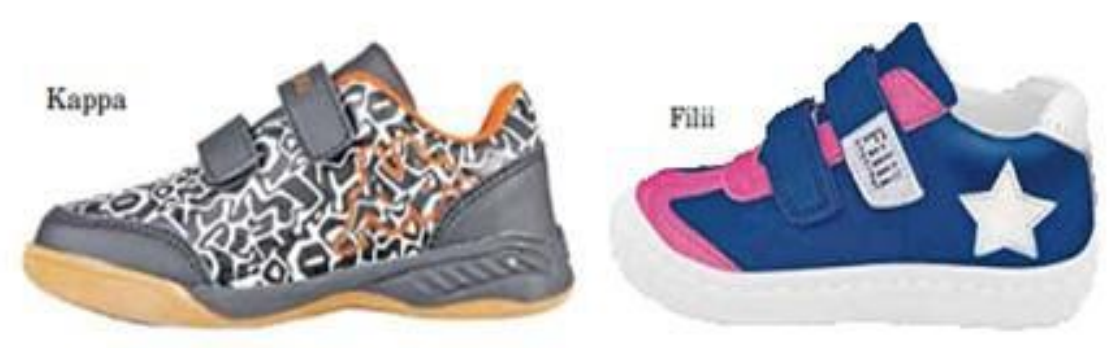

Figure 14 - Popular types and designs of shoes this year,
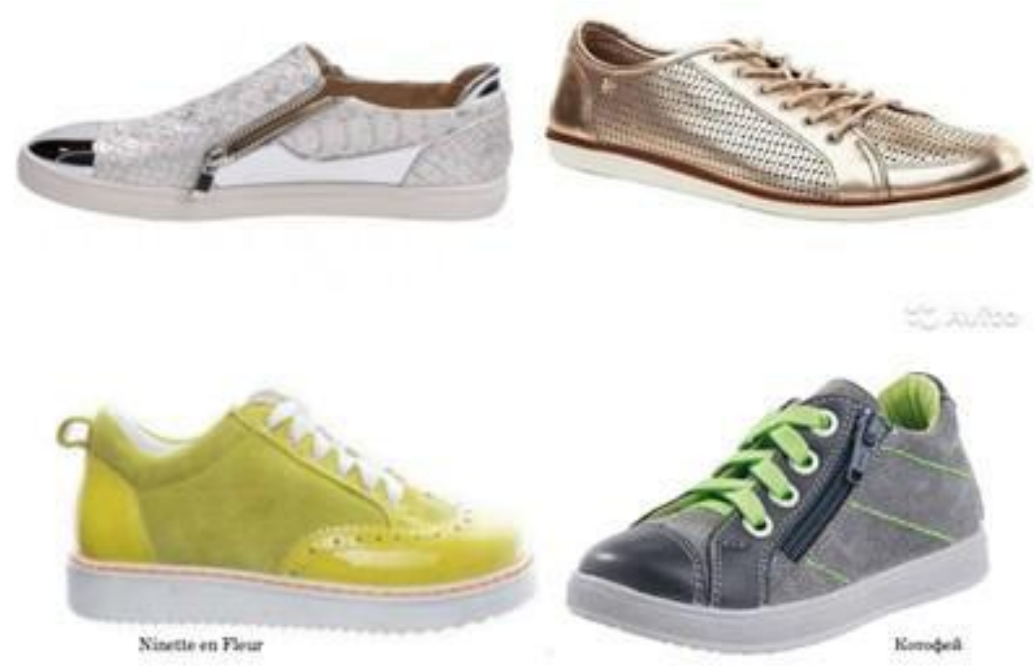

Figure 15 - Popular types and designs of this year oxfords 


\begin{tabular}{llllll} 
& ISRA (India) $=\mathbf{3 . 1 1 7}$ & SIS (USA) $=\mathbf{0 . 9 1 2}$ & ICV (Poland) & $\mathbf{= 6 . 6 3 0}$ \\
Impact Factor: & ISI (Dubai, UAE) $=\mathbf{0 . 8 2 9}$ & PUHЦ (Russia) $=\mathbf{0 . 1 5 6}$ & PIF (India) & $=\mathbf{1 . 9 4 0}$ \\
& GIF (Australia) $=\mathbf{0 . 5 6 4}$ & ESJI (KZ) & $\mathbf{8 . 7 1 6}$ & IBI (India) & $=\mathbf{4 . 2 6 0}$ \\
& JIF & $\mathbf{1 . 5 0 0}$ & SJIF (Morocco) $=\mathbf{5 . 6 6 7}$ & OAJI (USA) & $\mathbf{0 . 3 5 0}$ \\
\hline
\end{tabular}
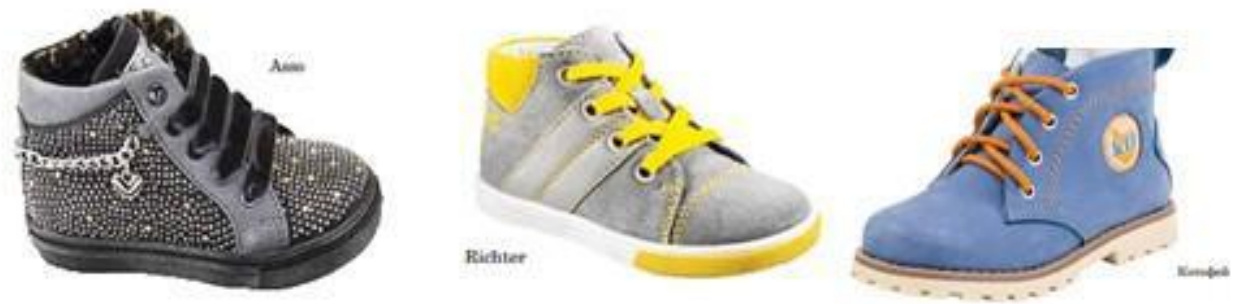

Figure 16 - Popular types and designs of shoes this year,
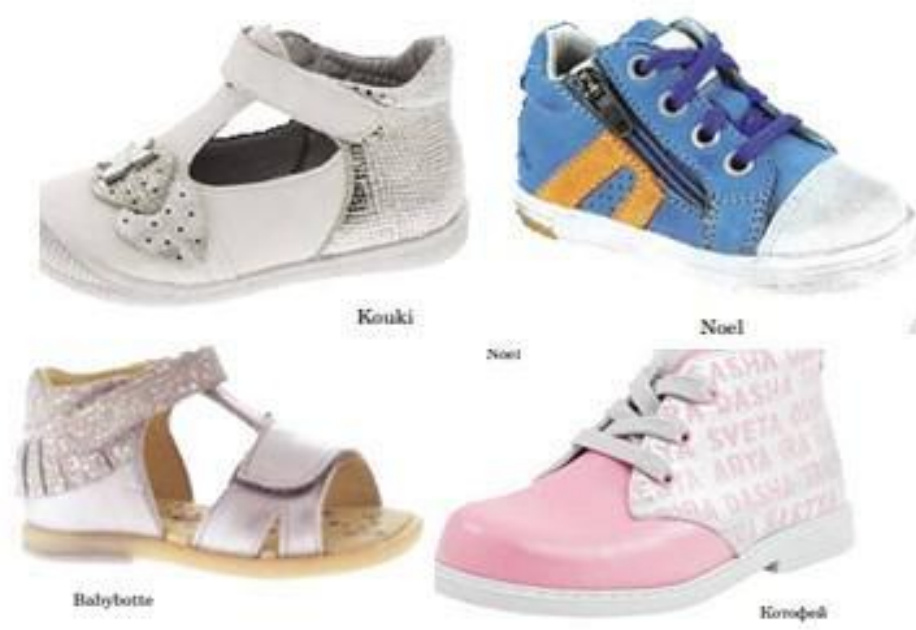

Figure 17 - Trend 2017 "Metallic and not only"
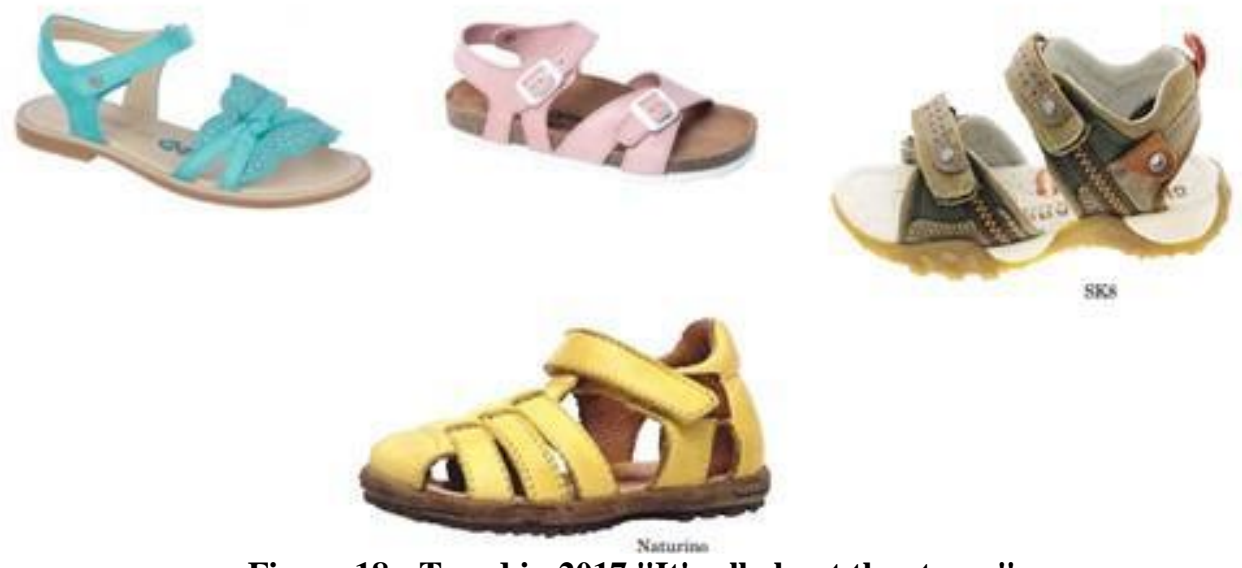

Figure 18 - Trend in 2017 "It's all about the straps"

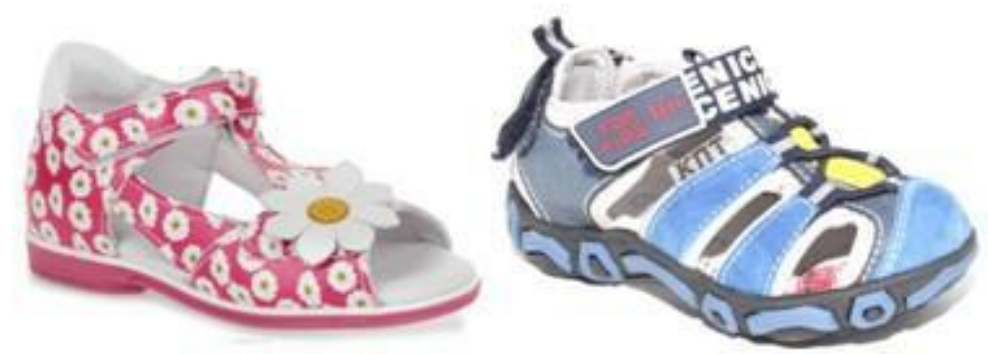

Figure 19 - Trend 2017 "Velcro comes to favorites" 


\begin{tabular}{llllll} 
& ISRA (India) $=\mathbf{3 . 1 1 7}$ & SIS (USA) & $=\mathbf{0 . 9 1 2}$ & ICV (Poland) & $=\mathbf{6 . 6 3 0}$ \\
Impact Factor: & ISI (Dubai, UAE) $=\mathbf{0 . 8 2 9}$ & PUHL (Russia) $=\mathbf{0 . 1 5 6}$ & PIF (India) & $=\mathbf{1 . 9 4 0}$ \\
& GIF (Australia) $=\mathbf{0 . 5 6 4}$ & ESJI (KZ) & $=\mathbf{8 . 7 1 6}$ & IBI (India) & $=\mathbf{4 . 2 6 0}$ \\
& JIF & $\mathbf{1 . 5 0 0}$ & SJIF (Morocco) $=\mathbf{5 . 6 6 7}$ & OAJI (USA) & $\mathbf{0 . 3 5 0}$ \\
\hline
\end{tabular}
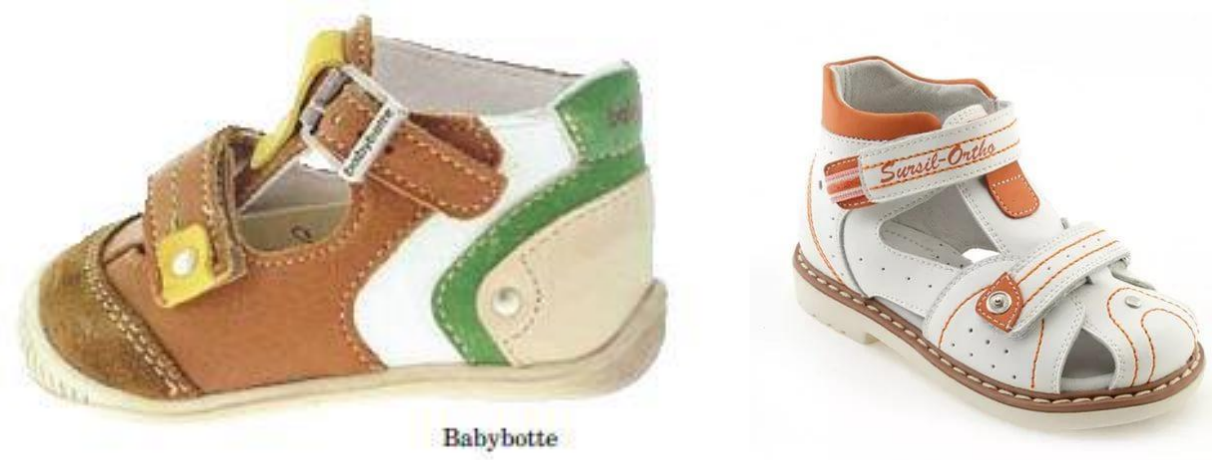

Figure 20 - Trend 2017 "in shades of soft pastels"
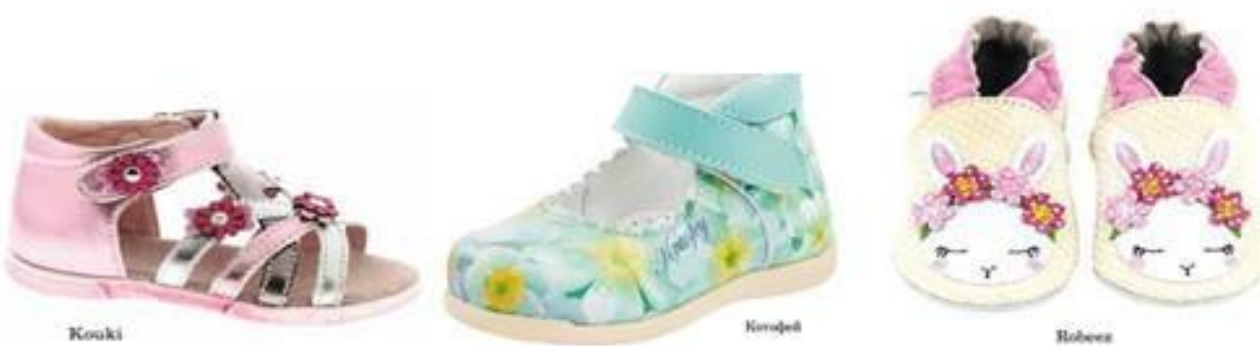

Figure 21 - Trend 2017 "in shades of soft pastels" for girls
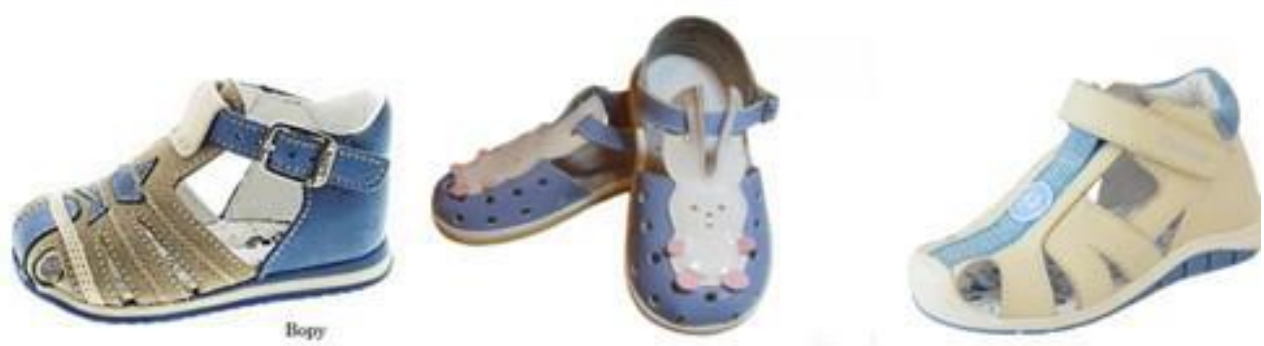

Figure 22 - Trend in 2017 "The gentle pastel shades" for boys

\section{References:}

1. Prohorov, V. T., et al. (2017). Concept import light industry: background, objectives, innovations. monograph / under the total. Ed. Dr. tehn. Sciences, prof. VT Prokhorov (Eds.). Institute of Entrepreneurship and Service sector (branch) of the Don State Technical universiteta. (p.334). Novocherkassk: Leake.

2. Prohorov, V. T., et al. (2014). Quality Revolution: quality through advertising or through real quality. monograph under the total. Ed. prof. VT Prokhorov (Eds.). ISOiP (branch) DSTU. (p.384). Novocherkassk: YURGPU (NPI).
3. Gretskaya, L. G., et al. (2012). The effect of cash flow on the performance of the cluster formed on the base of the shoe enterprises SFD and North Caucasus Federal District. under the total. Ed. prof. VT Prokhorov (Eds.). (p.354). Mines: VPO "SRSUES".

4. Vdovin, L. P., Prokhorov, V. T., Aspen, T. M., Myaleshka, E. N., \& Osatskaya, N. V. (2014). The means of achieving sustainable technical and economic performance of the shoe enterprises SFD and North Caucasus Federal District. Memory VA Fukin is dedicated: Sat. scientific. articles and vospominaniy, Part 3. (pp.32-41). Moscow: MSUDT. 


\begin{tabular}{llllll} 
& ISRA (India) $=\mathbf{3 . 1 1 7}$ & SIS (USA) & $=\mathbf{0 . 9 1 2}$ & ICV (Poland) & $=\mathbf{6 . 6 3 0}$ \\
Impact Factor: & ISI (Dubai, UAE) $=\mathbf{0 . 8 2 9}$ & PUHL (Russia) $=\mathbf{0 . 1 5 6}$ & PIF (India) & $=\mathbf{1 . 9 4 0}$ \\
& GIF (Australia) $=\mathbf{0 . 5 6 4}$ & ESJI (KZ) & $=\mathbf{8 . 7 1 6}$ & IBI (India) & $=\mathbf{4 . 2 6 0}$ \\
& JIF & $\mathbf{1 . 5 0 0}$ & SJIF (Morocco) $=\mathbf{5 . 6 6 7}$ & OAJI (USA) & $\mathbf{0 . 3 5 0}$ \\
\hline
\end{tabular}

5. Mishin, Y. D., et al. (2008). Quality Management competitive and sought-after materials and products. Monograph / under the general editorship of prof. VT Prohorova (Eds.). (p.654). Mines: Publishing House of the GOU VPO "SRSUES".

6. Prohorov, V. T, et al. (2012). Managing the production of competitive and marketable products. under the total. Ed. prof. VT Prokhorov (Eds.). VPO "SRSUES". (p.280). Novocherkassk: SRSTU (NPI).

7. Golovko, A. V., et al. (2019). On the possibilities of regulatory documents developed by the system Quality Management (QMS) for the digital production of defect-free import-substituting products. monograph / under the total. Ed. Dr. those. Sciences, prof. VT Prokhorov (Eds.). Institute of Entrepreneurship and Service sector (branch), Don State Technical University. (p.227). Novocherkassk: Leake.

8. (2018). Upravlenie quality products through the motivation of behavior of light industry enterprise team leader: monograph / under total. Ed. Dr. tehn. Sciences, prof. VT Prokhorov (Eds.). Institute of Entrepreneurship and Service sector (branch), Don State Technical University. (p.336). Novocherkassk: Leake.

9. Prohorov, V. T., et al. (2013). Sinergetika formation of a competitive range of the domestic footwear. monograph / under the total. Ed. prof. VT Prokhorov (Eds.). ISOiP (branch) DSTU. (p.194). Mines: ISOiP (branch) of Dagestan State Technical University.

10. Surovceva, O. A., et al. (2018). Management of real quality products rather than advertising through behavioral motivation of the enterprise $L$ team leaderYe with gravesoftwood industry. Monograph / under obsch.red. Dr. tehn. Sciences, prof. VT Prokhorov (Eds.). Institute of Entrepreneurship and Service sector (branch) of the Don State Technical universiteta. (p.384). Novocherkassk: YURGPU (NPI).

11. Prohorov, V. T., et al. (2018). The competitiveness of enterprises and the competitiveness of products - the key to a successful import of goods demanded by consumers The region is the Southern Federal District and the North Caucasian Federal District. Collective monograph / under the total. Ed. Dr. tehn. Sciences, prof. VT Prokhorov (Eds.). service sector and entrepreneurship Institute (branch) of the Don State Technical universiteta. (p.337). Novocherkassk: Leake.

12. Prokhorov, V. T., et al. (2015). The range and assortment policy. monograph / under the total. Ed. Dr. tehn. Sciences, prof. VT Prokhorov (Eds.). Institute of Entrepreneurship and Service sector (Phil.) Feder. state. budgets. obrazovat. postsecondary institution. prof. Education "Don State. tehn. Univ "in Mining Height. region. (ISOiP (branch) DSTU). (p.503). Novocherkassk: YURGPU (NPI). 